\title{
Austerity and Societal Response: The Double Movement in Post-Crisis Canada
}

by

Damira Grigorieva

A thesis submitted to the Faculty of Graduate and Postdoctoral Affairs in partial fulfillment of the requirements for the degree of

\author{
Master of Arts \\ in \\ Political Economy \\ Carleton University \\ Ottawa, Ontario
}

C2014, Damira Grigorieva 


\begin{abstract}
Through the application of Karl Polanyi's theory of the Double Movement and his concepts of embedded and disembedded economies, the thesis evaluates the contemporary situation in Canada post global financial crisis of 2008. Post-crisis policies and actions of the federal government in the form of financial support to financial institutions, stimulus packages and the ensuing austerity measures are evaluated alongside the societal response to these actions, which is observed through anti-austerity discourse, with special reference to the Occupy Movement across Canada and the Quebec Student Movement. As a result of the high level of neo-liberal entrenchment in Canada a strong move towards re-embedding the economy within the sphere of social influence has not been able to materialize. However, the presence of these sites of resistance represents the evidence of the Double Movement and may be the leading edge of a potential swing of the pendulum towards more socio-democratic control over the economy in the future.
\end{abstract}




\section{Acknowledgements}

First and foremost, I would like to express my sincere gratitude to my Master's thesis supervisor Prof. Allan Moscovitch for the continuous support of my study and research, for his patience, motivation, and immense knowledge. His guidance and support helped me in all the time of research and writing of this thesis.

My gratitude is further extended to the rest of my thesis committee: Prof. Randall Germain, Dr. Roy Culpeper and Prof. Laura MacDonald for their encouragement, insightful comments, and hard questions.

I would like to thank Prof. Manfred Bienefeld, whose enthusiastic teaching inspired me to concentrate my research within the framework of Karl Polanyi's theories.

My sincere thanks also go to my managers through the four years of my Master's degree: Vic Charest, Martine Belanger, Diane Hall and Nancy Brunet. Their willingness to support my academic efforts greatly contributed to the achievement of this accomplishment.

Last but not least, I would like to thank my loved ones: family, friends, and beloved husband Ruslan Kedik. They have supported me throughout the entire process by keeping me focused, harmonious and motivated to realize my potential. 


\section{Table of Contents}

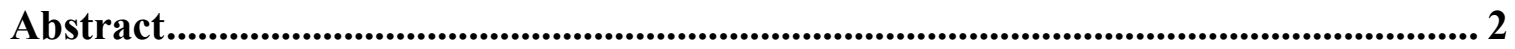

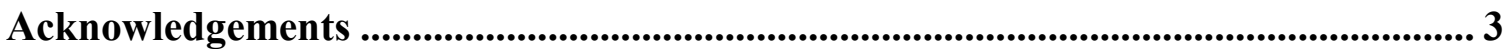

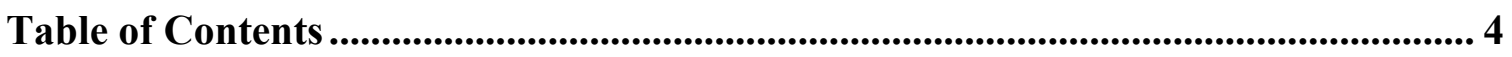

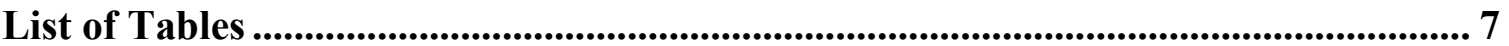

1 Chapter: Introduction and Background........................................................................ 8

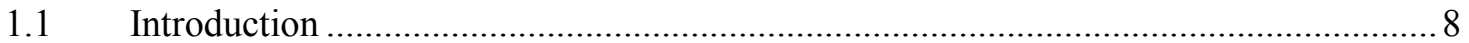

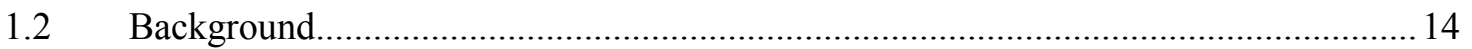

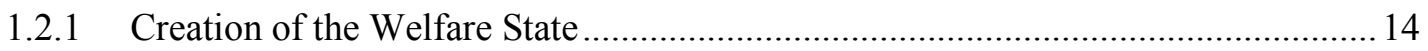

1.2.2 The Development of the Welfare State in Canada ................................................... 17

1.2.2.1 The Value of the Social System in Canada ................................................... 19

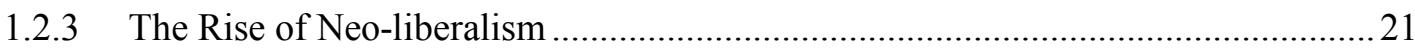

1.2.4 The Evolution of Canada's Neo-liberal Environment...........................................27

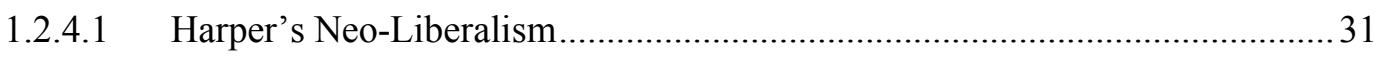

1.2.4.2 Statistical Evidence of the Rise of Neo-Liberalism...........................................33

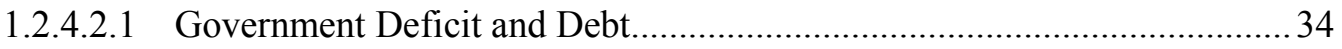

1.2.4.2.2 Government Expenditures and Revenues and Government Social

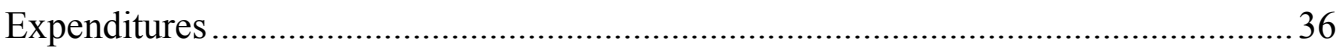

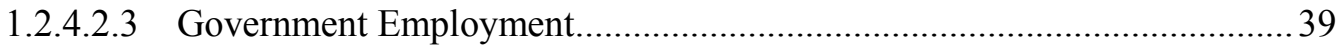

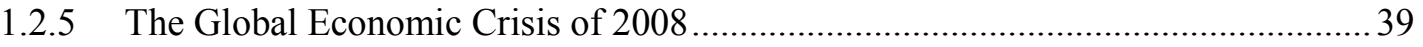

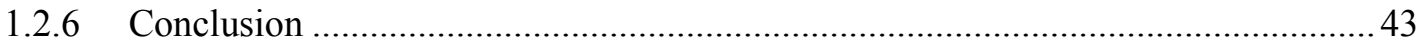

2 Chapter: Karl Polanyi's Theory of the Double Movement...................................... 44

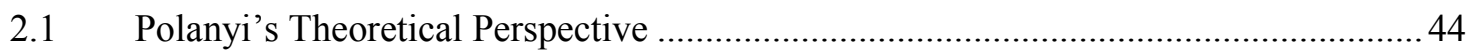

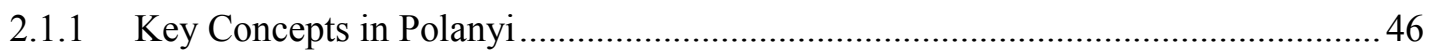

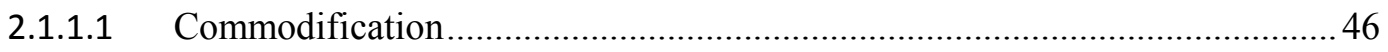




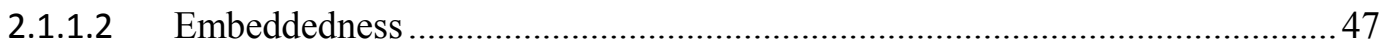

2.1.1.3 Economic Fallacy and Stark Utopia ............................................................ 50

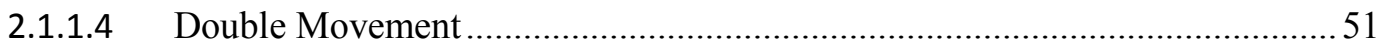

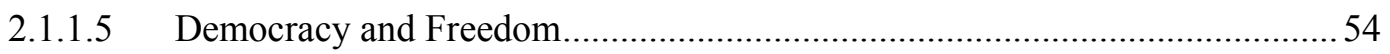

2.2 The Use of Polanyi's Thought by Other Theorists .................................................. 56

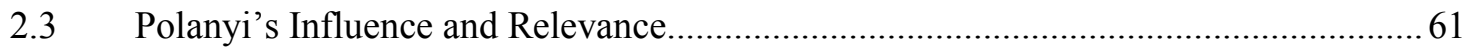

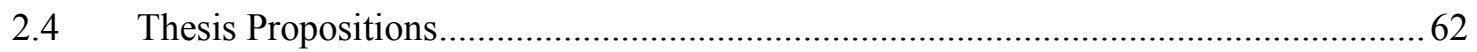

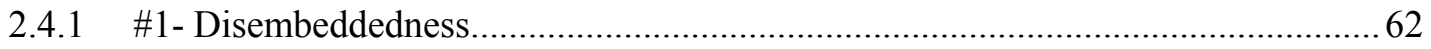

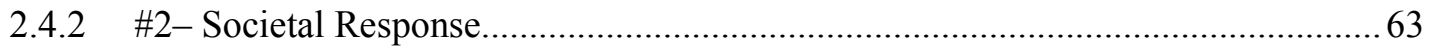

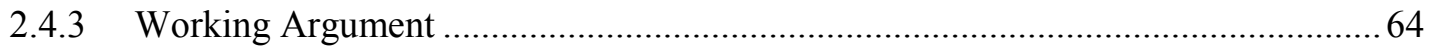

\section{Chapter: The Economic Crisis of the 21st Century: Disembedding the Economy} from Society .................................................................................................................................. 65

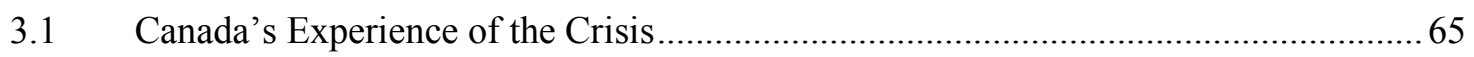

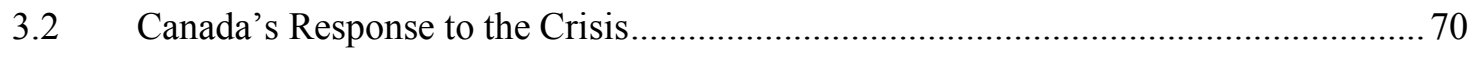

3.2.1 Financial Support to Financial Institutions and Stimulus Measures ........................ 70

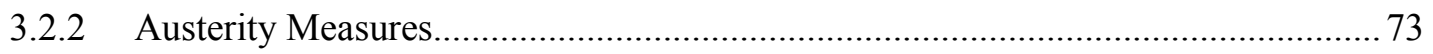

3.3 Budgets as the Implementation of Neo-liberalism .............................................. 76

3.3.1 Financial Support to Financial Institutions and Stimulus Measures ........................ 76

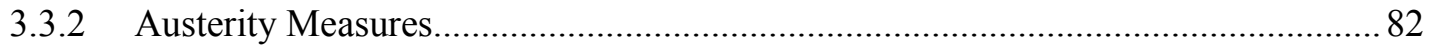

3.4 Disembeddedness: Analysis of the Response to the Crisis, 2008-2013 …................. 89

3.4.1 Financial Support to Financial Institutions and Stimulus Measures ........................90

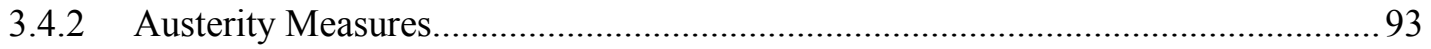

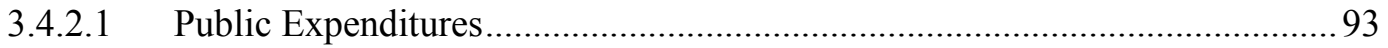

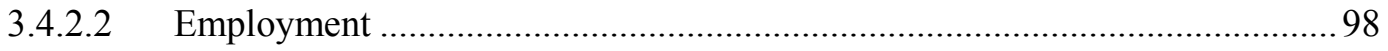

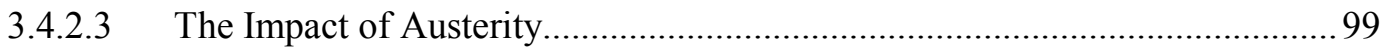

3.4.2.4 The Impact of Austerity on Democracy …................................................ 100 


\section{Chapter: Societal Response to Austerity: an Attempt to Re-Embed the Economy} within Society ................................................................................................................ 104

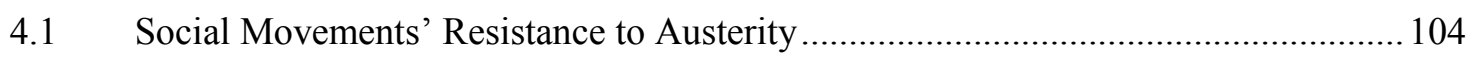

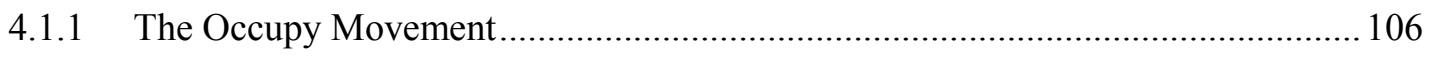

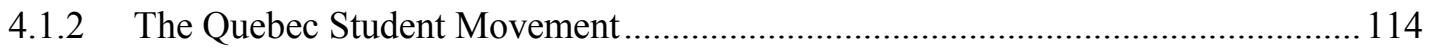

4.2 Facebook Content as Expression of Societal Resistance......................................... 119

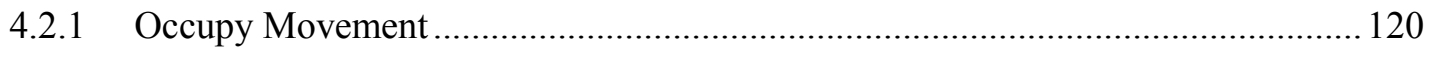

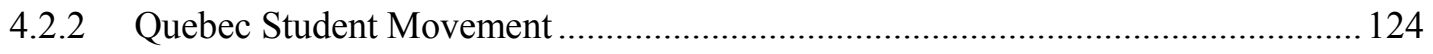

4.3 Embeddedness: Analysis of Societal Resistance, 2011-2014_................................ 127

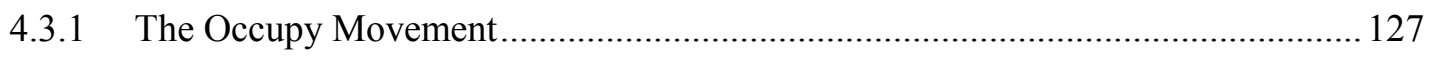

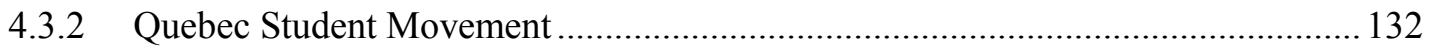

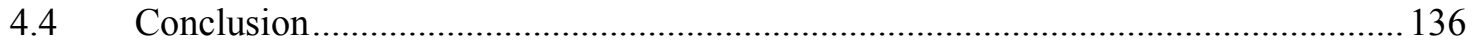

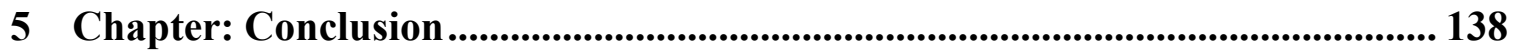

Bibliography or References................................................................................................... 143 


\section{List of Tables}

Table 1 Federal Budgetary Surplus of Deficit, 1966-67 to 2012-13 (percentage of GDP)

Table 2 Federal government, total direct and indirect debt, less sinking funds, by type,

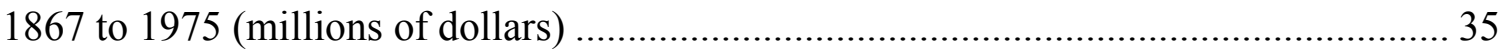

Table 3 Federal Government Accumulated Deficit (i.e. Federal Debt), 1966-67 to 2012-

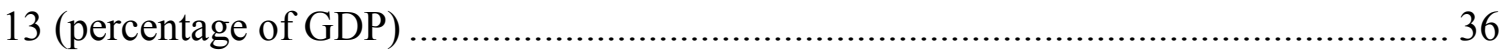

Table 4 Federal government budgetary revenues and expenditures, 1867 to 1975 (millions of dollars).

Table 5 Federal government budgetary revenue and expenditure, 1966-67 to 2012-13

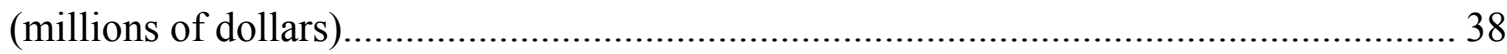

Table 6 Federal government budgetary revenue and expenditure, 1966-67 to 2012-13

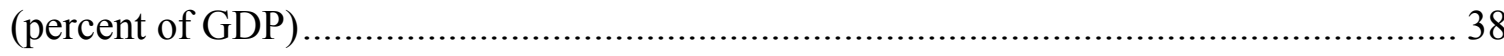

Table 7 Compensation of employees paid by government, 1981 to 2012 (percentage of

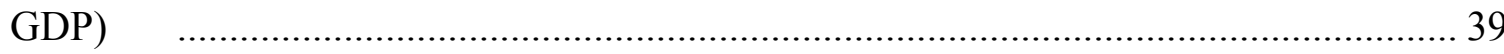

Table 8 Gross Domestic Product of Canada, 2000-01 to 2012-13 (millions of dollars) 67 Table 11 Canada's Economic Action Plan - Results Achieved, 2009-10 to 2011-12

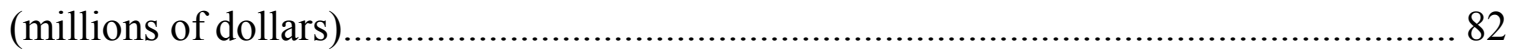

Table 12 Strategic Reviews - First Four-Year Cycle, 2008-09 to 2014-15 (millions of

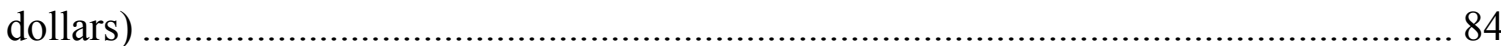

Table 13 Planned Reductions in Departmental Spending, 2012-13 to 2014-15 and

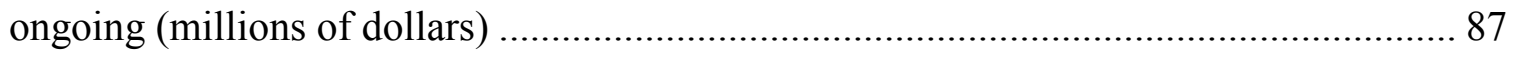

Table 14 Budget 2012 Ongoing Savings by Sector (thousands of dollars) ................ 98 


\section{Chapter: Introduction and Background}

\subsection{Introduction}

In the post-1970s, neo-liberalism became the dominant ideology of the major industrial countries and the international economic institutions which they control, systematically pushing the post-World War II era of the welfare state out of the scope of international politics. Under neo-liberalism, commodification, the market, and concepts of supply and demand take precedence over state regulation and active government involvement in markets. This premise is based primordially on economic laissez-faire principles of competition and efficiency; social factors are thus moved to the background of decision-making. Forces of globalization are expressed through global governance and the powerful international institutions such as the G7, the G20, the IMF, and the World Bank, which put the neoliberal regime into practice and ensure that its spread is extended across the globe. Through the rise of the market economy, the functioning of most industrial societies in the world is now predicated on financial sectors and institutions. With deregulation, market forces in financial spheres have led to a rapid expansion of credit and debt leading to greater financial dependency of the economy and society on these market mechanisms (Thomasberger, 2012). Dependency on financial sectors is not only expressed at the macro state level, it is also witnessed at the citizenry and household levels with the expansion of access to credit. The promises of homeownership and increased standards of living were achieved not through the increase of real wages, but through the accumulation of debt (Herman, 2012). Thus the move 
away from welfare state provisions is legitimized by the substitution of real growth with the reliance on greater credit provisioning.

In 2008, the world experienced quite prominently the inability of deregulated markets to exist in a state of perpetual stability and prosperity. While many say that Canada largely avoided the global economic crisis of 2008 and that its impacts were minimal (Roberge, 2010), one cannot refute the fact that the aftershock of the crisis was present. Through interconnectedness, the forces of globalization and the prevalence of a federal neo-liberal economic regime, Canada, as did most countries around the world, experienced the shock stemming from the failure of financial markets in the United States and Europe. Recession in Canada took place between late 2008 and mid-2009, and while being in a recession for less than a year may not seem like a prolonged amount of time, the damage to the economy was significant and irrefutable (Campbell B., 2009).

With the spread of the economic downturn, the Canadian government took drastic measures by providing financial support to financial institutions (da Silva, 2009) as well as an extensive stimulus package to uphold economic growth (Department of Finance, The Stimulus Phase of Canada's Economic Action Plan, 2012). This resulted in an increased expenditure on the part of the state, augmenting the government's fiscal deficit. As is the current situation in Europe and the United States, Canada is now undertaking austerity measures to bring the country's deficit back to a favourable position or what is often referred to as 'balancing the books' over the medium term (Department of Finance, Jobs Growth and Long-Term Prosperity, 2012). The Oxford dictionary defines austerity as "difficult economic conditions created by government measures to reduce public expenditure" (Oxforddictionaries.com, 2014). The austerity measures in Canada that 
have been implemented in the post-crisis environment have hindered the delivery of the country's safety net benefits and have curtailed the stability of the public sector.

Despite being an economically unsound option, austerity is the popular route for many industrialized nations in the post-crisis scenario because it provides an avenue for further neo-liberal entrenchment resulting in the scaling back of the welfare state and public services in general. Changes of this magnitude however do not go unnoticed and societal forces play a crucial role. The country has witnessed a societal response and retaliation to the changes being imposed on the population by austerity measures. Massive demonstrations against hikes of post-secondary education tuition fees were held in Quebec in 2012, spreading to thousands of participants and spanning more than one hundred days. In 2011, the Occupy Movement, which first manifested on Wall Street in New York City, spread to more than 80 countries around the world, including more than 20 Canadian municipalities. The movement was primarily targeted at the financial sector of the economy and the richest 1 percent of the population, but turned into a more general anti-austerity manifestation against the injustices of our social and economic order. While the response of the Canadian population may not be as great as in some of the countries in Europe, where the recession was far worse, the degree of austerity far greater, and demonstrations were heavily felt, regardless of the scale and magnitude, Canadians were not standing idly by. Civil society's participants in Canada are active in terms of democratic forces and they do indeed have an impact on the decision making in the country. This thesis will explore the extent to which civil society has had material manifestations in the past several years in Canada. 
Writing in the tumultuous times of pre-World War II Europe, Karl Polanyi's The Great Transformation captures the rise of the market economy as it occurred in the late eighteenth to early nineteenth centuries. Polanyi tried to expose the fact that laissez-faire markets are inherently problematic because they function purely on economic principles and discount societal needs and preferences. Polanyi claimed that this disregard created what he referred to as disembedded markets, where the market economy functions on principles of fictitious commodities. For Polanyi this meant that labour, land and money are fictitious, in the sense that while they are commodities, only some of their qualities could be captured in and through markets. Polanyi saw the disembedded market leading to an inevitable collapse and social/political unrest. In his view, the unrestricted market will inevitably be affected by the pressure of self-protection or self-preservation of society from the harmful effects of unrestrained economic forces. The Double Movement represents a growing deregulation of economic forces on the one hand and a societal response of curtailing these market forces on the other. In other words, the Double Movement is a simultaneous and mutually reactive set of forces from the disembedded market economy to societal response and from embedded market to social reaction. Polanyi's theories allow for an examination of pendulum forces of regulation and deregulation (Castles, Cubas, Kim, Koleth, Ozkul and Williamson, 2011).

Polanyi's concepts of embeddedness and disembeddedness play a central role in this work to explain the evolution from the welfare state, where priority of the government is ensuring protection and promotion of economic and social well-being of its citizens, to the neo-liberal state where self-regulation and minimal interference from the state is valued most. An embedded economy is one in which economic activity is 
integrally connected to social relations, and socio-democratic forces have a say in the functioning of the economy through institutional regulation. Greater distribution of wealth and the provision of social services characterize this type of economy. In the contemporary historical period, the decades following WWII saw most prominently the rise and stabilization of an embedded economy. While in recent years embeddedness is still present, since the 1970 s it is systematically being replaced with a more disembedded framework of state functioning. In this realm, a greater degree of separation is present between the economic and the socio-democratic spheres. State actions are more inclined to side with corporate interests rather than support of the general society, relying on the ‘trickle-down' effect of societal wealth building as opposed to mutual support and obligation to those less fortunate. The rise and growth of neo-liberalism leads to disembeddedness of the economy from societal forces.

Using Polanyi's theoretical framework of the Double Movement, this thesis will examine the crisis of 2007-08 and the period of post-crisis austerity and society's attitudes towards it in Canada. The Double Movement represents the pendular swing of the political-socio-economic environment of embeddedness or disembeddedness of the market from society. The policies and actions of the federal government (not discounting that provincial and local governments embarked on the same approach) will be analyzed and the financial support to the financial sector, the stimulus package and the ensuing austerity measures will also be examined. Societal attitudes will be observed through anti-austerity discourse and through resistance to austerity, with special reference to the Occupy Movement across Canada and the student protests in Quebec. 
This thesis will argue that Canada is continuously undergoing the disembedding of the economy from the socio-democratic sphere of influence in the framework of neoliberalism. The economic crisis in Canada and the resulting government actions have in turn set in motion a societal response that may someday be successful in changing attitudes towards neo-liberalism and lead towards a more embedded approach to economic regulation than witnessed in recent decades. However, since the current paradigm of neo-liberalism and disembeddedness is so highly entrenched in the lives of Canadians, the pendular swing of the Double Movement re-embedding the market within the sphere of influence of society will likely not be successful. Nonetheless, what Polanyi's approach suggests is that the social response to the 2008 crisis and the austerity that has followed may be the leading edge of a movement away from disembedded markets. 


\subsection{Background}

At the core of political economy is the relationship of markets and society. What Polanyi suggests is that there are ever-present tensions between the two acting in a pendulum fashion.

The current neo-liberal paradigm experienced on a global scale as the predominant and hegemonic ideas in the world order became prominent in the 1980s. To fully understand the paradigm, it would be worth evaluating its metamorphosis further back in history. The origins of the paradigm can be traced back to the United Kingdom and the United States at the end of the nineteenth and throughout the twentieth centuries as these two countries drove Canada's own manifestation of the market-society relationship through colonial ties and hegemonic discourse of capital dominance. The UK was particularly influential in the period before World War II, with the sphere of influence shifting to the US thereafter. While the paper generally refers to Canada as the main focus of the analysis, the UK, the US, and the global environment at large set the stage for the Canadian example.

\subsubsection{Creation of the Welfare State}

An appropriate place to start is the market crash of 1929 and the Great Depression of the 1930s, which was the most widespread, deepest, and harshest depression in the history of capitalism. "The self-regulating market system, freed from all control, failed to provide jobs and bread for working people and caused social and cultural disintegration in their midst (Baum, 1996, p. 53).” According to Labonté (2012), the pre-crash era was marked by corporate concentration, market power, and extreme wealth gathering. The 
Great Depression brought about massive unemployment, plummeting stock prices and declines in production; it also prompted a higher degree of protectionism which was set aside only as the result of the engagement of most industrialized countries in World War II. The politico-economic thought that preceded this period in history was classical liberalism of laissez-faire, a variant of the liberalism which originated with Adam Smith's theories, prominent at the beginning of the Industrial Revolution in the United Kingdom. In the period during and following the Great Depression, a debate arose about the relationship between the market and the state. On the one hand, the trade-off hypothesis "pitted efficient markets against the inefficient state, and economic efficiency against inefficient social protection" on the other hand, a complementary hypothesis claimed that "state interventions were necessary to ensure economic stability and social protection (Pitruzello, 2004, p. 709)." It took another event of massive hardships - World War II - to skew the debate towards the complementary hypothesis, bringing social liberalism to the forefront.

One of the most prominent thinkers in the realm of social liberalism was John Maynard Keynes. While Keynes was fundamentally pro-market, he strongly believed in respect for rules and regulations in order to curtail excess. "Keynes rejected the neoliberal credo and defended the virtues of regulated markets, budgetary deficit spending, and the ‘socialization of investment' (Seccareccia, 2013, p. 3).” According to Keynesian principles, capitalism needed to be managed at the national level, and government spending and taxes needed to be countercyclical (at times of recession, demand is stimulated through increased spending and decreased taxation) to ensure growth and stability and to reduce the social impacts of recessions. As per Polanyi-Levitt (2012), the 
postwar period dictated an informal social contract in which the goal of the state was to provide for full employment, accompanied by price stability and the reduction of income inequality. In the UK, "the Churchill government commissioned William Beveridge to produce a plan for social security from cradle to grave (Polanyi-Levitt, 2012, p. 8).” Beveridge utilized Keynesian principles in writing his report Social and Allied Services, which was published in December 1942, outlining the social and health programs that should be provided by the state (Jones, 2012).

Another prominent component that characterized the time of the pendulum swing towards state programs and regulations was the realization of collective bargaining on the part of labour. Workers were allowed to negotiate higher wages, which translated into growth and improved standards of living. In the UK, as unions became central in contributing to the war effort between 1939 and 1945, the state was obliged to honour the social contract by providing workers with more favourable working conditions as well as social services outside the workplace. The power of the unions and the rising welfare state went hand in hand in the period of history following the Great Depression and WWII (Chaves, 2012).

The post WWII period has been described as the Keynesian era, a time marked by social liberalism, democratic capitalism, and the welfare state, in which the pendulum of state intervention was inclined towards protecting the well-being and rights of citizens. The postwar era is appropriately summarized by Baum (1996, p. 53):

"During the decades after the Second World War, conditions changed for the better. Governments assumed greater responsibility for the well-being of their people. Pushed by the labour movement and social-democratic parties and guided by Keynesian economic principles, governments played an active role in revitalizing national economies and redistributing, through various social welfare measures, some of the wealth produced. The new state of affairs was marked by an unwritten 
contract between capitalist society and the working class guaranteeing full employment, social welfare, and respect for labour unions."

The manifestation of the welfare state in a post-World War II period was an allencompassing movement, the reach of which was broad such as to affect most industrial countries to a large degree in the postwar era of reconstruction. The development of the welfare state in the post-depression and post-war environment is clear evidence of the Polanyian pendulum swing towards the embeddedness of the economy in societal forces, a society based on redistribution, social protection, and full employment.

\subsubsection{The Development of the Welfare State in Canada}

As in the United Kingdom and subsequently throughout much of the industrialized world, Canada embarked on the development of its welfare state. The previously mentioned Beveridge report influenced the development of a similar report in Canada. The Report on Social Security for Canada was commissioned by the Prime Minister in December of 1942, and published in March 1943. Written by Leonard Marsh, it laid out a blueprint for universal social programs and services. This publication was followed by the publication of the White Paper on Employment and Income in 1945, drafted by W.A. Mackintosh, a disciple of Keynes. It set the stage for the adaptation of Keynesian policies to Canada (Guest, 1997). These publications paved the way for the eventual development of a welfare state in Canada. While some social provisions were already in place, the next few decades saw major growth in these programs through their institutionalization and liberalization (Battle, 1998).

Unemployment Insurance was first legislated in 1940 to support workers who have lost their jobs through no fault of their own. In 1956 the Unemployment Assistance 
Act was put in place further solidifying the provision of support to workers. A universal Family Allowance followed the war in 1945, providing financial assistance to families with children under the age of 16 . The next universal program that was established was Old Age Security in 1951, providing a pension to anyone over the age of 70 . In the meantime, plans were taking shape in support of health provision, education, housing provision, support for the disabled, etc (Graham, Karen, Roger, 2003; Guest, 1997).

In the period from 1963 to 1968 , much of the contemporary welfare state was established under a Liberal minority government led by Lester Pearson and supported by the newly established New Democratic Party. It was the era of fiscal federalism in which the federal government took the lead in the development of what was otherwise under the authority of the provincial governments: social welfare. The universal health system took a while longer to develop and was established federally in 1966. The Canada Assistance Plan (CAP) was also established in 1966 as a federal cost sharing program with provincial governments in the provision of assistance and welfare services. That same year two more programs were introduced federally to support Canadians in the later stages of life. The Canada Pension Plan (CPP) provided retirement benefits in proportion to workplace earnings while the Guaranteed Income Supplement (GIS) acted as a supplement to OAS and CPP for low-income earners. Lastly, medicare, universal health insurance was introduced in 1968 (Graham, Karen, Roger, 2003; Guest, 1997).

Once the establishment of these programs took place, further changes were made to increase and solidify their impact. In 1971, the Unemployment Insurance program was considerably expanded, with increased benefit rates and was eventually extended to offer 
sickness and maternity benefits as well. The CPP and OAS programs were also expanded, raising benefit rates and extending to surviving spouses respectively. Family Allowances were tripled and indexed in 1973 (Graham, Karen, Roger, 2003; Guest, 1997).

The period of the 1970s can be characterized as one of movements in both directions: embedding of new programs, disembedding of old ones. This goes hand in hand with the beginning of the rise of a new social order - neo-liberalism, which aimed to dismantle social services provisioning by gradually reducing the scope and breadth of assistance.

\subsubsection{The Value of the Social System in Canada}

In Canada, issues concerning the social system are central to most citizens, many of whom in fact associate their national identity with the once-universalist welfare state. Healthcare, education, employment assistance, pensions, etc. are all part of what defines Canada as a generous land with a high standard of living. However, with the rise of neoliberalism, the social system of the welfare state has come under great scrutiny and debate. Typically, the defenders of the welfare state are found among social advocates, anti-poverty groups, labour, women's groups, the New Democratic Party and the academic left. On the other hand, right wing organizations and Conservative governments as well as the corporate sector are often opposed to certain social services, using arguments that the programs exacerbate the issues they are meant to solve and expand the size and scope of the state. Another obstacle to social programs in the general 
population is its experience of tax fatigue, especially in the rising culture of the individualistic and self-proprietary neo-liberal discourse.

Despite opposing views on Canada's social system, we must consider the great value social services bring to the lives of many. One cannot go a day without encountering a public service of some nature. From the daily commute, to the proper workings of the sewer system, to the schools attended by children, youth, and adults alike, public services of which social welfare programs are a major constituent, touch many aspects of modern life.

In terms of the value for money aspect, public services are a reciprocal investment that makes use of tax dollars to provide value to Canadians. Bourgeois, Hussey, Saulnier, and Wuite (2012, p. 11) state that "more than two-thirds of Canadians derive a benefit from the public sphere that is greater than half their income." Another author (Mehra, 2012) places the value of use of Canadian publicly funded programs and services at $\$ 41,000$ per year for an average household and $\$ 17,000$ for an individual. This notion is especially important for the lowest earning 20 percent of Canadian households, for whom public services increase consumption possibilities by more than 100 percent.

Apart from the financial value, social services increase standards of living through improved health and longevity, greater educational attainment and training opportunities, support in an event of income loss, etc. Cutting of funding for these programs deteriorates the lives of many individuals and families reliant on social benefits to complement the income earned through the market. Moreover, public services support and strengthen democratic society. With the distribution of income through taxation and 
creation of social programs, Canada maintains a socially and economically just society (Bourgeois, Hussey, Saulnier, and Wuite, 2012).

The next section of the text will examine the transformation of social services through the neo-liberal age throughout industrial nations and particularly in Canada. The period in question spans from the mid-1970s and beyond and is characterized by a move away from the nation state structure towards a state that is market oriented (Baum 1996).

\subsubsection{The Rise of Neo-liberalism}

At the same time as Keynes' economic prescriptions of the welfare state were being embraced, an Austrian-born thinker, Friedrich Hayek, was conceiving of the notion of neo-liberalism as an antidote to the 'collective' politics of regulated markets. Hayek is attributed with the 'reviving of liberalism and capitalism' and pro-market thinking through the publication of his book in 1944, "The Road to Serfdom", and the creation of the Mont Pelèrin Society in 1947 along with a fellow economist Ludwig von Mises. He was adamantly against central planning as he envisioned this scenario inevitably imposing on individual rights and freedoms, thus leading to servitude. While Hayek did not proclaim the end of social spending, he envisioned state action as circumscribed to preserving the rule of law, and allowing the free market society to flourish. The Mont Pelèrin Society created a 'transatlantic neo-liberal movement' by formalizing and concentrating the efforts of global neo-liberal thinkers. While starting off with only 39 members, the ideology became mainstream through the founding of think tanks, then through journalists and conservative media, and politicians (Filip, 2012; Jones, 2012; Valderrama, 2012). An Economist article (The Birth of Neoliberalism, 2012) reviewing 
Daniel Stedman Jones' book Masters of the Universe stresses that the "think-tanks were the most important. With lectures and publications, they propagated ideas frowned upon at universities and converted the most powerful players in this revolution. Margaret Thatcher and Ronald Reagan counted themselves as inspired visitors." Milton Friedman is considered the major influencing actor in implementing neo-liberal policies in the United States, whose most influential work was his 1951 paper, entitled "Neoliberalism and Its Prospects" (Jones, 2012).

The postwar era was marked by an accelerated growth in industry, manufacturing, and output. However, such gigantic leaps in industrialized progress, tremendous improvements in standards of living, and increased rights of the workers could not be sustained. As growth began to slow down, the state was still invested in ensuring full employment in line with the Keynesian model.

"When growth began to falter in the late 1960s, however, this combination became difficult to maintain. While free collective bargaining enabled workers through their unions to act on what had become firmly ingrained expectations of regular yearly wage increases, governments' commitment to full employment, together with a growing welfare state, protected unions from potential employment losses caused by wage settlements in excess of productivity growth. Government policy thus leveraged the bargaining power of trade unions beyond what a free labour market would have sustained (Streeck, 2011, p. 11).”

The byproduct of this phenomenon was increasing inflationary pressures and once those were no longer sustainable, the state started accumulating public debt to close the gap between the demands of the workers and the productive capacity of the market. In the 1970s the period of stalled growth and increased inflation, exacerbated by the OPEC oil crisis, resulted in stagflation (Chaves, 2012). At this time, neo-liberal thinkers, such as Friedrich Hayek in the United Kingdom and Milton Friedman in the United States, were perfectly positioned to step in to influence the policy direction away from the 
maintenance of the social system and the welfare state and towards the liberalization of the market.

The US President Ronald Reagan and the UK Prime Minister Margaret Thatcher are the political leaders most credited with the turn of the policy prescription towards the market in the industrialized world. "When Ronald Reagan and Margaret Thatcher, with support from the capitalist elite, abandoned the Keynesian capitalism that had prevailed since the Second World War and adopted monetarist economic policies, the economy gradually returned to the practices of the self-regulating market system, this time on a global scale. As a result, society has experienced profound transformations (Baum, 1996, p. 40)." The policies implemented at the time have been getting progressively implemented into the political-economic systems around the world.

One of the most prominent current theorists and critics of neo-liberalism, David Harvey (2005, p. 2), proposes the following definition:

"Neoliberalism is in the first instance a theory of political economic practices that proposes that human well-being can best be advanced by liberating individual entrepreneurial freedoms and skills within an institutional framework characterized by strong private property rights, free markets and free trade. The role of the state is to create and preserve an institutional framework appropriate to such practices. The state has to guarantee, for example, the quality and integrity of money. It must also set up those military, defence, police and legal structures and functions required to secure private property rights and to guarantee, by force if need be, the proper functioning of markets. Furthermore, if markets do not exist (in areas such as land, water, education, health care, social security, or environmental pollution) then they must be created, by state action if necessary. But beyond these tasks the state should not venture. State interventions in markets (once created) must be kept to a bare minimum because, according to the theory, the state cannot possibly possess enough information to second-guess market signals (prices) and because powerful interest groups will inevitably distort and bias state interventions (particularly in democracies) for their own benefit."

Neo-liberalism is further characterized by the following key components:

encouragement of the self-regulating market, monetarist policies, increased 
financialization, promotion of global competition, deterioration of the autonomy of the state. Neo-liberalism favours the small and efficient state, elimination of government debt, privatization of state functions, deregulation, and reduced taxation. At times this is referred to as the corporate state as opposed to the state that plays a large role in a country's economic situation - the welfare state. These principles are solidified in the Washington Consensus. Williamson (1990) laid out the 10 features of economic policy on which Washington technocrats have convergence. These are embodied by fiscal discipline or a preference for smaller deficits; public expenditure priorities aimed towards pro-growth, pro-poor services and provisions in the areas of health, education and infrastructure, eliminating non-merit subsidies; tax reform which is viewed as an inferior alternative to raising public revenue (the superior alternative is managing public expenditure priorities); liberalizing interest rates and establishing competitive exchange rates; liberalization of trade and foreign direct investment; privatization with the belief that private industry is managed more efficiently than the public one; deregulation as a way of promoting competition and creating efficiency; and property rights. Having gained assent from the elite and capital holders, neo-liberalism became the hegemonic global social order towards which every country (with a few exceptions such as Venezuela under Chavez) was striving (Thomasberger, 2012).

"Corporations adopted strategies that allowed continual capital accumulation by lowering production costs (technology and outsourcing), opening new markets (reduced border barriers) and increasing the financialization (Labonté, 2012, p. 258).” By embarking on this restructuring, the continuation of growth was secured, but growth came at the expense of the deterioration of stability, security, and standards of living for 
the middle, working classes, and for the poor. Thinkers such as David Harvey and Gareth Dale refer to the neo-liberalist retrenchment of the welfare state as a class project. Harvey (in Dale, 2012, p. 17) has argued that "the free market utopia that ostensibly defines neoliberalism in fact functions as ideological cover for a 'class project': the drive to restore corporate profit rates at the expense of workers and welfare recipients." Colatrella (2011, p. 82) sees neo-liberalism as a "project for overcoming the political, economic and cultural differences that divide elites in countries around the world." In his opinion the state is broken down into institutions that favour certain class constituencies in society. Neo-liberalism tries to reorganize the state in a way as to gear it towards more capitalist interests. This is happening more and more with witnessing the growth and prosperity of the neo-liberal age concentrating the profits in the hands of the holders of capital. A result of this phenomenon is a sharp increase in inequality (Colatrella, 2011).

The hegemonic American empire serves as an example of rampant inequality. Between the years 1979 and 2007, the incomes of the richest 1 percent of the United States' population increased by 275 percent, while the incomes of the middle 60 percent of the population rose only by 40 percent. What is even more devastating is that the income of the poorest 20 percent rose only by 18 percent. The 400 richest people in the country control more wealth than the bottom 50 percent of households. The level of poverty is another devastating statistic. According to the U.S. Census in 2010, 46.9 million people lived in poverty, up from 37.3 million in 2007-the fourth consecutive annual increase in the number of people in poverty. This statistic registered the highest number in poverty in the 52 years of its existence (Campbell, 2012). In Canada, the results are similarly bleak. Between 1998 and 2007, the richest one percent took home 
almost a third of all growth in incomes. This increase in inequality "can be attributed to institutional forces, like declines in unionization rates, stagnating minimum wage rates, deregulation, and national policies that favour the wealthy. In Canada, Yalnizyan notes that falling top marginal tax rates are part of the explanation for the rise of the richest 1 per cent of the population (The Conference Board of Canada, 2014)."

In terms of the effects neo-liberalism has had on democracy in industrialized states, the situation is presently bleak. While most democratic rights, such as free assembly and voting have been left untouched, the meaning and power they carry has been altered dramatically. According to Streeck (2011), economic power now carries more weight than it once did and its ability to influence policy and government has been growing over the years. Not only is the public sector shrinking and offering less to its citizens, the whole notion of citizenship and democracy is continually under attack, with citizens having fewer opportunities to make their interests and demands heard at the decision making level. The neo-liberal era has subjected the state to economic and capital control verses democratic control. Instead of tailoring to the demands of the citizens, states try to please capital holders. Streeck (2011, p. 26) says that "the markets have begun to dictate in unprecedented ways what presumably sovereign and democratic states may still do for their citizens".

Chaves (2012, p. 117) provides a summary of how historical events and the changing nature of the relationship between the market, society and the state led up to the economic crisis of 2008:

"The welfare state provided labor with the right to collectively bargain, allowing them to negotiate a higher wage. By also guaranteeing full employment, in keeping with the Keynesian model then adopted, the state leveraged labor's bargaining 
power. As growth began to stall, the government continued to protect employment, with rising inflation as a byproduct. Inflation and stalled growth resulted in the stagflation of the 1970s. The Reagan administration targeted inflation by sharply raising interest rates. Increasing unemployment resulted and was made more feasible politically by breaking union power. However, inflation and unemployment put more demands on the state to provide social benefits, including fulfilling the promises (social entitlements) made in previous negotiations with labor, that had exchanged wage moderation for unemployment insurance, social security, and the like. Public debt was the byproduct this time. As that too became untenable, for political and economic reasons, the proposed solution was the deregulation of financial markets. This led to an increase in private debt as financial firms found ever new ways to offer credit. They amplified the money supply for this credit through complicated processes of securitization. However, deregulation accompanied by an ever-riskier use of securitization and derivatives resulted in the financial crisis of 2008 and its accompanying fallout. To prevent another Great Depression, states spent money, once again contributing to a large public deficit."

As social programs grew, governments failed to provide provision to pay for the social programs resulting in elevated levels of public debt in many of the industrialized countries. The failure to increase taxation as a means of covering the shortfall was seen as a concession to the capital class, while increased social programs was done to gain the support of labour. The task in the 1980s in industrialized counties, and more specifically in the US and to a lesser extent in Canada, was to convince workers to accept austerity in the interest of the wellbeing of the whole economy while leaving the holders of capital mainly unaffected and in fact providing them with greater tax breaks while relying on the 'trickle-down' effect. The austerity project took hold and is being used to this day to entrench neo-liberal ideals in society.

\subsubsection{The Evolution of Canada's Neo-liberal Environment}

As the world was experiencing a decrease in productivity and rising inflation, coupled with the oil crisis and economic recessions (which affected Canada in 1982 and 
1990), the rise of Hayekian thought manifested through Thatcherism and Reaganism. The general sentiment in Canada as in other parts of the world turned from the pursuit of full employment towards monetary and fiscal policies supporting balanced state budgets. Battle (1998, p. 324) expressed it as follows: “...the commitment by both the federal and provincial governments to reduce their deficits, ... has dominated Ottawa's agenda since at least the mid-1980s and has been supported by economic and political elites if not most of the electorate." The stepping stone towards neo-liberal policies in Canada was solidified in the result of the election of 1984 . This election produced a majority vote for the Conservative party, known at the time as Progressive Conservatives, headed by Brian Mulroney. This was a drastic change in the Canadian political environment since the Liberal government held power for most of the post-World War II period of Keynesian economic policies (Behiels, 2010).

With a corporate background and fiscally conservative principles in mind, Mulroney tried (unsuccessfully) to reign in the national debt by stimulating market forces through privatization of dozens of crown corporations, the establishment of a free trade treaty with the United States, and cuts to individual and corporate taxes. In 1988, Mulroney was reelected based on his campaign on free trade; however, his popularity was already sliding. Thereafter, he introduced the national Goods and Services Tax (GST), which opinion polls revealed had a very negative reception by the Canadian public. Furthermore, the recession of the 1990s put Canada's financial situation in a very unfavourable position. Mulroney cut corporate taxes, which eroded the tax revenue base but introduced the GST, which seemed controversial and was highly unpopular. His policies, while widely accepted at the present moment, left his political party in shambles 
shortly after his resignation as the Prime Minister. In the 1993 federal election, the Progressive Conservatives secured a mere 2 seats in Parliament, while the Liberals returned to power (Behiels, 2010). When Mulroney left office, he bequeathed to the Liberals one of the largest government deficits in the history of Canada. One might therefore be unwilling to call Mulroney's actions in office as aligned with the neo-liberal agenda since fiscal discipline is one of the primary goals of the Washington Consensus. However, Strain (2007, p. 47) argues that this increase in public debt was not intentional: "When Mulroney assumed power in 1984, not only was the debt large but also interest rates were significantly higher than the rate of economic growth. As a consequence, reducing program expenditures and increasing taxes were not sufficient to halt the explosion in debt." In addition, an environment of low economic growth following a recession n 1981-82 resulted in an inflated deficit despite Mulroney's aim towards neoliberal policy prescriptions.

The next decade saw a step back towards the Liberal government; however, the precedent for neo-liberal reforms had been set. Jean Chrétien as the new Prime Minister promised to revoke the GST and renegotiate the Free Trade Agreement with the U.S.; however, he did not hold his promises and went as far as signing the North American Free Trade Agreement, which extended free trade to Mexico. Another part of his campaign was the national debt, which he promised to bring to 3 percent of the GDP within three years of holding the post of Prime Minister. This promise materialized, but it took massive austerity and cuts to social programs (Behiels, 2010). In Behiels' (2010, p. 119) words, "the floundering Chrétien Liberal government was forced to impose draconian cuts to health, social services, and defense programs, as well as cutbacks to 
transfer payments to the provinces, in order to deal with the ballooning deficit and debt." The 1990s saw a major shift in Canada as described by Murray, Erridge and Rimmer (2012, p. 252):

"In 1993 the central issue of Canada's election was reducing a deficit of 6 per cent GDP and government debt, at that time 70 per cent of national income. Jean Chretien, the Liberal Prime Minister cut state programmes by 10 per cent in cash terms over three years. By 1997-1998 Canada had a budget surplus that was maintained for the next ten years with debt dropping to 30 per cent of GDP."

Despite the resulting elimination of the deficit and the lowering of the national debt, this retrenchment left the equity and equality-creating social policies devastated. Not only were the cuts achieved through the elimination and reduction of funding for state run programs, but 19 percent of public sector employees were eliminated resulting in the loss of 50,000 jobs. The 1990s saw a dissatisfied and demoralized public service in the face of cuts, leading to a diminished quality of federal program and service delivery (Murray, Erridge and Rimmer, 2012; Bourgeois, Hussey, Saulnier, and Wuite, 2012). Bourgeois, Hussey, Saulnier, and Wuite (2012, p. 21) further stipulate about the "unmanageable workloads for many of the employees who were left, and a downloading of services onto Provinces that were unable (or unwilling) to fill the gaps."

The overall results showed a dramatic increase in hospital waiting times, overcrowding in hospitals led to the spread of infectious diseases, funding was eliminated for a significant number of nurses, and even some hospitals were forced to shut down as a result of funding pressures. Public schools experienced the same hardships with the layoff of teachers, the increase of average class sizes from 25 to 35 , and the elimination of special needs classes (Murray, Erridge and Rimmer, 2012). 
Despite reigning in the economic mishaps of Canada, and crippling the social system of the country, it was the sponsorship scandal of money laundering and embezzlement that disrupted the reputation of Chrétien and the whole Liberal party, which played into the Conservatives regaining power in 2006 (Behiels, 2010).

\subsubsection{Harper's Neo-Liberalism}

The Reform Party was founded by Preston Manning in 1987. At the time Manning had hired Stephen Harper as a chief policy officer and over the years Harper's involvement with the party was quite significant. The premise on which the Reform Party was founded is described below.

“Preston Manning's western Canadian populist Reform Party was created by social and fiscal conservatives intent on transforming and reducing the role of the state in the economy as well as in the lives of Canadians. Reform was the product of an ebullient, prosperous New West, especially Alberta, whose expansive economic and political classes were determined to gain greater control over the national political agenda and turn it to their advantage (Behiels, 2010, p. 119)."

In 2000 the party morphed into the Canadian Alliance party in an effort to reunite the right wing with other conservatives. In 2002, Harper was elected to lead the party, who was successful at merging it with the Progressive Conservative party to create the Conservative Party of Canada. In 2006, Harper gained a minority in the federal election based on a platform of lowering the GST and implementing a child care allowance, both of which he achieved once in office. The Conservatives rose to power not solely based on the promises of their campaign but also because of the ongoing conflicts and scandals within the Liberal party, as well as Harper's tactical agreement with the leaders of the NDP and the Bloc Quebecois to dismantle the Liberals as the ruling party. The 2008 
prorogation of Parliament and the ensuing election solidified the power of the Conservatives and delivered more Parliamentary seats for the Conservative government, and the election of 2011 won them a majority vote for a period of five years. The latest election was unprecedented in the fact that the NDP rose to the place of official opposition for the first time in history, while the Liberal party was reduced to third place (Behiels, 2010).

While Harper has not made tremendously radical changes and has been moderate in implementing conservative policies, the general sentiment exists about his "hidden agenda". Tom Flanagan (Behiels, 2010, p. 137) reveals his tactical discussions explaining the reasoning behind this sentiment:

"Harper's electoral victory is a major step toward the ultimate goal: "The work is far from done. Canada is not yet a conservative or Conservative country." $\mathrm{He}$ argues, however, that conservatives must not frighten off the voters by stating or implementing their agenda too suddenly. In politics, one must appear to be moderate, initiate conservative policies incrementally, and, once a position of power is attained, "you control the government, you choose judges, appoint the senior civil service, fund or de-fund advocacy groups, and do many other things that gradually influence the climate of opinion."”

Behiels (2010, p. 124) states that "Harper and his group, [are] all disciples of Friedrich Hayek's ideology of fiscal conservatism.” This premise is evident in his aim for a more efficient and reduced public sector, for a greater emphasis on the market in terms of trade and investments, and for his aim to slash the government deficit within a short timeframe. This ideology aligns Canada's politics with the further Americanization and expansion of neo-liberalism. Behiels (2010, p. 136) elaborates on this point by stating that: 
'Harper's Conservative Party, well grounded in the Reform movement's fusion of "values" conservatism and fiscal conservatism, is a moderate version of the United States Republican Party in terms of its policies, its communication techniques and style, and its approach to funding and campaigning."

According to many political scientists, Harper aims to transform the Conservatives into Canada's “natural governing party”. Behiels (2010, p. 122) further stipulates that this will have a profound effect on the Canadian society:

"Harper's Conservative government will remain in office for a considerable period of time and, in doing so, Harper will transform the federation, and Canada's political culture and political party system, in conservative ways that are not yet fully understood or appreciated."

While the Conservatives hold office, the nature of what represents Canada is arguably moving from the universal health system and social programs towards "a transformed state that promotes a stronger economic union, narrowly targeted social programs, and law and order (Behiels, 2010, p. 122)." The role of the state will be reduced in favour of the market, in line with the Hayekian school of thought.

To summarize Canada's political environment has become more conducive to the neo-liberal agenda. It is recognized that Brian Mulroney's Progressive Conservatives electoral majority in 1984 marked the triumph of neo-liberalism. Throughout the 1990s, under the Liberals and in the 2000s under Harper's Conservatives, the paradigm was not only sustained but significantly widened and deepened.

\subsubsection{Statistical Evidence of the Rise of Neo-Liberalism}

To solidify the argument that Canada has witnessed a rise of disembeddedness of the economy from the socio-political sphere within the context of the current neo-liberal paradigm, some statistical evidence is presented here and then analyzed. 


\subsection{Government Deficit and Debt}

The neo-liberal consensus on fiscal management is the accumulation of budgetary surplus and reduction of government debt. The surplus/deficit graph below suggests that with the onset of the neo-liberal paradigm in Canada, which could be marked by the rise of Mulroney's Conservatives to power in 1984, the deficit increased significantly to $\$ 37.2$ billion or 8.1 percent of the GDP in $1984-85$, but then slowly began to climb towards a surplus position keeping in line with the paradigm. In the years following the economic crisis, the government ran a deficit as a result of financial support to financial institutions and stimulus efforts, but it is now trying to return to the 'balanced-books' position with the use of austerity measures in line with neo-liberal objectives, thus contributing to the disembeddedness of the economy in Canada.

Table 1 Federal Budgetary Surplus of Deficit, 1966-67 to 2012-13 (percentage of GDP)

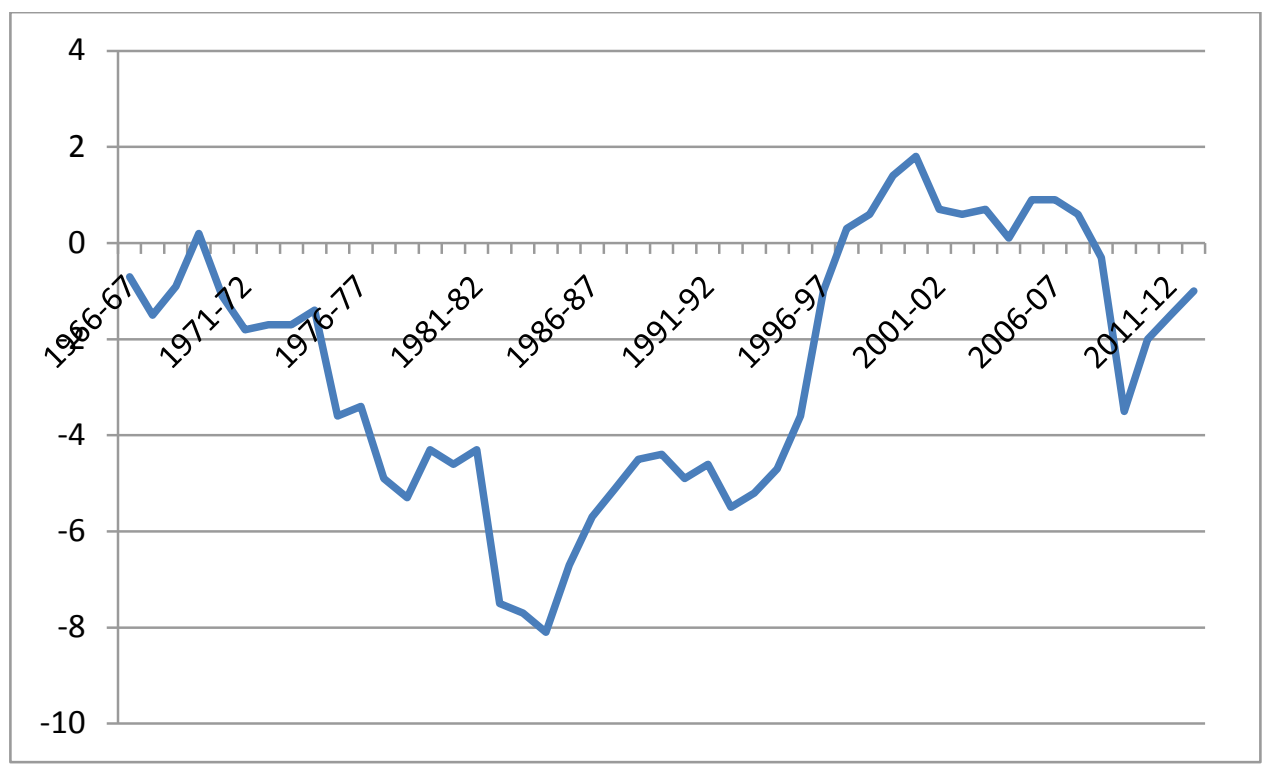

(Department of Finance, Fiscal Reference Tables, 2013) 
A similar situation is witnessed for public debt. The historical trend shows an exponential increase in government debt after the end of World War II and as Canada began to move towards the principles of the welfare state under which embeddedness was experienced. In more recent years, federal debt began to decrease, sliding from a peak of 67.1 percent in 1995-96 to 33.1 percent in 2012-13 (Department of Finance, Fiscal Reference Tables, 2013). This serves as indication that neo-liberal objectives take precedence for governmental policy. If the elimination of debt and deficit is at the forefront of the governmental agenda, social services provision is likely suffering from the deferral of funding and cuts to spending attributed to austerity. This is a strong indication of the growing disembeddedness in Canada.

Table 2 Federal government, total direct and indirect debt, less sinking funds, by type, 1867 to 1975 (millions of dollars)

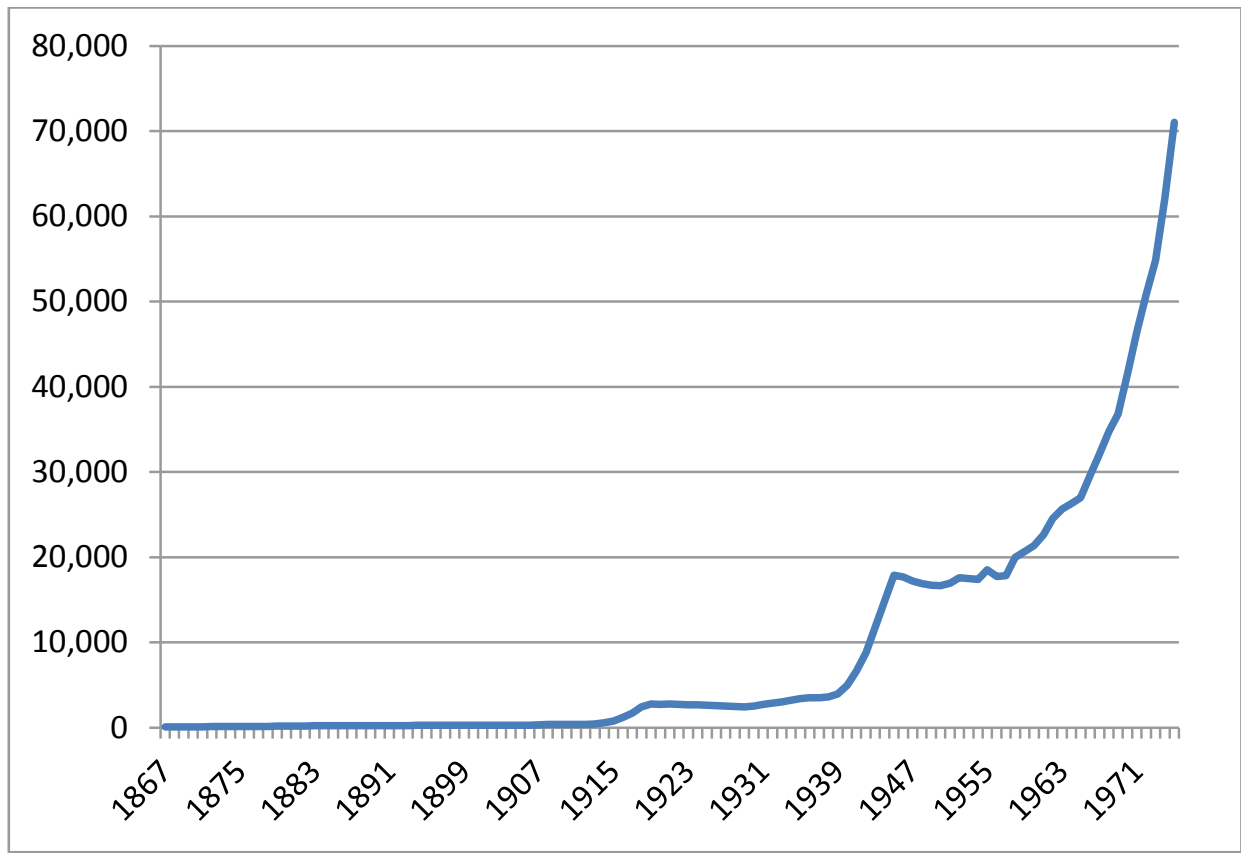

(Leacy, Urquhart and Buckley, 1983) 
Table 3 Federal Government Accumulated Deficit (i.e. Federal Debt),

1966-67 to 2012-13 (percentage of GDP)

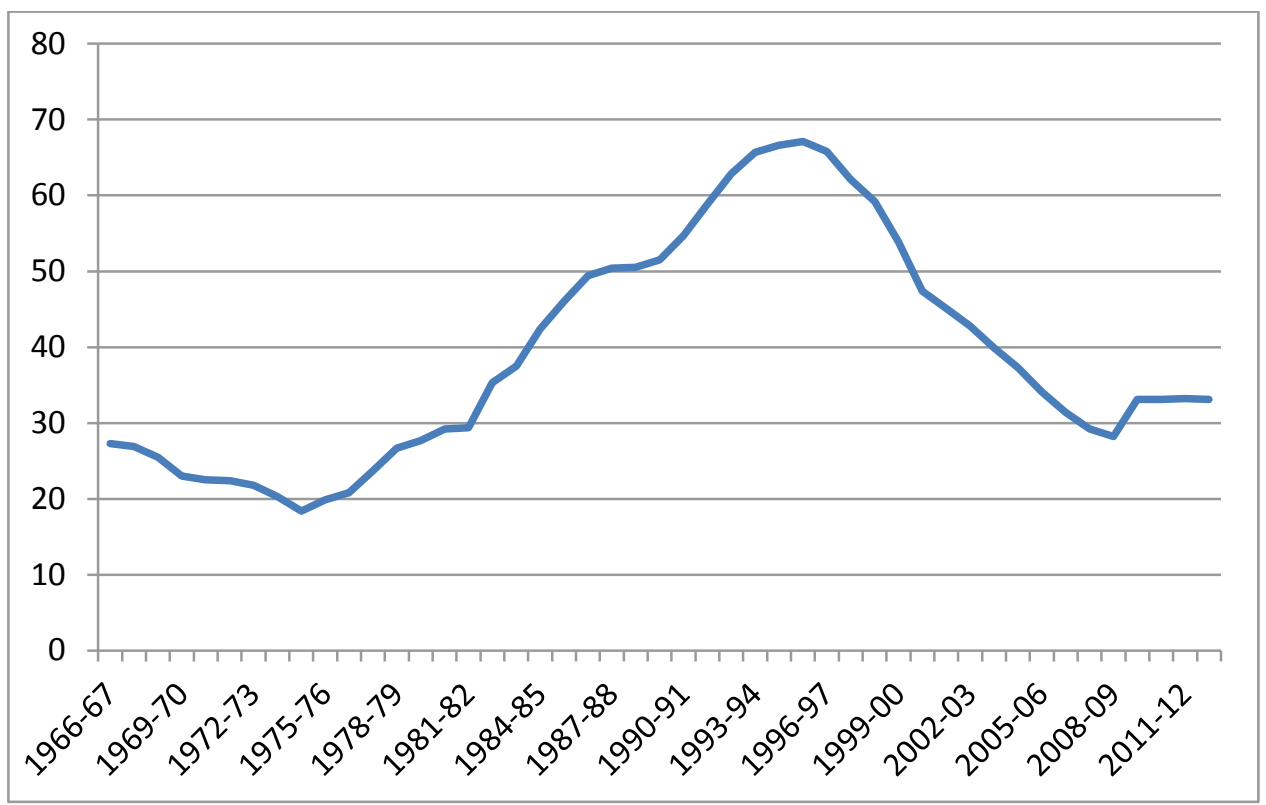

(Department of Finance, Fiscal Reference Tables, 2013)

\subsection{Government Expenditures and Revenues and Government Social}

\section{Expenditures}

The previous charts show a historical trend of substantial growth in government debt after the end of World War II. This is representative of new expenditures of the federal government particularly related to the move towards welfare state provisioning. The historical trend below also demonstrates increases in both expenditures and revenues, indicating a move towards economic embeddedness in Canada. 
Table 4 Federal government budgetary revenues and expenditures, 1867 to 1975 (millions of dollars)

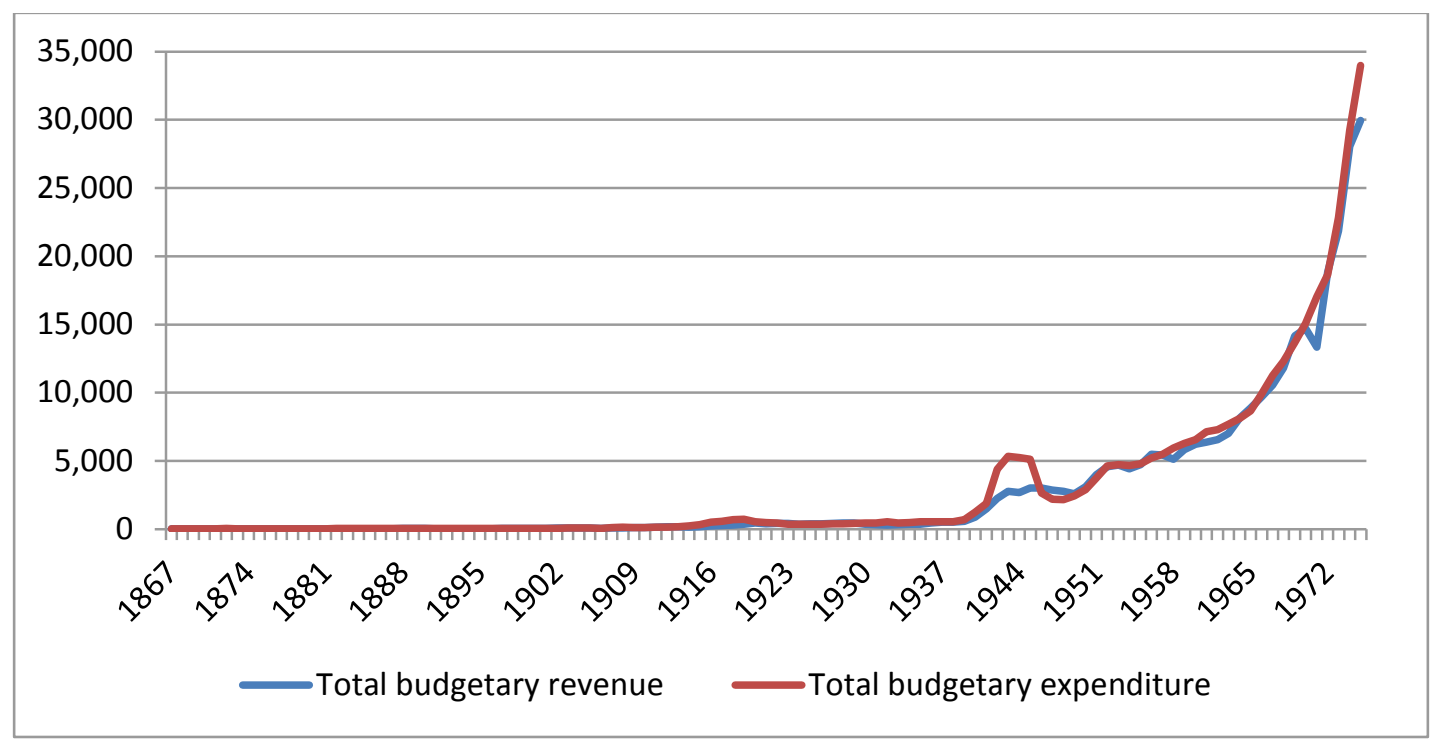

(Leacy, Urquhart and Buckley, 1983)

In absolute terms, expenditures started to increase with minor dips at times of recessions (Table 4). However, if expenditures are examined as a percentage of GDP (Table 6), one can see a progressive decline starting in 1982-83, with the onset of neoliberalism in Canada and with the start of disembeddedness. Another key observation made from the tables below is the fact that for a number of years expenditures consistently exceeded revenues. Within a neo-liberal mode of thinking, increases in expenditures are not matched with increases in taxation. In fact, taxation is reduced and justified using the 'trickle-down' effect. Austerity measures are then systematically engaged in order to bring down expenditures. 
Table 5 Federal government budgetary revenue and expenditure, 1966-67 to 2012-13 (millions of dollars)

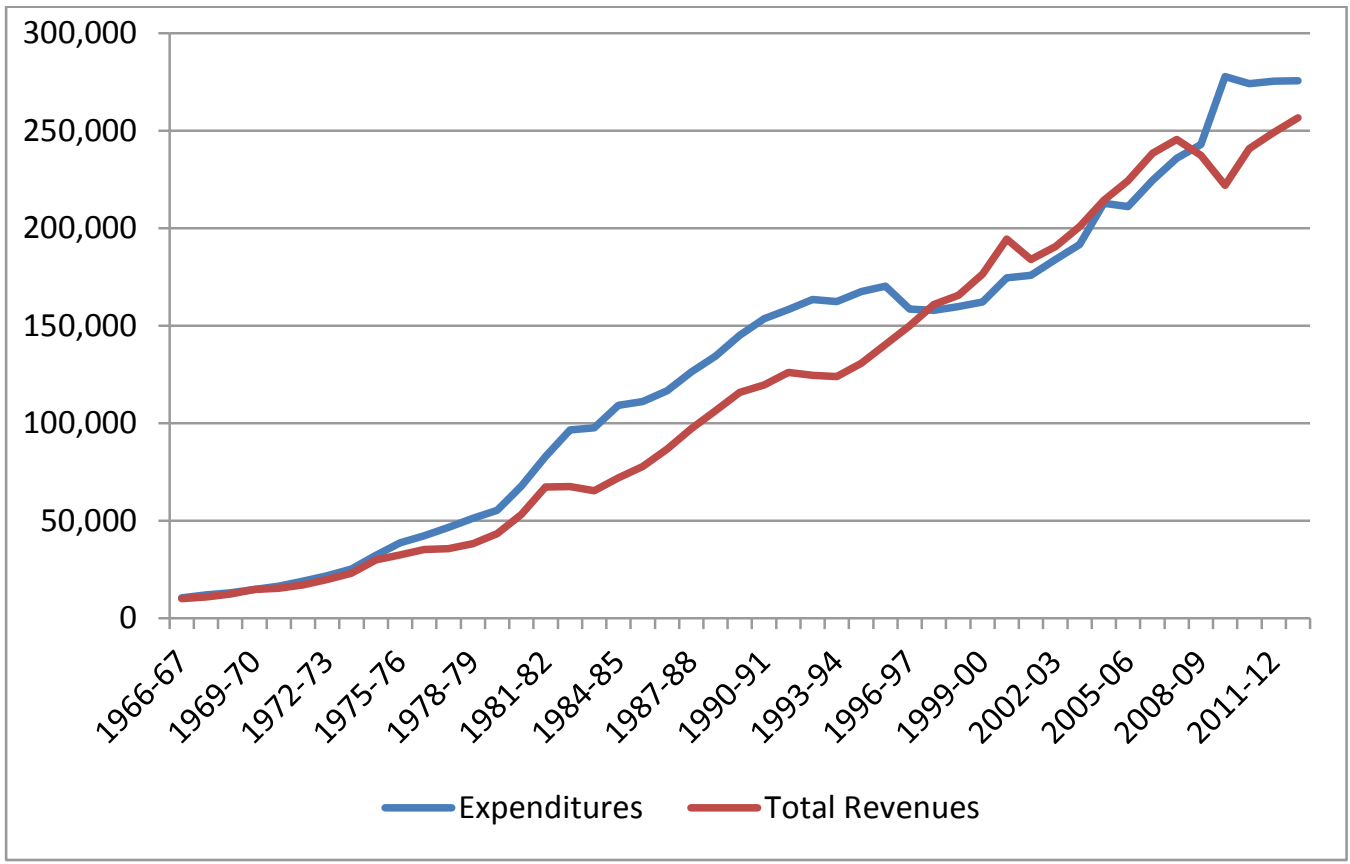

(Department of Finance, Fiscal Reference Tables, 2013)

Table 6 Federal government budgetary revenue and expenditure, 1966-67 to 2012-13 (percent of

\section{GDP)}

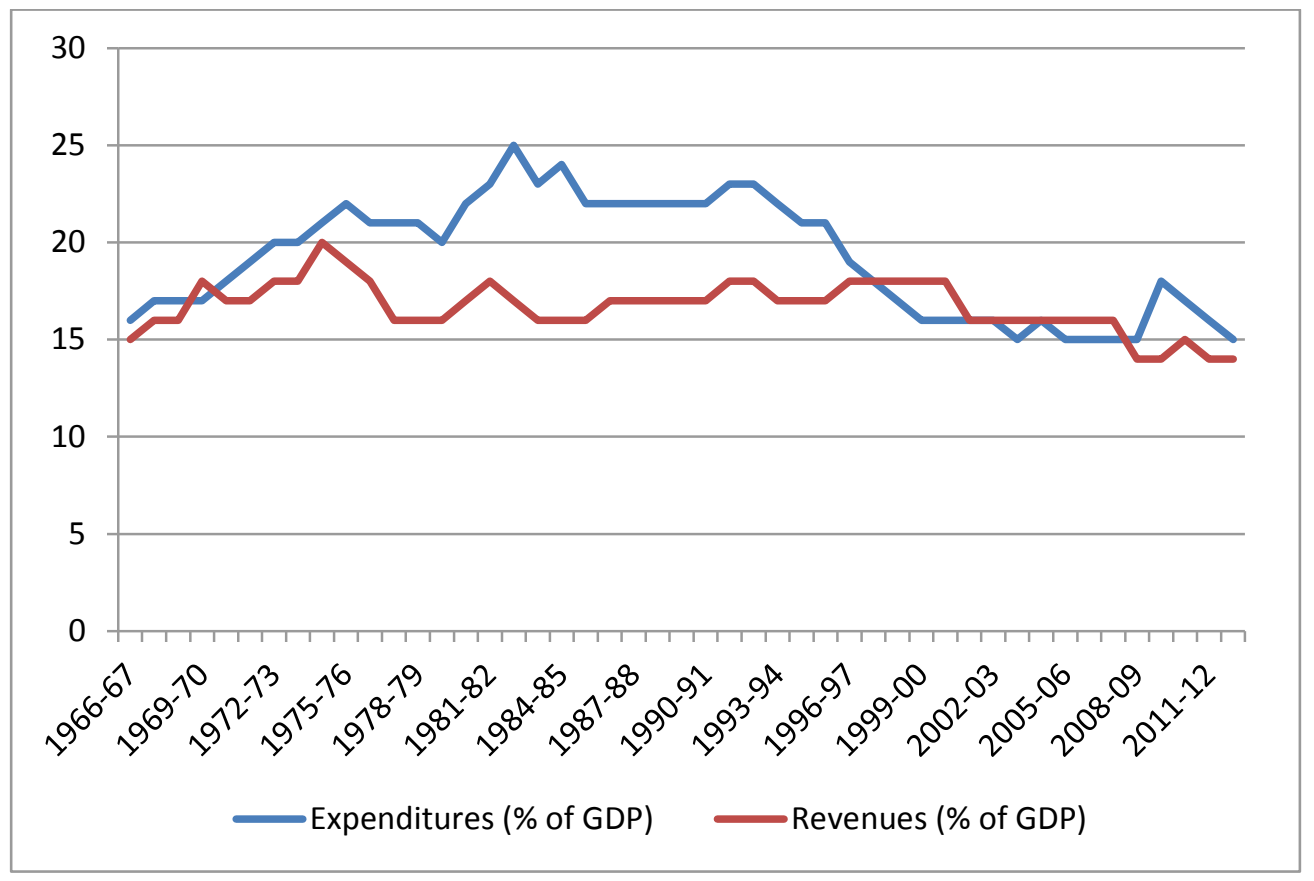

(Department of Finance, Fiscal Reference Tables, 2013) 


\subsection{Government Employment}

Government employment expenditures in Canada are on a declining trend in reference to GDP. Since the neo-liberal state favours a leaner public sector, government employment, which was once a source of economic stability, is effected in a negative way, contributing to the growing disembeddedness.

Table 7 Compensation of employees paid by government, 1981 to 2012 (percentage of GDP)

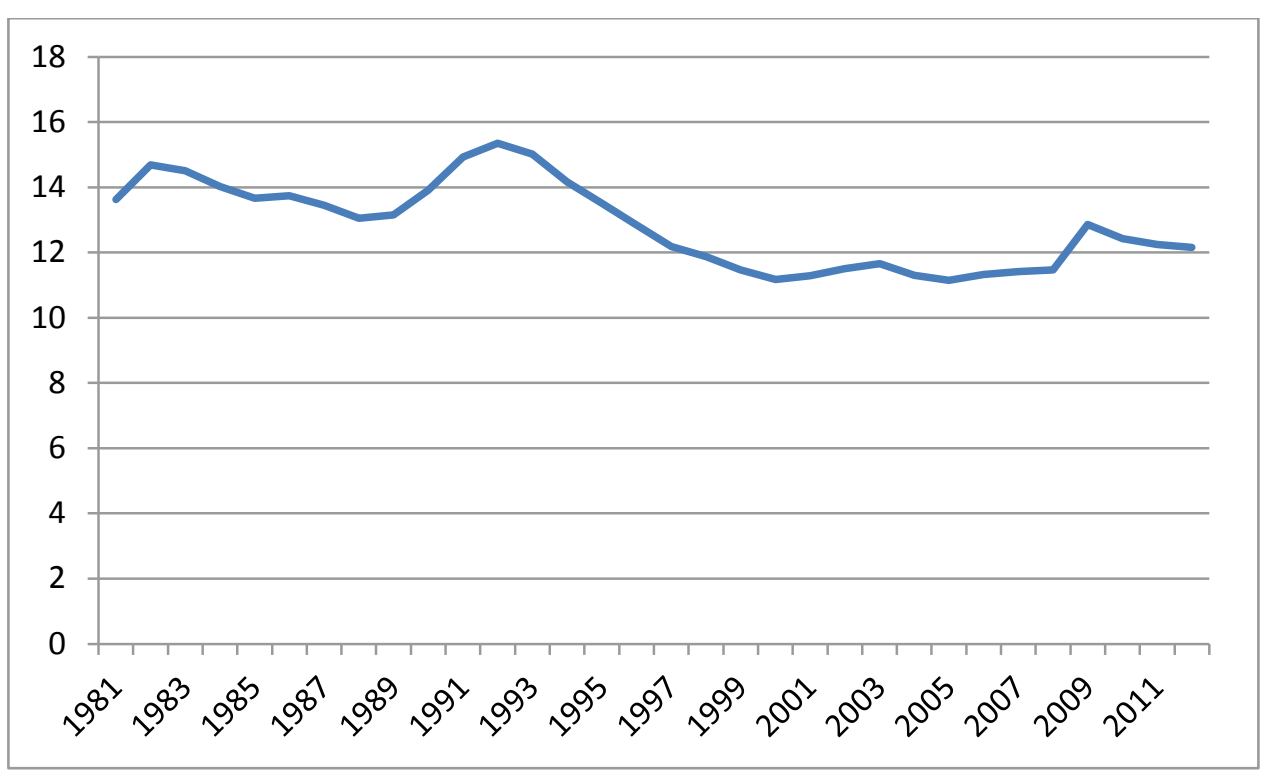

(OECD Statistics, 2014)

\subsubsection{The Global Economic Crisis of 2008}

The global financial crisis did not happen overnight. It took many significant events and forces coming together to fuel the unsustainable bubble that eventually caused millions around the world to lose their savings, jobs, and homes. A dramatic change in policy and in the regulatory environment caused new developments in the financial sector, ultimately bringing the international system to the worst crash experienced since the Great Depression. The neo-liberal regime of minimal intervention contributed to 
significant deregulation of the financial sector. As a result, the financial sector, especially the one based in the United States, began to grow at unprecedented rates, no longer having strong and stable ties to the real economy of production and output. In other words, the financial sector became an independent entity, the assets of which could easily outgrow a country's GDP.

Deregulation of the financial markets began around the world and the pressure to create a more desirable environment for capital flows caused a "race to the bottom". The pressure emanated from the deregulation of the US financial sector which started under US President Bill Clinton and continued under President George Bush Junior. The competition among nations has increased for shares of the growing international financial market, and waves of global 'hot money' seeking the highest returns began to undermine exchange rate stability (Crotty and Epstein, 1996). In this environment, the financial sector was able to get a tighter grip on policy and regulation in countries around the world. In the United States in particular, the years of the Clinton and the Bush administrations saw unprecedented deregulation, along with Bush's tax cuts, creating an unsustainable period of hype and boom. Continuous lobbying and pressure from the financial sector paid off in 1999, when one of the most pivotal deregulatory actions took place - the repeal of Glass-Steagall Act. This Act had long separated commercial banks (which lend money and are more conservative in nature) and investment banks (which organize the sale of bonds and equities and are more risk prone). With the dismantling of this separation, banking practices took on more characteristics of investment banks, with high leveraging and big risk taking, contributing to instability and high levels of speculation (Stiglitz, 2009). 
The innovation of the financial sector has brought into existence the expansion of the market for derivatives, financial instruments which are not backed by real assets as is the case with equities or mortgage and bond debts. . Derivatives rely on underlying assets, indexes, or interest rates to determine their value. Packaged mortgages are an example of such derivatives. Futures, options, swaps, etc. are the kind of financial contracts classified under the derivative market. These financial instruments are complex (Wolf, 2007) and have even been referred to by George Soros as "financial weapons of mass destruction" (Stiglitz, 2009). According to Mayer-Foulkes (2009), the derivatives market grew from $\$ 72$ to $\$ 683$ trillion between 1998 and June 2008. In comparison to world GDP of $\$ 50$ trillion, derivatives are made up of astounding amounts of investments, with the potential to destabilize the world economy. Because derivatives rely on packages of underlying assets, it is often hard to assess the risks involved in the purchase of these financial products. Hedge funds have also contributed to the undermining of the system. As mostly private funds, not available to the general public, they function on the premise of high return generation through the use of leveraged and derivative practices. In recent years, they have become new financial players in charge of significant amount of funds, and having the power of distorting the whole financial system (Wolf, 2007). Securitization and hedging, serving as mechanisms to offset potential losses, lie at the core of the derivative markets. These practices converted loans and other financial products into complex, potentially toxic and destructive financial instruments, based on the increasing and risky leverage they offered to financial institutions (Roubini, 2009). 
The tax cuts that were passed during the Bush administration relieved the upper echelon of society of much of its tax burden. The availability of money in the upper class made them look for ways of investing this extra currency in a way that would provide a higher return. The flood of liquidity made money readily available in mortgage markets, even to those who wouldn't normally be able to borrow, creating unsustainable lending practices that involved a high risk factor (Stiglitz, 2009). The decline in the underwriting standards for mortgages produced an environment where it was no longer necessary to prove your financial stability and the ability to pay the debt off (Taibbi, 2009). So called sub-prime mortgages, lent to individuals with high risk of non-repayment, thus became a norm for the financial sector. Furthermore, the interest on mortgage and corporate debt in the US is tax-deductible, encouraging businesses and individuals to leverage themselves out by taking on massive debt burdens (Stiglitz, 2009). Mortgages were then converted to derivative market products that provided the underwriting lending banks with the securitization of their loans. In other words, they sold the mortgages; their returns were based on the underwriting fees. The packages of mortgages are what generated high returns to the purchasing constituents. At that point, the banks were no longer in the position to fret about debt repayment, and were therefore encouraged to lend even more. As such, often thousands of mortgages were packaged and sold en masse to unsuspecting banks, insurance companies and pension funds around the world (Taibbi, 2009). Once it became evident that a part of a package contained defaulted mortgages and unsustainable lending products, panic spread through the sector causing a collapse of the system (Taibbi, 2009). On the international markets, large surpluses were invested in US assets in a way that blew up the property market bubble. Once a collapse in the sub- 
prime mortgage market was detected, it spread to markets around the globe because they were all invested in it through the derivatives they bought.

Ultimately, most individual mistakes come down to one, which is the belief that markets are self-adjusting and that the role of government in regulating them should be minimal (Stiglitz, 2009). According to Panitch and Gindin (2009, p. 27), "Government is necessary to make business act responsibly. Without it, capitalism becomes anarchy. In the case of the financial industry government failed to do its job..."

\subsubsection{Conclusion}

This chapter has provided the proper background in examining the evolution of the social order from the emergence of the welfare state in a post-depression, post-war era to the rise of new value principles of neo-liberalism both in general terms and as it applies to Canada more specifically. The background provided a context for the most recent turn of events in global capitalism - the global economic crisis of 2008. Its manifestation abroad and in Canada propels us into an era of austerity measures and the societal response to these measures being enforced by a more increasingly neo-liberalist state. This thesis will explore the concepts of austerity and societal response in Canada through the application of Polanyi's Double Movement of embeddedness and disembeddedness of the economic sphere from that of society. The following chapter goes into depth on the theoretical front, exploring Polanyi's concepts and adapting them to understand the contemporary period. 


\section{Chapter: Karl Polanyi's Theory of the Double Movement}

\subsection{Polanyi’s Theoretical Perspective}

Karl Polanyi was born in Vienna, in the former Austro-Hungarian Empire, but exiled to London during the 1930s with the rise of fascism in his home land. He later moved to the United States where he wrote the work by which he is most remembered -

The Great Transformation, which was published in 1944. Polanyi's work was shaped by his living through a period of "unparalleled human disasters - two world wars, the Great Depression, Fascism, Stalinism... (Hann and Hart, 2009, p. 4).” Just as Hayek is considered one of the key theorists behind neo-liberalism, Polanyi is considered as one of the most important theorists behind the critique of unrestrained market forces, and thus of the neoliberal creed of the contemporary world.

The Great Transformation describes the transformation from pre-capitalist societies into the modern market based society. As an economic historian, Polanyi used large spans of time to evaluate the progression of market societies through the history of capitalism. Polanyi makes his claims through two distinct perspectives, the first being through a historical argument and the second through an anthropological argument (Inayatullah and Blaney, 1999). The historical perspective examines the birthplace of industrialization, England, between the late eighteenth and the end of the nineteenth centuries. He draws attention to the Speenhamland Act of 1795 which "guaranteed support for the poor according to a scale depending on the price of bread (Baum, 1996, p. 8)." This arrangement upheld the "right to live" by a collective provision for those less fortunate. In 1834 however, the Poor Law Reform Act was passed, abolishing the 
previous arrangements of provision for the poor. Polanyi cites the consequences as being devastating. As a result of this injustice, starting in the late 1840 s, society began to rebel and try to protect the wellbeing of the people against the free market apparatus. Parliament then started introducing a multitude of laws that served to protect both society and nature from the harmful effects of the market system (Block and Somers, 1984).

The anthropological perspective approaches the role of the economy in precapitalist societies by showing the embeddedness of economic activities in social relations. By dwelling on simple tribal societies, Polanyi makes an inference about human nature, claiming that the self-regulating market has never been a natural occurrence. By specifying key concepts which are embodied by embeddedness reciprocity, redistribution, and householding - Polanyi shows the introduction of the concept of the self-regulating market as a foreign idea to society (Sandbrook, 2011).

The Great Transformation embodies such ideas as commodification, embeddedness, reciprocity and redistribution, economic fallacy and stark utopia, the Double Movement, and democracy and freedom. Throughout the years, many theorists have used the Great Transformation and its concepts in exploring new political, economic, and social frontiers. In what follows, these concepts will be explained in greater detail to demonstrate the unique nature of Polanyi's thought and his contribution to understanding the development of capitalism. Further, an appreciation of his work from a reading of those authors who have explained or developed his ideas will be put forth. The two sections will be bound by the discussion taking place in this thesis. Lastly, this chapter will focus on the importance of Polanyi's theories through their 
application to modern neo-liberalism in the context of contemporary post economic crisis scenario.

\subsubsection{Key Concepts in Polanyi}

\subsubsection{Commodification}

The great transformation happens with the move of pre-capitalist modes of society to the modern and industrial market system or market society. One of the key aspects of this transformation is commodification of certain aspects of human life, more specifically land, labour, and money. What is meant by commodification is the change in the nature of these aspects of life from self-actualizing agencies into tradable market goods. Polanyi referred to land, labour and money fictitious commodities, since they were not produced on the market but are utilized in trade. Block (2008, p. 3) summarizes that "Since the market acting alone cannot produce these things in correct and sustainable quantities, the state must manage the supply and demand for these critical inputs to the production process."

By means of commodification, nature and human beings' fates came to be determined by market forces with a constant expectation of gain or profit. Polanyi (2001, 71) summarizes fictitious commodification as a function "to subordinate the substance of society itself to the laws of the market". Ankarloo (2002, p. 5) further expands on this point, stating that:

"This commodification makes human social life dependent upon the fluctuations of the market, to the supply and demand of the market and hence threatens to annihilate human beings as such." 
In the words of Sandbrook (2011, p. 420): "To expose these essences to the mercenary calculations of opportunistic 'rational' actors leads to the 'demolition' of society and nature." He (2011) further reiterates that laissez-faire economics makes unsustainable demands on ordinary people; people's abilities are stretched thin to accommodate the market structure.

Commodification leads to the disembeddedness of the economy from social relations. This causes cultural alienation, isolation, depression among people who are treated as mere commodities and whose work is debased from social relations (Baum, 1996).

Within the neo-liberal paradigm in Canada, while land, labour and money is already commodified, recent years have witnessed further commodification of aspects of life. A few examples of this commodification is the privatization of 23 crown corporations under Brian Mulroney's regime and the degradation of labour's bargaining power witnessed through declining unionization of workers. The Quebec Student Movement fought against the commodification of education and the subjugation of this intrinsic right to knowledge to the power of market mechanisms.

\subsubsection{Embeddedness}

Polanyi positions economic structures into those that are embedded and those that are disembedded from social relations. In an embedded economic structure, economic activity is integrally connected to social relations in the form of familial, kinship, religious or political obligations and regulations (Sandbrook, 2011). 
To elaborate on the concept of embeddedness, Polanyi explores the individual notions of reciprocity, redistribution, and householding, which allow the economic sphere to be enmeshed into social relations (Sandbrook, 2011). Polanyi makes a claim that in societies functioning before the emergence of capitalism, those principles were the major ways by which societies were organized. These were the "main forms of integration and resource allocation (Ankarloo, 2002, p. 2)." In such an organization of society, there was no need for the market system to play the central role in the organization of life as is seen in modern society. The market was simply part of social life and it was subjugated to people's utility, while being governed through social relations of status, kinship, hierarchy, etc. Even poverty was not a problem in itself, as long as those less fortunate were "integrated in a community with survival skills and a strong sense of solidarity (Baum, 1996, p. 43).”

In an age of industrial and much more complex society, it is the socio-political forces that are able to hold the economic forces in an embedded position through institutional regulation (Beckert, 2009). Thus, social and political action and engagement would need to exert authority over economy in order to be considered embedded by Polanyi's standards.

"The term "embeddedness" is not only an analytical term but also alludes to the political or social reformist task of stabilizing a (democratic) organization of society through the institutional regulation of markets, especially in the realms that Polanyi termed fictitious commodities: land, labour, money (Beckert, 2009, p. 41)."

Munck (2010) portrays the era of Keynesian economics and the controls provided by the Bretton Wood system as an embedded form of socio-economic life. He cites 
Ruggie for coining the term "embedded liberalism" to describe this era, in which market allocation of resources took place but was constrained by the political process which catered to social needs.

Disembeddedness on the other hand, is experienced with a greater degree of separation of the economic and the socio-political spheres, with the latter having limited or no control over the former. Allowing the self-regulation of the economy ultimately releases it from socio-political influence and allows for the commodification of vital parts of life as well as for an economic fallacy, which will be discussed below (Baum, 1996). In the age of neo-liberalism, where corporate interests prevail over those of society, disembeddedness is systematically being implemented through evolving state legislation. In an effort to produce economic growth, corporate taxes are reduced, public expenditures are halted, impacting those relying on social provisions.

In the spirit of Polanyi's thought, Baum (1996) argues that the state itself may also become disembedded from society. "This happens when the state, without respecting communities and listening to citizens, imposes its own governing logic from above to the detriment of the social fabric and the vitality of society (Baum, 1996, p. 45)." As will be discussed in greater detail below, in undertaking austerity measures, the government of Canada refused to provide key information regarding the cuts to society in general. This lack of transparency points to the undemocratic nature of state actions and is a clear indication of the continuation of disembeddedness of the state from society. 


\subsubsection{Economic Fallacy and Stark Utopia}

While classic liberals saw the market economy as a natural occurrence, stemming from the guidance of the invisible hand (Ankarloo, 2002), Polanyi (2001) claimed that commodification and disembeddedness caused by the market economy was unnatural to society, antisocial, and in fact morally wrong (i.e. economic fallacy). Relying on a selfregulating market was seen by Polanyi not only as utopian and impossible, but ultimately self-destructive (stark utopia) (Herman, 2012). "There was nothing natural about laissez-faire; free markets could never have come into being merely by allowing things to take their course (Polanyi, 2001, p. 139)." The liberal state, subjugated to the principles of wealth building through the function of a purely fundamental market system pressed on with the implementation of the market economy. Polanyi (2001, p. 141) strongly believed that a "laissez-faire economy was the product of deliberate State action. . . Laissez faire was planned", it was not by any means a natural and spontaneous occurrence. Free markets were the outcome of an expansion of state intervention and reforms. Government administration had to be "constantly on the watch to ensure free working of the system (Polanyi, 2001, p. 147)." "The road to the free market was opened and kept open by an enormous increase in continuous, centrally organized and controlled interventionism (Polanyi, 2001, p. 146)." In other words, "the expansion of market relations is a planned process backed by the coercive powers of the State and the economic might of corporate elites (Palacios, 2001, p. 4)." Parallels can be drawn to current neo-liberal political regime. For example, many countries around the world experienced change in state policies as a result of imposed regulations through the World Bank and the IMF. The neo-liberal regime did not spread organically by being the 
optimal way of organizing society, rather it was imposed by the coercive power of the state (in this case the hegemonic American state) and the economic might of corporate elites.

Polanyi was not opposed to markets or the market system, he simply objected to market fundamentalism and the idea of the self-regulating economy, and was extremely cautious about the increased disembeddedness of economic forces from socio-political influence (Hann and Hart, 2009). Block and Somers (1984) describe the Polanyian state as acting in the interests of the general population, transcending conflicting and particular interests. The state does not belong to either the society or the market; it acts in the general interest of dominant forces either inclined towards the betterment of society or the propagation of the market system. "The state is pulled in contradictory directions by the imperatives of private accumulation and the imperatives of democratic legitimation (Block and Somers, 1984, p. 68).”

\subsubsection{Double Movement}

Polanyi viewed as morally wrong the creation of fictitious commodities within the market economy. Moreover, the commodification of land, labour and money, and market disembeddedness also had a limiting factor. That limiting factor is characterized in Polanyi's notion of the Double Movement or counter-movement. As deregulation of the market and the disembedding of society from economy takes place, a simultaneous movement is seen from society in order to self-preserve and protect (Baum, 1996)."

Polanyi's (2001, p. 132) description of the Double Movement goes as follows: 
"Let us return to what we have called the double movement. It can be personified as the action of two organizing principles in society, each of them setting itself specific institutional aims, having the support of definite social forces and using its own distinctive methods. The one was the principle of economic liberalism, aiming at the establishment of a self-regulating market, relying on the support of the trading classes, and using largely laissez-faire and free trade as its methods; the other was the principle of social protection aiming at the conservation of man and nature as well as productive organization, relying on the varying support of those most immediately affected by the deleterious action of the market primarily, but not exclusively, the working and the landed classes - and using protective legislation, restrictive associations, and other instruments of intervention as its methods."

"Inevitably, society took measures to protect itself, but whatever measures it took impaired the self-regulating market, disorganized industrial life, and thus endangered society in yet another way (Polanyi, 2001, p. 3)."

While the market society is artificially crafted by state agents in order to subjugate nature, people and money to the whims of the market, society rises in a spontaneous and natural way. Valderrama (2012, p. 100) describes the countermovement as spontaneous in nature as "It is not the product of a conspiracy between leftleaning intellectuals and trade union leaders, but is instead a natural reaction of selfprotection".

This counter-movement serves to "moderate the excess of market fundamentalism (Dale, 2010, p. 369)" and limit the harmful and destructive effects imposed by the market. In other words, the Double Movement is society’s “inevitable self-protection against the commodification of life (Herman, 2012, p. 626)." Not only is the Double Movement inevitable, it is also necessary for "the successful and stable institutionalization of the role of the market in social life (Inayatullah and Blaney, 1999, p. 329)." Bringing economic forces under democratic socio-political regulation is the ultimate goal of this phenomenon. 
Manifestations of the Double Movement are seen through the emergence of civil society, social protests, strikes, and other expressions of discontent with the order of events. Non-governmental organizations, the elderly, students, public sector workers, and unions are often at the forefront of physical manifestations; however, many other facets of "civil society" partake in political processes that then sway regulation in favour of society (Dale, 2012). It is important to mention that society and state action is the main agency in the concept of the Double Movement. However, little seems to be extended to intermediary agencies such as classes, interest groups, families, individuals, etc. Since society is so fragmented, it is important not to over-generalize what constitutes society and what wants they represent. For example, not everyone in the general society agreed with the Occupy Movement and the Quebec Student Movement. In fact, many people opposed the uprisings and supported the status quo.

While the 1960s-70s saw the emergence of many social movements, such as, the civil rights movement, the feminist movement, and the peace movement, that had lasting impacts, Baum (1996) argues that the most recent years have seen less and less action. Cultural pessimism and social passivity is the culprit in his interpretation. On the other hand, anti-globalization movements have been popping up on a regular basis throughout both the industrial and developing nations, demonstrating that society is not standing idly by as neo-liberal regimes give more and more power to the unfettered market (Colatrella, 2011).

While society is the primary agency by which Polanyi foresees the extension of the counter-movement, through democratic forces, society has an influence over state 
actions in passing of legislation. In the form of resistance, state action aims to limit the continuous commodification of land, labour and money through taxes and tariffs, laws and regulations, and social safety nets. Beckert (2009, p. 51) refers to the Double Movement as a "result of political intervention in markets in the light of their social consequences." Kim (2010, p. 373) claims that:

"Civil society inevitably reacts against unfettered market forces to avoid marketrelated social risks, and to preserve necessary social fabric and norms. As a result, the state - especially in capitalist democracies - is under great pressure to provide adequate social welfare to those who are increasingly exposed to market-related social risks, and a seemingly nice equilibrium of social compensation against neoliberalism ensues."

The Double Movement manifested mainly on the local and national plane under Polanyi's observation. This is the case to this day because political action and sovereignty are mainly concentrated at that level. Sandbrook (2011, p. 424) states that "national and local levels, despite globalisation, are arguably still the most inclusive levels at which solidarity can realistically be mobilised." However, scholars (Sandbrook, 2011) state that the perspective must be expanded to a global plane in order to successfully address the problems of globalization in modern day. The Quebec Student Movement was successful because it concentrated the opposition of people from many backgrounds but all in a single province in Canada, whereas the Occupy movement was a global movement with national strains focused on change in state regulations.

\subsubsection{Democracy and Freedom}

According to Dale (2010, p. 369), Polanyi was "positioned within the socialdemocratic mainstream for which the only realistic desirable goal is a regulated form of 
capitalism." The counter-movement shows that sociopolitical elements will act in a way that assert or imposes greater democratic control over the decision making apparatus. Polanyi saw a market economy under democratic control as being inherently embedded in society as it is the citizens as opposed to market mechanisms that have the ultimate say in the functioning of the economy (Herman, 2012). In a socio-democratic, embedded economy, "markets are merely the means for achieving the goals set by democratic politics; they exist, but they do not determine the constitution of society (Valderrama, 2012, p. 89)."

Embedded markets that would connect the economy to the "moral fabric of society", through institutional means, were the ultimate goal for Polanyi (Beckert, 2009). He envisioned society not totally without the commodification of land, labour, and money, especially not wanting to fall into the trap of romanticizing pre-capitalist societies. However, he believed that society is able to embed the commodification of these functions. For example, wages could be arranged through a democratic decisionmaking process, which would ensure that wages are not set as the result of the market (Valderrama, 2012).

In his conception Polanyi regarded freedom as a social matter which carried with it the responsibility for one's choices about society. The virtues of sympathy, shared values, commitment and cooperation rooted in morals and ethics of a society led to the realization of responsible individuals who were committed to the well-being of their community as a whole. "Constant preoccupation with material gain stimulated unnatural, unethical, and immoral practices, and represented a threat to the achievement of freedom 
(Filip, 2012, p. 77)." To Polanyi, poverty and inequality prevented the freedom of individuals by hindering their options in life. Basic human needs, such as health, and education had to be provided for in order to ensure freedom. This is radically different from a neo-liberal Hayekian perspective that sees individualistic attainment as ultimate freedom (Filip, 2012). Kari Polanyi-Levitt (2012, p. 14) states that "within each of us is the need for the protection of a social support system that accords us self-respect and dignity, and thus personal freedom.” By Polanyi’s standards, freedom was achieved through a socio-democratic redistribution of wealth, stating that "the question of distribution ... was a question of social justice and could not be solved in the marketplace (Filip, 2012, p. 69).”

According to Baum (1996, p. 12), Polanyi believed that the self-regulating market is non-compatible with democracy. "Either the free market will give way to a more cooperative, social economy, or, if the free market economy remains in force, it will increasingly depend on authoritarian or even fascist protective rule." The current government led by Harper is viewed by many as more authoritarian than any preceding ruling parties in Canada. More and more state actions are undertaken unilaterally without broad consultations.

\subsection{The Use of Polanyi's Thought by Other Theorists}

How have Polanyi's theories and specifically the concept of the Double Movement been used in crisis and post-crisis situations, historically, across the globe? A range of literature on the use of Polanyi's thought will be evaluated here in order to learn what others have exposed through their research. Drawing on these secondary analyses 
and applications of Polanyi's theory will give additional support to the praxis of this thesis.

Dale (2012) brings forth the idea of the pendulum swing between society and the market. He brings to our attention the particular reason for which the pendulum has swung extremely in favour of the market in the last 30 years - financialization.

Deregulation of finance has created an order in which corporate actors gain greatly, even in times of crisis and post-crisis. Dale points out that banks that were heavily involved in the creation of the crisis and those receiving government bailout packages were already increasing their executive salaries and bonuses in 2010, merely two years after the financial collapse. As the state recedes from functions of societal support and undertakes the role of a regulatory enforcer of the rules of the market, protests from certain members of society, such as students and unions become more prevalent. Furthermore, Dale does not see the pendulum swinging towards social care. He sees "the double movement is at best stalled, at worst blocked (Dale, 2012, p. 18)." While neo-liberal capitalism is undergoing an ongoing legitimacy crisis, he believes that neo-liberalism will be sustained by the underlying macroeconomic and macro-institutional conditions around the globe.

Dan Herman's (2012) central argument in his work "The Missing Movement: a Polanyian Analysis of Pre-Crisis America", is similar to Dale's. Herman elaborates on how labour was blamed for the stagnation and limited growth reached in the 1960s, and its consequent retrenchment in the face of growth and profit. Labour conditions began deteriorating, leading to the concentration of wealth in the top echelons of society and increasing inequality. Furthermore, we saw a stagnation of real wages and growing unemployment rates. Despite a visible trend towards the disembedding of the economy, a 
counter-movement did not materialize on the scale Polanyi predicted. The failure of the counter-movement to provide the counterweight to market favouritism is a result of financialization, and more particularly access to credit and the accessibility to the stock exchange as a means of investment. Herman's (2012, p. 625) main argument is summarized as such:

"Polanyi's concept of a societal counter-movement was absent due to explicit strategies enacted by financial elites to circumvent the mitigating role a double movement would play in lessening the harmful effects of American capitalism. In particular, the double movement that should have sought to lessen income inequality, unemployment and wage stagnation was instead replaced by access to cheap credit and the democratization of market investments that spurred consumer purchasing power and a false belief that was good for the markets was good for working class Americans."

Debt and credit began to be perceived as real wealth, and people subsequently went along with the story of the American Dream and chose to support financial markets and the processes sustaining them. According to Herman, the mass debt and investment culture not only disembedded social relations from the economy, it also solidified the inability of society to counteract it. The dependency on the system allows it to remain in the state of status quo. As will be shown in later chapters, in Canada, the pendulum swing is also stalled. The neo-liberal regime is so highly entrenched in the lives of Canadians, that the perpetuation of the system seems like the only logical move forward. Our dependence on credit cards, mortgages, car loans, the stock market etc. fuels the current regime serving as a major impediment to realizing the counter-movement.

Herman (2012, p. 637) concludes his argument with the hope for an alternative:

"The post-1970s adventure with economic liberalism came very close to accomplishing what Polanyi thought impossible: the disembedding of the economy from society. By tying labour interests to a system of fictitious wealth and short-term value creation, the forces of economic liberalism received the short-term legitimacy it needed. The naturally self-destructive tendencies of the 
self-regulated economy, however, eventually gave way to its many internal contradictions, leaving space for a necessary counter-movement that now seeks to rebuild the relationship between capital and labour, and to rebuild the definition of what is the public interest."

Block (2008) proposes a perspective on why the protective counter movements have been weak throughout the neo-liberal regime. Since the late 1970s, in the United States primarily and generally throughout the world, laisser-faire economics saw many victories; however, counter-movements strong enough to challenge state policies did not make an appearance until 2006. Block finds three contributing factors. The first is the massive investment in the propagation of free market ideals through mass media, think tanks and policy organizations. The second is the unity and support among the elite benefitting from the persistence of laissez faire. And finally, the emergence of the "grassroots activism of the religious right", which is in itself a form of a countermovement, adversely entrenched the conservative attack on the welfare state.

Palacios (2001) on the other hand is more optimistic and expands on the Double Movement in terms of concrete actions being taken to curb market fundamentalism. $\mathrm{He}$ proposes three kinds of initiatives made by means of academic, sociopolitical, and economic forces. In our current times of post-crisis, academia has increased the coverage of alternatives to neo-liberalism. Palacios sees the Montreal-based Karl Polanyi Institute of Political Economy as a potential catalyst to igniting the spark of a new way of thinking. In terms of socio-political responses, Palacios cites twelve movements between 1994 and 2002 ranging from the Chiapas movement in Mexico in 1994 to the infamous WTO protests in Seattle in 1999, among others. Economic responses have seen restrictions on foreign trade and investment and a turn towards regionalism and regional cooperation. The most recent social uprisings in Canada include the Occupy Canada 
Movement and the Quebec Student Movement against the increase in tuition fees are relevant to Palacios' argument that initiatives are in fact underway that set the Double Movement in motion (regardless of how limited the result may be).

Robotham (2009, p. 282) adds to the Afterword of Hann and Hart's Market and Society: the Great Transformation Today with the following: "The broader issue is whether the economic problems of our era may be addressed through a simple choice of restraining or unleashing market relations." For him it seems as though restraining the harmful effects of the market in some aspects and expanding the favourable effects in other aspects is the best course of action. Perhaps Hugo Chavez' "21st century socialism" is the way forward, where the provision of public education, healthcare and antipoverty programs, and a larger economic role for the state, would necessitate the expansion of the market to achieve continued sustainability and prosperity. This concept is viewed as the 'third way', aiming for neither socialism based on central planning nor liberal capitalism, but a more just, autonomous, and regionally based alternative. A combined solution may be the way forward in order to achieve the desired embeddedness and to stay viable in global markets. This is an argument particularly relevant for a country such as Canada that has not yet succumbed to complete laissez-faire market logic.

Baum's (1996) contribution to Polanyian literature evaluates the prevalence of counter-movements. In exploring how a potentially embedded society would look, he (Baum, 1996, p. 51) states:

"If economic activity in an industrial society is again to be embedded in people's social relations, it must promote the cooperative principle at every level of industrial production and foster the informal economy, including local cooperative activity and householding." 
This is precisely what Baum sees as a counter-movement in present-day societies. He witnesses people looking for new forms of economic cooperation, be it within their community or on a broader industrial arena. Some examples that contribute to microsystems of production that deal with local needs would be common kitchens, growing food in the backyard, repairing homes, and micro-lending practices. Cooperative ventures are key for Baum and he demonstrates plenty of evidence of emergence and popularity of such ventures. And while the movement may be threatened by lack of support, these stepping stones may one day contribute to the transformation of the current economic system. The Occupy movement in Canada and around the world is a fitting example of creating alternative micro-systems by which society may operate. The movement started an important conversation of how society could be organized to better represent those without political agency and voice.

\subsection{Polanyi's Influence and Relevance}

"The world we live in today would in many ways have been unrecognizable from the historical vantage point that Polanyi occupied. It is a world characterized by unprecedented levels of interconnectedness, interdependency, rapid change and a concomitant degree of complexity, tension and possibility. Yet, the concepts that Polanyi developed continue to have analytical salience. Much can be drawn from Polanyi's analysis of the great transformation of European societies in order to better understand the current transformation brought by neo-liberal globalization (Castles, Cubas, Kim, Koleth, Ozkul and Williamson, 2011, p. 17).”

Polanyi allows us to have a deeper understanding of the social, political and economic forces encompassing the world order. While stemming from history, the concepts developed by Polanyi are very much well and alive in modern times of neoliberalism and globalization.

"Distinguished economists have joined scholars of other disciplines in drawing attention to the importance of Polanyi's insistence that economic policy must be 
subordinated to broader social objectives. His warning of the perils of subordinating social, cultural and environmental needs to the dictates of the market speak to us as though they were written today (Polanyi-Levitt, 2006, p. 153)."

The significance of Polanyi's work becomes even more prevalent in times of economic crises which occur within the neo-liberal regime. The neo-liberal regime has resulted in more and more disembeddedness through the deregulation of the market system, increased financialization, and the dismantling of the welfare state. The unsustainability of the regime culminated in a global economic crisis of 2008, which is said to be the worst economic disaster since the Great Depression. Polanyi identified the stark utopia of living within a disembedded market system. Wade and Venerso (1998, p. 20) summarizes the argument well:

"Polanyi identified a recurrent pattern in the evolution of capitalism, in which a period of free market policies gave rise to such instability and inequality as to trigger a social and political response, resulting in tighter social and political controls over markets-especially over finance."

\subsection{Thesis Propositions}

The purpose of this thesis is to consider the evidence of Polanyi's theory of the Double Movement in contemporary Canada. The Double Movement represents the pendular swing of the political-socio-economic environment of embeddedness or disembeddedness of the economic forces from those of society. His work in this area results in two key propositions to examine.

\subsection{1 \#1- Disembeddedness}

Following Polanyi, this thesis will examine the proposition that the economic crisis has been the occasion for and accompanied by state policies and actions geared towards further disembedding of the Canadian economy from society. In the chapter that 
follows the evidence of this further disembedding will be presented. This evidence will be accompanied by explanations grounded in neo-liberalism, of why disembedding the economy is a necessary condition for recovery from a crisis induced itself by disembeddedness.

The policies and actions of the federal government will be analyzed including the financial support to the financial sector, the stimulus package and the ensuing austerity measures. It is the first proposition of this thesis that the crisis and the Canadian state's ensuing actions in the form of financial support to financial institutions, stimulus and austerity measures are examples of the further disembedding of the economy in the $21 \mathrm{st}$ century.

\subsection{2 \#2-Societal Response}

Polanyi speaks of the reaction to disembeddedness in the form of social movements aimed at re-embedding the economy in society. This re-embedding as explained by many writers attempting to elaborate on Polanyi, takes many forms including social protest, as well as attempts to build an alternative economy to better serve people through cooperative forms of activity. In Chapter 4, this thesis presents evidence of the development of 21 st century counter-movements in a variety of forms. It is the proposition of this thesis that there are social movements taking shape in Canada and globally in reaction to the disembedding of the economy in a variety of forms. The growth of an anti-austerity discourse and the development of measures of resistance to austerity will be examined, with special reference to the Occupy Movement across Canada and the Quebec Student Movement. 


\subsubsection{Working Argument}

In Canada, since the 1980s neo-liberalism has become entrenched in public discourse and in the practice of government through a range of measures intended to reduce expenditures, taxation, and the size of government and the regulatory functions of government. At the same time, according to the work of Polanyi and those who have written to explain or elaborate his work, a series of counter-movements have been set in motion. Since neo-liberalism is so highly entrenched in the lives of Canadians, the pendulum swing in the other direction is bound to be limited. Nevertheless, the societal forces pushing for greater protection will pave the way for a possible future change in direction from market oriented policies to more sustainable welfare state provisions. These two fundamental propositions drawn from the work of Polanyi will be the subject of investigation in this thesis. 


\section{Chapter: The Economic Crisis of the 21st Century: Disembedding the Economy from Society}

\subsection{Canada's Experience of the Crisis}

Canada fared moderately well in the midst of and in the aftermath of the global economic crisis of 2008. Consequently, Canada is often held up as an exemplar case to other countries around the world. The Finance Minister, Jim Flaherty attributes the resilience to effective regulation, pointing out Canada's finance sector supervisory and regulatory regime. Because Canada experienced a financial crisis in the 1990s, reforms had already been undertaken in previous decades (and not dismantled) that allowed the country to withstand the global crisis of 2008 better than most other developed nations (Roberge, 2010).

Members of the Atlantic Council, Thomson Reuters, the Rotman School of Management at the University of Toronto, and the Embassy of Canada who've participated at a conference entitled The Finance Crisis: Lessons Learned from Canada and the Way Forward specifically describe key strengths that Canada had in the face of the meltdown. First off, the government had a "strong fiscal position, with debt at 28 percent of GDP, compared to 101 percent in the United States, and an average of 62 percent in the European Union (Atlantic Council, 2012, p. 3).” The tight financial regulatory system held banks in a conservative mode of lending. In 2007, the Conservative government allowed the down payment requirement for consumer mortgages to be dropped to zero percent and extended the amortization period to 40 years in order to match the international competition and as a result of pressure from Canadian 
financial institutions; however, shortly thereafter the controls were tightened again as a result of defaulting mortgages in the US. By 2008 zero-down mortgages were almost non-existent and by 2012 these regulations became even more stringent with new protocols from the Office of the Superintendent of Financial Institutions. The result of this was that only five percent of Canadian mortgages were sub-prime in nature (Atlantic Council., 2012). Nevertheless, as throughout the world, Canada had significant exposure to US subprime mortgages through the derivatives they bought, undermining the stability of the financial sector.

The initial shock of 2008 was weathered well, but what came in the aftermath of the initial meltdown has impacted Canada greatly. Recession is officially experienced by a country after two consecutive quarters of negative growth in GDP. In Canada, the official recession took place between October 2008 and July 2009, almost a year after the United States (Campbell, 2009). Manufacturing, which accounts for 15 percent of Canada's output, was particularly hit hard in the spiraling recession, with the automotive sector being the most vulnerable (Arsenault and Sharpe, 2009). As consumer confidence in the market began to plummet, people were not as willing to part with their earnings and savings. Chrysler Canada was experiencing financial loss in the amount of $\$ 1$ million a day, exposing not only the company's profits but also thousands of workers in manufacturing communities such as Windsor to the risk of layoffs (Kiladze, Perkins and Robertson, 2013). Canadian energy producers experienced the traumatic drop in oil prices, and had to quickly scale back their operations. Other natural resource industries such as forestry and mining were also in trouble as the demand for exports dwindled on the world stage. Because the demand for exports dwindled, the country had forgone 
potential profit on many of its exports that were no longer materializing and thus the potential revenue was not contributing to the growth of the GDP. Arsenault and Sharpe (2009) estimate a loss of 13 percent in potential export revenue. Construction was another hard-hit industry resulting from a significant drop in consumer demand. According to Arsenault and Sharpe (2009), corporate profits in Canada fell by 41.7 percent in two quarters of the recession, contributing to a decline in real output of 2.3 percent between the peak of 2008 Q3 and 2009 Q1 and a decline in real GDP per capita by 2.9 percent in the same period. The table below shows a clear dip in the growth of GDP in that period.

Table 8 Gross Domestic Product of Canada, 2000-01 to 2012-13 (millions of dollars)

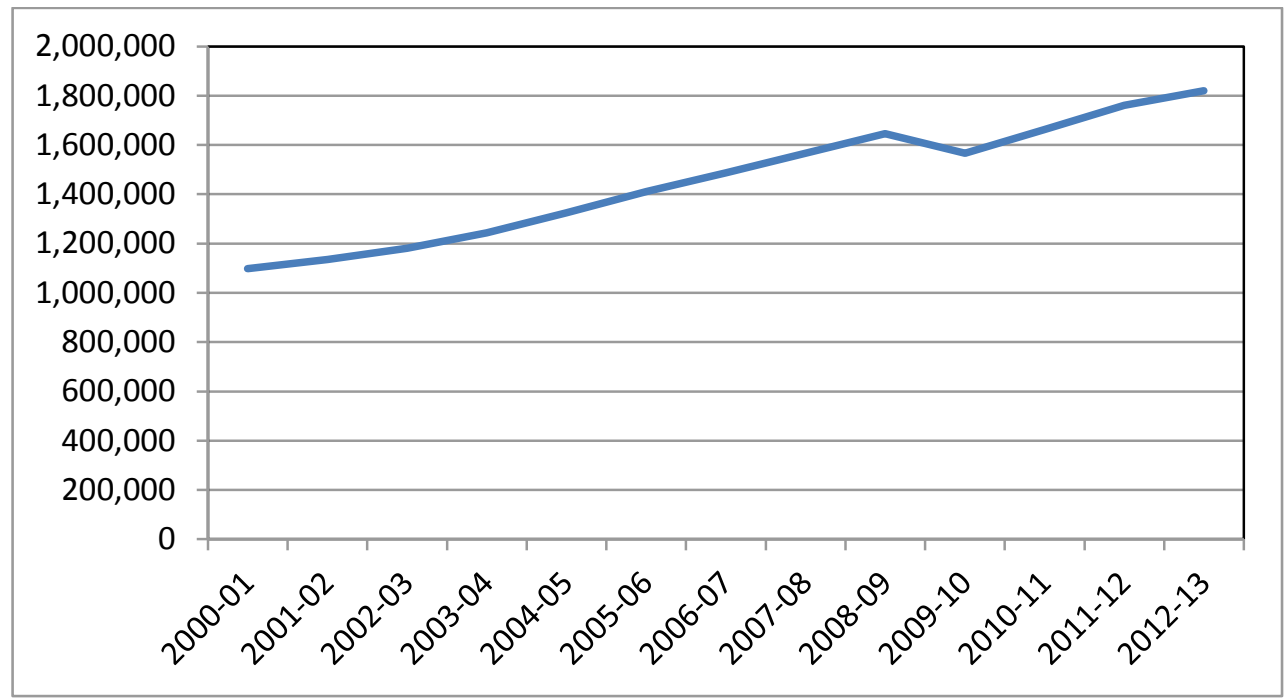

(Department of Finance, Fiscal Reference Tables, 2013)

As the recession progressed, there was no denying that massive layoffs were taking place. Hundreds of thousands of jobs were lost in the process. Arsenault and Sharpe (2009) reported a loss of approximately 406,100 full-time jobs between the onset of the recession in October 2008 and April 2009. In fact, the job loss experienced in 
Canada was proportionately greater than that in the U.S. "Manufacturing communities like Windsor and scores of forestry communities have been devastated (Campbell, 2009, p. 1)." The official unemployment rate rose to 8.4 percent, with more than one-and-ahalf million people looking for work. The manufacturing sector accounted for more than half of the decline in employment and construction accounted for another one-third. These figures point to the fact that lower- to middle-class workers, with lack of transferable skills were affected disproportionately higher than the rest of Canadian industry (Arsenault and Sharpe, 2009). Arsenault and Sharpe (2009, p. 21) state:

"These significant changes, accompany by a now less generous EI system, are likely to translate into a strong relationship between unemployment and poverty. Moreover, given that the social assistance system requires households to draw down their assets significantly before benefiting from assistance, the time needed for households to exit poverty after a lengthy unemployment spell may be even longer than in previous recessions."

In June of 2008, as commodity prices were skyrocketing and oil in particular was moving towards the price point of $\$ 150$ a barrel, the S\&P/TSX composite index hit a record high of over 15,000 . The TSX ended the year at 9,000 or 30 percent lower than at the onset of the collapse of Lehman Brothers. When the TSX bottomed out in February 2009 , it had fallen to 7,566 (50 percent from highest point), wiping out nearly a decade of wealth building (Arsenault and Sharpe, 2009).

Bankruptcies and housing foreclosures were accumulating at a rapid speed and retirement savings in pension plans and other funds declined rapidly. "Between 2008Q2 and 2009Q1, nominal household net worth per capita decreased 9.4 per cent, with aggregate household assets decreasing 6.1 per cent - in particular financial assets (-11.1 per cent) - and aggregate household liabilities increasing 5.0 per cent (Arsenault and 
Sharpe, 2009, p. 11)." While prices for existing houses increased by 29 percent between June 2005 and May 2008, by February 2009, they fell by 6 percent. Because the recession affected short term savings the most, those closer to retirement who had their savings concentrated in equities, lost a significant amount of their assets on paper (Arsenault and Sharpe, 2009). David Denison, the CEO of the Canada Pension Plan Investment Board recounts the losses of retirement savings experienced at the time of the recession:

"We lost 18.6 per cent [in that fiscal year] ... That's billions and billions and billions of dollars. It's well over a $\$ 100$-billion fund, so you do the math... We were heavily criticized for our performance during the period, including on the floor of Parliament by leaders of the opposition parties and other commentators. So this wasn't unnoticed; it's the largest fund in Canada, 18 million peoples' money (Kiladze, Perkins and Robertson, 2013)."

Prior to the onset of the crisis, Canada was undergoing a federal election.

"Parliament was formally dissolved on September 7, 2008, and almost immediately afterwards Wall Street investors were thrown into panic when it became clear that the venerable bank, Lehman Brothers, was in dire straits, and the United States government would not provide the funds necessary for a rescue bailout (Clarke, Scotto and Kornberg, 2011, p. 439)." Throughout the election campaign, Harper's Conservatives were at first in denial that the crisis was in effect. They tried to avoid the issue while the election was going on. It became clear very rapidly that the issue of the economy was not to be swept under the rug and that action was required to stabilize, support, and weather the storm (Campbell, 2009). The next section explores the actions undertaken as a response to the crisis in an effort to reveal the neo-liberal nature of government policy. 


\subsection{Canada's Response to the Crisis}

\subsubsection{Financial Support to Financial Institutions and Stimulus Measures}

At the onset of economic turmoil, Canada took part in the G20 Washington Summit on Financial Markets and the World Economy, aimed at avoiding the economic collapse in 2008-09. In order to counter the devastating effects of the crisis and looming recession, the federal government undertook actions similar to leaders in Washington DC. While the Canadian financial support to financial institutions was not provided to the banks in a straight forward bailout fashion as occurred in the United States, banks still received significant support from government to keep them from going under. The federal government devised a scheme to purchase 'secure' bank mortgages called the Insured Mortgage Purchase Program (IMPP). The federal government Budget of 2009 committed $\$ 75$ billion to buy up these mortgages in $2008-09$ and another $\$ 45$ billion the following year. While the $\$ 75$ billion commitment was announced publically by Stephen Harper and Jim Flaherty, the remaining \$45 billion was simply included in the Budget and not contested (da Silva, 2009). Rashi (2009, p. 38) states, "Although this transaction, implemented through the $\mathrm{CMHC}$, is not taking the form of a direct injection of capital or buyout of toxic assets as government bailout programs in the USA or the UK have done, it is nonetheless a massive handout to the local financial sector." The same author claims that this action was comparable to the $\$ 700$ billion bailout in the US, where the economy is ten times higher than that of Canada.

The government also made available $\$ 200$ billion in support for the banks to be borrowed at low rates if needed, to fill gaps in credit markets through the Emergency 
Financing Framework. According to Campbell $(2009$, p. 8) "It issued new bonds, then gave the money to the banks - either as short-term low-interest loans, or as asset swaps taking over the CMHC-insured mortgages that the banks had on their books" and imposed virtually no conditions on the banks. Campbell (2009) further states that this financial support to financial institutions was 'off the books' since it did not fall into the government's budgetary expenditures. Rather these funds appeared on the financial statements of the Bank of Canada and of CMHC. The government tried to reassure the public that the transactions would not affect public debt "as the borrowings and associated interest costs are matched by an increase in revenue-earning assets (da Silva, 2009, p. 44)." However, da Silva (2009, p. 44) contests these claims made by the government:

"...these are astonishing claims. If the financial assets purchased under the IMPP or the EFF are indeed revenue-earning assets, why are financial institutions attempting either to liquidate them or receive financial support to maintain them?"

Despite the tricky accounting for the provision of financial support to financial institutions, the government's borrowing went from $\$ 13.6$ billion in 2007-08 to $\$ 89.5$ billion in 2008-09 (Campbell, 2009). Furthermore, according to Dobbin (2010), "At the end of 2007 there were $\$ 138$ billion in securitized pools outstanding and guaranteed by CMHC -17.8 per cent of all outstanding mortgages. By June 30, 2009, that figure was $\$ 290$ billion and by the end of 2010 it was $\$ 500$ billion." The government virtually guaranteed or insured all mortgages issued in Canada, eliminating the risk from the banks for lending even in sub-prime situations. Therefore, this seemingly unaffected country had the third highest financial stabilization package among the G7 countries, trailing behind only the US and the UK (Campbell, 2009). 
According to Rashi (2009), the actions were justified as aiming to level the playing field for Canadian banks which were trying to compete internationally with banks that received financial support, as well as being of public interest to prevent a credit crunch which would worsen the state of the economy. However, the hidden agenda was not explained, as it in fact "aims to provide Canadian banks with additional firepower in their efforts to raid troubled competitors south of the border - all at taxpayers' expense (Rashi, 2009, p. 39).

In addition to the bank financial support, the government put forth a stimulus plan for the economy, respecting the countercyclical nature of public expenditure during tough economic times. Over $\$ 63$ billion of government funding ( $\$ 45$ billion of which was federal) was invested by means of Canada's Economic Action Plan ${ }^{1}$, in fiscal years 200910, 2010-11 and 2011-12 (Department of Finance, The Stimulus Phase of Canada's Economic Action Plan, 2012).

"Taxes have been reduced for Canadian families and job-creating businesses; EI benefits were enhanced for the unemployed; thousands of infrastructure projects were completed across the country; significant support was provided for science and technology, industries and communities; and extraordinary actions were taken to improve access to financing (Department of Finance, The Stimulus Phase of Canada's Economic Action Plan, 2012, p. 288)."

Another action undertaken in the wake of the economic crisis was a taxpayerfunded rescue of General Motors (GM), Ford, and Chrysler, which took place in early 2009. The bailout of these manufacturing conglomerates came from both the US and Canadian governments and amounted to $\$ 85$ billion. The intention was to loan the funds

\footnotetext{
${ }^{1}$ Details on The Stimulus Phase of Canada's Economic Action Plan are discussed in the Budgets as the Implementation of Neo-liberalism section below.
} 
in the hopes of preventing massive job losses and destabilization in the manufacturing sector. The Canadian portion of the bailout was funded by both the federal and provincial (Ontario) governments and amounted to $\$ 13.7$ billion (Milke, 2013). The federal portion of the bailout, in the sum of $\$ 9.2$ billion, was accounted for in the $\$ 45$ billion total of Canada's Economic Action Plan.

Combined, these stimulus measures increased the government's deficit (which had been in a surplus position for more than a decade) and debt. By 2011-12, the deficit and debt of Canada stood at $\$ 26.3$ billion or 1.5 percent of the GDP and $\$ 583.6$ billion or 33.2 percent of GDP respectively. If the debt of all provincial governments was to be added to these figures, the 2013 debt would have been $\$ 1.2$ trillion (Department of Finance, Fiscal Reference Tables, 2013).

\subsubsection{Austerity Measures}

As the stimulus phase of the Economic Action Plan was completed, austerity measures kicked in, as they did during the recessions of the 1980s and 1990s. The reality of these austerity politics is that they reinforced further retrenchment of the Canadian welfare state.

As the crisis was generated in the financial sector of the economy, one might expect that in the aftermath of the economic meltdown, the financial sectors might be addressed with stern action and retribution for the burden they placed on public finances. However, the payback for the crisis response came in the form of public financing directed towards financial sector financial support and economic stimulus packages and 
cuts in programs and personnel as opposed to any measures to limit the activities of financial institutions. In fact, during the G20 Summit, which took place in Canada in 2010 , this country was one of the major proponents of public austerity and opponents of any punitive actions against the financial sector. According to the Ontario Federation of Labour (2011, p. 7) "This meeting of world leaders was convened to discuss a global approach to the still reverberating global economic crisis and Canada was a key proponent of an austerity agenda that demanded drastic public spending cuts by 2013.”

Likewise, Bourgeois, Hussey, Saulnier, and Wuite (2012, p. 56) express frustration with the current state of events while looking back at the response to recessions in the 80 s and 90 s:

“...reduce federal government spending in order to reduce deficits. However, public services were not to blame for causing deficits, not in the 1980s, not in the 1990s and not now. Governments have choices about how to achieve fiscal goals. The 1990s cuts contributed to attaining a balanced budget quickly but at serious social and economic cost. The 1990s cuts did a disservice to Canadians and by all accounts, this round of cuts will do the same."

In 2012, both the federal, provincial and territorial governments announced their plans for balancing their budgets. This centralized mandated approach took on the challenge of eliminating the public deficit by adopting cuts over a short period of time and returning to balanced budgets by the end of the decade (Department of Finance, The Stimulus Phase of Canada's Economic Action Plan, 2012). The specific plans for the future of public finances consisted of cuts to funding, elimination of public service jobs, 
and decreased accessibility to social programs such as Old Age Security and Employment Insurance. $^{2}$

Bourgeois, Hussey, Saulnier, and Wuite (2012, p. 19) provide a concise summary of the cuts that have taken place since prior to the onset of the crisis:

"An estimated total of $\$ 8.92$ billion has been cut from federal government programs, staff and operations, across Canada since 2006. Strategic Reviews of each government department's operations between 2007 and 2010 resulted in $\$ 1.82$ billion in spending cuts. In 2010, the federal government froze its operational expenditures until 2014-15, equivalent to a \$2-billion personnel budget cut. The Federal Budget 2012 provides some detail on the third round of cuts, which began with the Strategic and Operating Review announced in 2011. The budget announced cuts of $\$ 5.1$ billion by March 2015. According to the Federal Budget 2012, 19,200 positions will be lost over the next 3 years."

Another important account of the Government of Canada austerity measures came from the office of the Parliamentary Budget Officer on April 25, 2012. Their report indicated that a total of $\$ 10.8$ billion of ongoing reductions from direct program spending. In the report entitled Budget and Expenditure Reporting to Parliament: Strengthening Transparency and Oversight in an Era of Fiscal Consolidation, the three major rounds of cuts were elaborated upon. The Operating Budget Freeze limited federal departments from obtaining additional funding for increases in annual wages, and operating budgets of fiscal years 2011-12 and 2012-13 were frozen at the 2010-11 levels. Strategic Reviews, which started in 2007 required departments to identify their lowest priority programs. The Strategic and Operating Review, also known as the Deficit Reduction Action Plan, aimed at streamlining, consolidating, and modernizing government programs and services, generating $\$ 5.2$ billion of ongoing reductions or $6.9 \%$

\footnotetext{
${ }^{2}$ Details on austerity measures are discussed in the Budgets as the Implementation of Neoliberalism section below.
} 
of the review base of approximately $\$ 75$ billion. According to the Parliamentary Budget Officer's report these reduction measures would greatly affect direct program spending (Barkel and Weltman, 2012).

\subsection{Budgets as the Implementation of Neo-liberalism}

The Federal Budget was the main means by which the government communicated both the stimulus and the austerity measures to the Canadian public. It is important to note that while the stimulus portion of Canada's Economic Action Plan is well documented and clearly presented, the government was not as transparent with the austerity measures and has not been forthcoming with information. To evaluate the impact of government actions in the wake of the global economic crisis of 2008, what follows here is a policy analysis of the Federal Budgets published since 2008 through 2013.

\subsubsection{Financial Support to Financial Institutions and Stimulus Measures}

1. The 2008 Budget (Department of Finance, 2008) includes many proposals focused on investing in people, through student loans and grants, investing in knowledge, supporting communities and traditional industries, protecting the health and safety of Canadians, strengthening partnerships with Aboriginal Canadians, and supporting the vulnerable, such as those with mental health issues, veterans, and children. Since this Budget was published prior to the full onset of the economic crisis, the federal government's commitment still lay somewhat in the sphere of support for the social dimension of the country. Nevertheless, some of the actions undertaken in this Budget were setting the stage for ensuing retrenchment and further disembeddedness. 
Measures taken in the 2008 Budget spanned over three years and amount to $\$ 29.4$ billion, \$23.9 billion of which was dedicated towards tax relief to individuals and businesses. Tax relief was one of the key initiatives of this Budget that was aimed at strengthening the economy:

"The Government took decisive and timely action in the October 2007 Economic Statement to boost confidence and investment by announcing a bold package of tax reductions for individuals, families and businesses of $\$ 60$ billion over this and the next five years. Combined with previous tax relief introduced by the Government, total tax relief over the same period approaches $\$ 200$ billion (Department of Finance, 2008, p. 74).”

2. Budget 2009 (Department of Finance, 2009) acknowledges the persistence of the crisis and puts forth a stimulus proposal. The Budget makes a point of highlighting that consultative efforts were undertaken:

"It has consulted the provinces and territories. It has considered the views of private sector economists, academics, business leaders and thousands of Canadians who participated in on-line consultations. The Minister of Finance also sought advice from his Economic Advisory Council and Members of Parliament from all parties (Department of Finance, 2009, p. 10).”

Furthermore there is "a strong consensus among Canadians that the Government must deliver a potent economic stimulus to encourage growth and restore confidence in our economy (Department of Finance, 2009, p. 10).” This Budget contained a roll out of the two-year Economic Action Plan meant to create or maintain close to 190,000 jobs. The first year of the Plan provided $\$ 30$ billion of stimulus (1.9 percent of GDP), with two year investments projected at $\$ 50$ billion (or 3.2 percent of GDP). Some of the initiatives undertaken include the Canadian Skills and Transition Strategy, the Home Renovation Tax Credit, investment in infrastructure projects, and 
stimulating housing construction. The government also strengthened some of the social services provided to Canadians, such as temporarily increasing Employment Insurance benefit duration from 45 to 50 weeks and keeping its premium rates frozen. It was acknowledged that these measures would create a temporary deficit to protect the economy from the global economic crisis.

Budget 2009 made available $\$ 200$ billion to the financial system through the Extraordinary Financing Framework "to improve access to credit for Canadian consumers and allow businesses to obtain the financing they need to invest, grow and create new jobs (Department of Finance, 2009, p. 15).” Other measures concentrated on the financial sector included providing a standby authority for the Government to inject capital into federally regulated financial institutions, enhancing disclosure and improving business practices in respect, of credit cards issued by federally regulated financial institutions, and prescribing measures to make mortgage insurance more transparent, understandable and affordable, etc. The Fiscal Outlook section of the Budget projected running a deficit in order to implement the Economic Action Plan, but a return to a small surplus in 2013-14 once the economy recovers. There was no mention of the possibility of austerity measures in the event that the economy was not yet strong enough.

3. Budget 2010 (Department of Finance, 2010) set out to reaffirm the second year of the Economic Action Plan, proposed new initiatives that would contribute to job growth and the strengthening of the economy, and outlined measures to bring the government's finances back to balance over the medium term. On the first point, the 
Budget outlined the creation of 135,000 jobs as a result of 16,000 projects under the Economic Action Plan. On the second point, \$19 billion of federal and \$6 billion of provincial, territorial, and municipal stimulus were put forth in addition to the $\$ 30$ billion of federal funds committed through Budget 2009, amounting to a total of \$64 billion of total government funding dedicated to this stimulus plan. Through these stimulus measures, Canada saw more personal tax relief to support growth and job creation, strengthening of benefits for the unemployed, provision of training opportunities for workers, and continuous modernization of infrastructure among other initiatives. The third point is discussed in greater detail in the subsequent section.

4. According to the 2011 Budget (Department of Finance, 2011), the Economic Action Plan contributed over $\$ 60$ billion to the economy of both federal and provincial funding, served to undertake 28,500 projects and created about 540,000 jobs since July 2009. The government continued to claim that "it will not raise taxes or cut transfers to persons, including those for seniors, children and the unemployed, or transfers to other levels of government in support of health care and social services, Equalization, and the gas tax transfer to municipalities (Department of Finance, 2011, p. 156)." Other measures announced in this budget focused on 'The Next Phase of Canada's Economic Action Plan — A Low-Tax Plan for Jobs and Growth'. Supporting job creation, supporting families and communities, investing in innovation, education and training preserving Canada's fiscal advantage were the key areas of focus for the 2011 Budget. 
5. Budget 2012 (Department of Finance, Jobs Growth and Long-Term Prosperity: Economic Action Plan, 2012) incorporated The Stimulus Phase of Canada's Economic Action Plan: A Final Report to Canadians, elaborating on government investments to support the economy in the wake of the economic crisis. Of the $\$ 45$ billion of federal funding, a total of $\$ 6.9$ billion went into reducing the tax burden for Canadians, $\$ 8.4$ billion was dedicated to supporting the unemployed, $\$ 14.5$ billion was dedicated to building infrastructure to create jobs, $\$ 3.3$ billion advanced Canada's knowledge economy and created better jobs, and $\$ 13.0$ billion was used in support of industries and communities. Moreover, 30,200 infrastructure projects were completed boosting both the economy and unemployment. The report states that by March 2012, 610,000 more jobs were available in Canada than in July of 2009, allowing Canada to have the strongest job growth in G7. In terms of tax reductions, the majority of the $\$ 6.9$ billion of relief went into personal income tax relief for all taxpayers, specifically targeting low and middle-income families and into enhancing the Working Income Tax Benefit, which was effectively doubled since its introduction in Budget 2007. Increases to the National Child Benefit supplement and the Canada Child Tax Benefit and targeted relief for seniors were also incorporated into tax reductions to a lesser degree. In terms of tax relief for businesses, the report states the following:

"In 2007, Parliament passed a bold tax reduction plan that lowered the federal general corporate income tax rate from 22.12 per cent in 2007 (including the corporate surtax that was eliminated in 2008) to 15 per cent in 2012. The stimulus phase of the Economic Action Plan built on these corporate income tax reductions to help position businesses to weather the effects of global economic challenges, invest in Canada, and spur innovation and growth - thereby creating more and 
better-paying jobs for Canadian workers (Department of Finance, Jobs Growth and Long-Term Prosperity: Economic Action Plan, 2012, p. 300).”

The report elaborates that "Including measures in the stimulus phase of the Economic Action Plan, the Government has introduced business tax relief totaling roughly $\$ 60$ billion over 2008-09 and the following five fiscal years (Department of Finance, Jobs Growth and Long-Term Prosperity: Economic Action Plan, 2012, p. 301)." In terms of support for the unemployed, Employment Insurance benefits were strengthened at the expense of $\$ 2.9$ billion, the majority of which included an extra five weeks of benefits, and enhancing the availability of training totaling $\$ 1.8$ billion. It cost the government an additional $\$ 3.6$ billion to maintain the Employment Insurance rates frozen for two years. Supporting industries such as the auto sector, forestry, tourism, and shipbuilding and supporting communities cost the government $\$ 11.5$ billion and $\$ 1.6$ billion respectively. Below is a table summarizing key initiatives and their total costs as pertained to the stimulus plan. 
Table 9 Canada's Economic Action Plan - Results Achieved, 2009-10 to 2011-12 (millions of dollars)

\begin{tabular}{|c|c|c|c|c|}
\hline & $2009-10$ & $2010-11$ & $2011-12$ & Total \\
\hline Reducing the Tax Burden for Canadians & 3,020 & 3,180 & & 6,200 \\
\hline Helping the Unemployed & 3,348 & 5,005 & & 8,353 \\
\hline Building Infrastructure to Create Jobs & 6,021 & 7,462 & 1,051 & 14,534 \\
\hline $\begin{array}{l}\text { Advancing Canada's Knowledge Economy } \\
\text { and Creating Better Jobs }\end{array}$ & 1,550 & 1,469 & 250 & 3,269 \\
\hline Supporting Industries and Communities & 10,979 & 2,023 & & 13,003 \\
\hline Total federal stimulus measures & 24,918 & 19,140 & 1,301 & 45,359 \\
\hline Leveraged provincial and territorial actions & 8,553 & 7,679 & 2,164 & 18,395 \\
\hline Total Economic Action Plan stimulus & 33,471 & 26,819 & 3,465 & 63,755 \\
\hline \multicolumn{5}{|c|}{$\begin{array}{l}\text { Notes: Totals mey not add due to rounding. Amounts for } 2009-10 \text { and } 2010-11 \text { are actual cash expendtures, while } \\
\text { amounts for } 2011-12 \text { refled estimated expenditures only for the four extended infrastrudure progams. As a result of } \\
\text { the extension of these progarms, some funds orignally planned for } 2010-11 \text { will be recorded in } 2011-12 \text {. Final numbers } \\
\text { will be released in the Public Accounts of Canada in Fall } 2012 \text {. }\end{array}$} \\
\hline
\end{tabular}

(Department of Finance, Jobs Growth and Long-Term Prosperity: Economic Action Plan, 2012, p. 290)

\subsubsection{Austerity Measures}

1. Budget 2008 stated the government's commitment to "carefully managing spending to ensure programs and services are efficient, effective, aligned with the priorities of Canadians, and affordable over the long term (Department of Finance, 2008, p. 9)." Within this scope, Strategic Reviews implemented in 2007 were discussed in the Budget, contributing to cuts of $\$ 386$ million of low-priority, lower-performing or programs that were redundant and therefore no longer needed. Also within the same parameters, the previous Budget committed to keeping "the rate of growth of program spending, on average, below the rate of growth of the economy (Department of Finance, 2008, p. 68)." This allowed spending in relation to the growth of the economy to remain at a level below 2004-05. 
2. The 2009 Budget announced the results of another Strategic Review, which examined \$25 billion (27 percent) of direct program spending. Identified savings for fiscal years 2009-10, 2010-11, 2011-12 amounted to \$349 million, \$449 million and \$586 million respectively. As was the case in Budget 2008, these savings were reinvested in other priorities of the government. While the exact programs into which these savings were reinvested are hard to identify, department's main or supplementary estimates requirements were usually lowered by the amount corresponding with savings (Department of Finance, 2008).

3. The increase in the stimulus announced in Budget 2010 (Department of Finance, 2010) contributed to a longer period of deficits than was stipulated in Budget 2009. More specifically, the government was still anticipating a small deficit in 2014-15 as opposed to a return to surplus in $2013-14$ as was originally planned. To return to a fiscal balance, the Budget proposed to wind down the Economic Action Plan as planned, restrain government spending, in turn saving $\$ 17.6$ billion over five years, and to "undertake a comprehensive review of government administrative functions and overhead costs in order to identify opportunities for additional savings and improve service delivery (Department of Finance, 2010, p. 111).” The $\$ 17.6$ billion in savings was to be achieved through targeted measures such as restraining growth in spending on national defence spending and on the international assistance envelope, as well as containing the administrative costs of government, committing to more savings through Strategic Reviews, and closing tax loopholes to ensure 
integrity of the tax system. It was stated that the government will not be raising taxes or cutting major transfers to persons or other levels of government to return to balanced books. This Budget set the environment for austerity measures yet to come.

The 2011 Budget (Department of Finance, 2011) claims to be on track towards achieving a surplus position by 2015-16 at the latest. "The first cycle of strategic reviews has resulted in $\$ 11$ billion in savings over seven years and more than $\$ 2.8$ billion in ongoing savings (Department of Finance, 2011, p. 18)." While the Strategic Reviews were to be completed in 2011-12, the Strategic and Operating Review was first introduced through this Budget. This latter review was reported as contributing $\$ 4.0$ billion of annual savings by $2014-15$ and onwards. The table below represents savings achieved through Strategic Reviews.

Table 10 Strategic Reviews - First Four-Year Cycle, 2008-09 to 2014-15 (millions of dollars)

\begin{tabular}{|c|c|c|c|c|c|c|c|c|}
\hline & $\begin{array}{l}2008- \\
2009\end{array}$ & $\begin{array}{l}2009- \\
2010\end{array}$ & $\begin{array}{l}2010- \\
2011\end{array}$ & $\begin{array}{l}2011- \\
2012\end{array}$ & $\begin{array}{l}2012- \\
2013\end{array}$ & $\begin{array}{l}2013- \\
2014\end{array}$ & $\begin{array}{l}2014 \\
2015\end{array}$ & Tota \\
\hline & \multicolumn{8}{|c|}{ (millions of dollars) } \\
\hline 2007 strategic reviews & 199 & 311 & 386 & 395 & 403 & 403 & 403 & 2,500 \\
\hline 2008 strategic reviews & & 349 & 449 & 586 & 598 & 604 & 604 & 3,190 \\
\hline 2009 strategic reviews & & & 152 & 248 & 287 & 288 & 288 & 1,262 \\
\hline 2010 strategic reviews & & & & 194 & 271 & 569 & 525 & 1,560 \\
\hline Subtotal & 199 & 660 & 987 & 1,423 & 1,559 & 1,864 & 1,820 & 8,511 \\
\hline $\begin{array}{l}\text { Departrrent of } \\
\text { National Defence }\end{array}$ & & & & & 525 & 1,000 & 1,000 & 2,526 \\
\hline Total Savings & 199 & 660 & 987 & 1,423 & 2,084 & 2,864 & 2,820 & 11,037 \\
\hline
\end{tabular}

(Department of Finance, 2011, p. 219) 
4. Budget 2012 (Department of Finance, Jobs Growth and Long-Term Prosperity: Economic Action Plan, 2012) was where austerity measures were most evident for Canadians. The Strategic and Operating Review announced in the previous Budget translated into annual savings of $\$ 5.2$ billion ( 6.9 percent) which were identified by the federal government through the review of the base spending of approximately $\$ 75$ billion. The Budget made the point that these cuts were modest compared to other countries undergoing similar austerity measures, and moreover they were radically different from the Program Review cuts of mid-1990s which undermined health care, education, and social spending transfers. A small surplus was projected for fiscal year 2015-16. While the issue of the impact of austerity measures on the workforce was not mentioned in the Budget in Brief version of the federal budget, the Budget Plan goes into details of these cuts. According to the Budget Plan, federal employment was to be reduced by about 19,200 or 4.8 percent of the total workforce population over a three year period, 600 of which were to be at the executive level. The Budget continues to reiterate that the Program review cuts of mid-1990s were much more severe than those of the current austerity program. It was also stated that "between 1998 and 2011, federal employment grew by approximately one-third, or 95,000, from just under 300,000 in 1998 to just under 400,000 in 2011 (Department of Finance, Jobs Growth and Long-Term Prosperity: Economic Action Plan, 2012, p. 221)." The Annex on Responsible Spending went into greater detail of how the reductions were to be achieved. While some departments do provide brief details on the programs to be impacted by the cuts, the explanations were mostly vague, general and broad. Departments used phrases such 
as 'eliminating red tape', 'improve service delivery', 'consolidate and streamline', and 'leverage technology' without dwelling into specifics of how and where the impacts would be felt. The table below provides a breakdown of the $\$ 5.2$ billion in savings by department. 
Table 11 Planned Reductions in Departmental Spending, 2012-13 to 2014-15 and ongoing (millions of dollars)

\begin{tabular}{|c|c|c|c|c|c|c|c|}
\hline Parfolio & $2012-13$ & $2013-14$ & $2014-15$ & Ongoing & $\begin{array}{l}\text { Review } \\
\text { Base }\end{array}$ & $\begin{array}{r}\text { Per Cent } \\
\text { of Revien } \\
\text { Base }\end{array}$ & $\begin{array}{r}\text { Per Ceat of } \\
\text { Total } \\
\text { Progran } \\
\text { Spending' }\end{array}$ \\
\hline $\begin{array}{l}\text { Aborigina Affairs and } \\
\text { Northern Development }\end{array}$ & 26.9 & 60.1 & 165.6 & 165.6 & $6,223.2$ & 2.7 & 0.06 \\
\hline Agerts of Parliament & 8.3 & 8.8 & 16.4 & 16.4 & - & - & 0.01 \\
\hline Agriculture and Agrifood & 17.1 & 168.5 & 309.7 & 309.7 & $3,092.3$ & 10.0 & 0.12 \\
\hline Canada Reverue Agency ${ }^{2}$ & 14.8 & 87.0 & 225.4 & 253.1 & $3,641.2$ & 6.9 & 0.09 \\
\hline Citizenship and Immigration & 29.8 & 65.2 & 84.3 & 84.3 & $1,581.5$ & 5.3 & 0.03 \\
\hline Ermironment & 19.5 & 56.4 & 88.2 & 88.2 & $1,062.2$ & 8.3 & 0.03 \\
\hline Finance ${ }^{2}$ & 20.6 & 32.6 & 34.6 & 38.6 & 229.4 & 16.8 & 0.01 \\
\hline Fisheries and Ooeans & 3.8 & 13.4 & 79.3 & 79.3 & $1,360.1$ & 5.8 & 0.03 \\
\hline $\begin{array}{l}\text { Foreign Affairs and } \\
\text { International Trade }\end{array}$ & 72.4 & 116.6 & 169.8 & 169.8 & $1,916.2$ & 8.9 & 0.06 \\
\hline Health & 111.7 & 218.5 & 309.9 & 309.9 & $4,811.7$ & 6.4 & 0.12 \\
\hline Heritage & 52.2 & 130.7 & 191.1 & 191.1 & $2,773.7$ & 6.9 & 0.07 \\
\hline $\begin{array}{l}\text { Human Resoumces and } \\
\text { Skills Development }\end{array}$ & 10.6 & 64.7 & 286.7 & 286.7 & $7,589.8$ & 3.8 & 0.11 \\
\hline $\begin{array}{l}\text { Industry } \\
\text { Internationa Assistance }\end{array}$ & 89.2 & 182.7 & 217.3 & 217.3 & $3,454.4$ & 6.3 & 0.08 \\
\hline Envelope & 180.7 & 242.1 & 377.6 & 377.6 & $3,896.8$ & 9.7 & 0.14 \\
\hline Justice & 21.2 & 69.0 & 76.9 & 76.9 & 898.3 & 8.6 & 0.03 \\
\hline National Defence & 326.8 & 706.1 & $1,119.8$ & $1,119.8$ & $15,069.0$ & 7.4 & 0.42 \\
\hline Natura Resources & 68.3 & 86.0 & 108.3 & 108.3 & $1,079.6$ & 10.0 & 0.04 \\
\hline Priwy Council Office & 3.7 & 6.5 & 12.2 & 12.2 & 102.6 & 11.9 & 0.00 \\
\hline Public Satety & 179.4 & 370.7 & 687.9 & 687.9 & $6,940.6$ & 9.9 & 0.26 \\
\hline Public Service Commission & 2.2 & 4.5 & 9.0 & 9.0 & 89.9 & 10.0 & 0.00 \\
\hline $\begin{array}{l}\text { Public Works and } \\
\text { Governmert Serwices }{ }^{2}\end{array}$ & 1.5 & 28.1 & 85.3 & 177.6 & $1,848.6$ & 9.6 & 0.07 \\
\hline $\begin{array}{l}\text { Regiona Development } \\
\text { Agencies }\end{array}$ & 26.7 & 73.4 & 86.9 & 86.9 & 996.2 & 8.7 & 0.03 \\
\hline Shared Services Canada & 74.7 & 104.5 & 150.0 & 150.0 & $1,493.4$ & 10.0 & 0.06 \\
\hline Transport & 63.4 & 97.2 & 152.6 & 152.6 & $1,428.8$ & 10.7 & 0.06 \\
\hline Treassy Board & 10.4 & 18.6 & 30.2 & 30.2 & 281.1 & 10.7 & 0.01 \\
\hline Veterans Aftairs ${ }^{2}$ & 36.1 & 49.3 & 66.7 & 36.9 & $3,487.6$ & 1.1 & 0.01 \\
\hline Total Portfolo Savings & $1,472.1$ & $3,061.2$ & $5,141.5$ & $5,235.7$ & $75,348.1$ & 6.9 & 1.9 \\
\hline \multicolumn{8}{|c|}{ 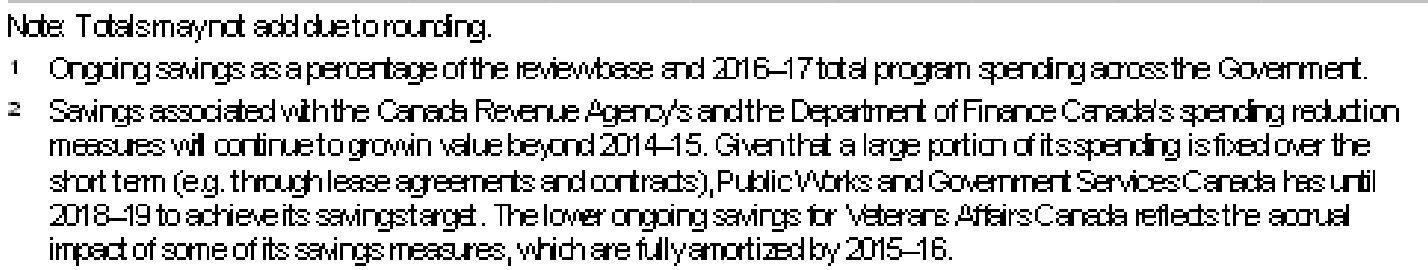 } \\
\hline
\end{tabular}

(Department of Finance, Jobs Growth and Long-Term Prosperity: Economic Action Plan, 2012, p. 213) 
Another measure that has an impact on one of the only remaining universally provided social program was announced in this Budget. The age of eligibility for Old Age Security was raised from 65 to 67 starting in 2023.

5. "To ensure that Canada is well positioned to withstand any future economic shocks and address the future priorities of Canadians, Economic Action Plan 2013 sets out a low-tax plan to eliminate the deficit and return to balanced budgets by 2015-16 (Department of Finance, Jobs Growth and Long-Term Prosperity, 2013, p. 4).” The 2013 Budget simply reinstated the plans to return to balanced budgets by $2015-16$ and to do so without raising taxes or cutting transfers to persons, or transfers to other levels of government in support of health care and social services. In addition to austerity measures undertaken in the earlier Budget, a few new initiatives were proposed to lower government spending, including reductions in travel expenditures and targeted operations cuts in the Canada Revenue Agency and Fisheries and Oceans Canada.

As stipulated in the previous section, the stimulus measures of the response to the crisis sharply increased the country's deficit to $\$ 26.3$ billion or 1.5 percent of the GDP and debt to $\$ 583.6$ billion or 33.2 percent of GDP by 2011-12. These increases are significant in comparison to the 2007-08 figures of $\$ 9.6$ billion of surplus (an increase of $\$ 35.9$ billion in deficit) and $\$ 457.6$ billion of debt (an increase of $\$ 126$ billion) (Department of Finance, Fiscal Reference Tables, 2013). 


\subsection{Disembeddedness: Analysis of the Response to the Crisis, 2008-2013}

While earlier sections of this chapter presented the experience of Canada from the onset of the global economic crisis, its stabilization through financial support to financial institutions and stimulus measures, and an attempt to return to status quo through austerity measures, this section will aim to provide evidence that state policies and actions following the crisis were geared towards the further disembedding of the Canadian economy from society. To conduct this analysis, state actions in the period between 2008 and 2013 will be evaluated in the framework of the neo-liberal agenda through the Polanyian theoretical lens.

Thinking logically about the impact an economic crisis might have on state actions, one might expect a move away from neo-liberalism, be it slight or significant. However, in the wake of the 2008 crisis, states wanted to quickly revert to status quo without deviating from their neo-liberal principles. Regulations were not imposed on the financial sector as one might envision and greater deregulation and the self-regulating market are still valued above all. Reductions in taxes were undertaken and the public sector was made smaller and more 'efficient'. These actions were justified within the politics of austerity, in which governments have been trying to convince labour since the onset of the 1970s that public finances should not be reconciled through higher revenue gathered from taxation, but rather through the elimination of public debt and through reductions in public expenditures vis-a-vis cuts to programs.

Thus a clear link is made between the events that ensured the economic meltdown and the further dismantling of the welfare state and entrenchment of the neoliberal paradigm, or in Polanyi's terms, the disembedding of the economy from society. 


\subsubsection{Financial Support to Financial Institutions and Stimulus Measures}

Billions of dollars of financial support provided to financial institutions in Canada through the Insured Mortgage Purchase Program and the Emergency Financing Framework are the first point of contention. Da Silva $(2009,41$, p. 44) characterizes this as "one of the largest transfers of wealth in Canadian history to private interests" and "one of the greatest financial raids of public funds to subsidize financial institutions in Canadian history." The first announcement of shifting funds through the Insured Mortgage Purchase Program came a mere four days prior to the 2008 Federal Election. With the perfect opportunity in the face of the looming election, neither the Liberal Party nor the New Democratic Party contested the proposal. This action did not generate the needed public debate about "swapping hundreds of billions of dollars for questionable assets held by Canada's banks (da Silva, 2009, p. 41)." In fact Bay Street lobbyists continued to push for the Emergency Financing Framework to be expanded beyond \$200 billion. Da Silva (2009, p. 44) argues that "The consequence of this financing will be to massively expand the public debt through non-budgetary financial supports. The servicing of this debt will build pressure for further mass privatization and further gutting of Canadian social programs." With such dire consequences, he is bewildered at how little public attention these measures have received. On the other hand, it is understandable that the public may have been misled about the nature of these purchases since the government claimed there would be no effect on public debt as a result of the revenue-generating nature of the purchased assets. Frustration is also directed at the fact that the surge of public funding into the banks will allow them "to consolidate their position and fund the acquisition of several U.S. financial institutions (da Silva, 2009, p. 
45)." Da Silva (2009) sees this as deliberate action by the Canadian state to support monopoly capital interest in the financial sector, while at the same time undermining public finances required for social program provision.

"The economic crisis is demonstrating that there is no shortage of resources in the Canadian economy, or that might be mobilized and put at the disposal of the Canadian state, to meet the needs of capitalist interests in Canada. But there is a lack of resources being put toward the social and economic challenges that the majority of Canadians are facing in the current economic crisis. There is, moreover, a shortage of political organization among the Canadian working classes (da Silva, 2009, p. 45)."

While capital and the financial sector were provided with timely financial support packages, government actions were not as forthcoming in rescuing individual workers. This is particularly evident in the US, where the crisis striped many working people of their home equity and foreclosures were rampant. While Obama quickly made sure that Wall Street was fully protected by bailout funding, the unfortunate individuals who lost their homes received no concessions. State action was quick to respond to the needs of capital in bailing out financial institutions engaged in risk-taking and speculation, while at the same time, it gave virtually no concessions to labour who experienced similar hardships on a personal level (Rehman, 2010).

The federal government provided $\$ 9.2$ billion of loans to GM and Chrysler in an effort to avoid bankruptcies and liquidations in the companies so key to the Canadian manufacturing sector. While the terms of these loans are complex, Milke (2013) claims that large portions of them have been written off and will never be repaid. "The Canadian Taxpayers' Federation noted that between 1982 and 2005, Ottawa handed out more than $\$ 18.2$ billion to corporations, of which only $\$ 7.1$ billon was repayable, and 
only $\$ 1.3$ billion was ever repaid (National Post, 2009)." This stimulus action is another illustration of public funding flowing in the direction of private interests.

Furthermore, with the inclusion of the accords provided in the Economic Action Plan, "the Government has introduced business tax relief totaling roughly $\$ 60$ billion over 2008-09 and the following five fiscal years (Department of Finance, Jobs Growth and Long-Term Prosperity: Economic Action Plan, 2012, p. 301).” The $\$ 60$ billion accorded to the corporate sector amounts to almost ten times the $\$ 6.2$ billion in reducing the tax burden for Canadians as part of the Economic Action Plan. The $\$ 60$ billion is greater than the $\$ 45$ billion of federal funding allocated for the stimulus package. These actions point to the neo-liberal nature of policies in Canada, which are highly skewed towards benefiting the corporate elite and capital rather than average citizens and labour.

Some may argue that the financial support to financial institutions and stimulus attempts may be seen as steps towards embeddedness witnessed through a more prominent presence of government in the economic sphere. Also with the strengthening of Employment Insurance through Budget 2009 and stimulus spending that provided tax credits and increased job opportunities in sectors that have been hit hardest by the recession, one may assume that the government is acting in a way to protect and provide for society in harsh economic times. While this may be the case, most of the benefits of the financial support to financial institutions and stimulus went to the corporate sector. Even if the whole federal share of $\$ 45$ billion went to support society in the wake of the recession, corporate interests received a much larger share of concessions. Financial support of financial institutions, support for the auto industry, and cuts in corporate taxes 
are actions that are ultimately aligned with the neo-liberal ideology and contribute to the disembeddedness of the economy from society in Canada.

\subsubsection{Austerity Measures}

\subsubsection{Public Expenditures}

Despite the evidence of contradiction, the response to the crisis around the world has been austerity directed towards state spending. Cutting government expenditures goes against the Keynesian economic principles of weathering out a recession.

Following the countercyclical principles, state spending should be increasing at the time of a recession to boost productivity and restore growth. "In the short to medium run, fiscal consolidation - whether in the form of cutting government spending or increasing revenues - results in lower output and employment, which means lower tax collection, higher deficits, and escalating debt relative to GDP (Tyson, 2012)." Tyson (2012) points out that "the deterioration in public finances was a symptom of the crisis, not its cause"; she further stipulates that it is not a new phenomenon but has been witnessed through history - government debt increases significantly as a result of economic recessions caused by the booms and busts of the financial sector. Public debt has risen drastically as a result of financial support to failing financial institutions and high levels of fund injection into the economy to prevent further sliding into a recession. Mahnkopf (2012, p. 475) explains that "governments are forced into debt on behalf of private financial institutions." So not only was government debt not the cause of the crisis, but austerity measures treat the reduction of public debt as a solution out of a recession. The conclusions that stem from this turn of events point to the fact that "the austerity agenda 
has less to do with economics or even good fiscal management than with ideology (Labonte, 2012, p. 260)." The austerity project is another tool with which the propagation of neo-liberalism and even further scaling back of the welfare state takes place and is legitimized. While the federal government realized the culprit of the crisis to have been the deterioration of housing loans in the US, cutting government expenditures is nevertheless the cure.

Alternatives to austerity also exist within the fiscal policy of a given nation. A slower pace of debt reduction could be adopted or the reduction of the deficit can be approached via tax increases. These alternatives were not pursued by the Harper government and austerity in the form of cuts to public expenditures came to the forefront of ensuring the propagation of the neo-liberal agenda and thus disembeddedness in Canada.

The cost of austerity falls disproportionately on labour as opposed to capital. While the crisis was mainly a result of risk-taking by the financial sector and appropriation by capital, the recovery leads to a curtailing of the public spending which serves primarily labour. The financial sector has remained mainly untouched. The lack of any reprimand or limits on the financial sector points to the extent of disembeddedness of the economy in Canada. While the culprit of the crisis is left undamaged (with the exception of a few regulations that were imposed on the financial sector such as reverting to earlier mortgage regulations), it is society that must absorb the damage that comes from self-regulating markets. Furthermore, Ontario Federation of Labour (2011, p. 6) states: 
"Once again, the excesses of the markets will damage the real economy. This should remind us that little or nothing has been done to implement the financial re-regulation agenda that was briefly given serious consideration in the aftermath of the 2008 stock market crash. Market mayhem continues because governments are still in thrall to a financial sector, which profits from patently parasitic and damaging speculation."

Despite the inability of the neo-liberal system to sustain itself without compromising people around the globe with the ups and downs of the cycles, the response to the crisis has been restraint of the economic sphere. Dale (2012) argues that although state intervention has played a bigger role in this recovery, the neo-liberal agenda has been 'hardwired' into the institutions and systems on which modern societies run. Therefore, deviating the recovery from a strictly economic focus will likely be a fruitless endeavour. Rather than deal with the underlying problem and root cause of the crisis which is lodged in the financial system, the public sector and labour are bearing the brunt of the challenging times. The neo-liberal consensus on the world stage continues to go unchallenged in any significant way.

Public spending, on the other hand, has been cut in a variety of ways such as the elimination of or reduction of social programs, the elimination of government jobs and the scaling back of public salaries and benefits. However, austerity doesn't stop there; it also aims to weaken the bargaining power of labour through more restrictive legislation. Colatrella (2011, p. 84) sees the austerity project as further entrenching the interests of the holders of capital and says it "is a central part of the program of ruling-class unity, needed to overcome the counter-tendencies of democracy and working class power and organization, of resistance to expropriation and exploitation, so as to extend the sphere of the unified average rate of profit and to further concentration and centralization." Campbell (2012) compares the current austerity project to the policies enforced by the 
IMF on developing, emerging and reconstructing states around the world. Now however, attention is directed towards the middle and working classes of the industrialized nations, resulting in the further consolidation of the power of the elite. The crisis is being dealt with in a way that not only preserves their wealth and power but that makes it more potent. The author also refers to the austerity project as "a one-sided class war against the poor (Campbell, 2012, p. 246).” The bleak reality is summarized by Streeck (2011, p. 23) and by Ontario Federation of Labour (2011, p. 3):

"The average citizen will pay - for the consolidation of public finances, the bankruptcy of foreign states, the rising rates of interest on the public debt and, if necessary, for another rescue of national and international banks - with his or her private savings, cuts in public entitlements, reduced public services and higher taxation."

"The world's ruling elite moved to implement an "austerity agenda" using the crisis as an ideological baton with which they hammer ordinary people into believing there is no alternative to slashing public services, selling off public assets, shredding the social safety net, laying off public sector workers, increasing user fees for public services while simultaneously reducing corporate taxes."

The Parliamentary Budget Officer (Barkel and Weltman, 2012) estimates a total of $\$ 10.8$ billion of ongoing reductions in direct program spending as austerity measures. In terms of percentage of Gross Domestic Product, austerity measures fall to 5.5 percent in 2016-17 relative to an average of 8.2 percent during the 1961-62 to 2010-11 period. These substantial figures demonstrate the persistent attack on public spending. As public spending is the pinnacle of a strong and solid welfare state, continuous reductions and cuts to government finances provide strong evidence of further disembeddedness in the wake of an economic downturn.

In terms of the programs and services affected by the cuts, the government keeps reassuring the public that the cuts target the "back office" functions and that services will 
be generally left untouched. However, unfortunately, this is not the reality witnessed to date. There is a general move towards automated service delivery, limiting when, where, and how the programs and services could be used by the public (Bourgeois, Hussey, Saulnier, and Wuite, 2012)." Furthermore, MacDonald (2013) did a thorough examination of the 2013-14 Reports on Plans and Priorities and determined that out of major government departments, cuts are in fact affecting programs that provide direct services. An example of such cuts is a 62 percent reduction to the Social Development program supporting homelessness initiatives within Employment Services and Development Canada. Furthermore, the table below demonstrates that social programs were the ones that experienced the second hardest hit through austerity measures, emphasizing that governmental priorities lie with the elimination of deficit and debt as opposed to the strengthening and improvement of the country's social programs.

Polanyi's quest for social justice would not hold up in this situation; in the last few years those most vulnerable in society have been bearing and will continue to bear the costs of austerity. 


\begin{tabular}{|l|r|}
\hline \multicolumn{1}{|c|}{ Sector } & $\begin{array}{r}\text { Ongoing Savings } \\
\text { (\$000s) }\end{array}$ \\
\hline International, Immigration, and Defence Programs & $\mathbf{1 , 7 1 4 , 8 0 0}$ \\
\hline Social Programs & $\mathbf{7 8 3 , 5 0 0}$ \\
\hline General Government Services & $\mathbf{7 1 6 , 1 0 0}$ \\
\hline Security and Public Safety Programs & $\mathbf{6 8 8 , 0 0 0}$ \\
\hline Environmental Government Services & $\mathbf{5 5 1 , 1 0 0}$ \\
\hline Industrial, Regional, and Scientific-Technological & $\mathbf{2 7 0 , 8 0 0}$ \\
\hline Support Programs & $\mathbf{2 2 2 , 2 0 0}$ \\
\hline Cultural Programs & $\mathbf{1 5 3 , 8 0 0}$ \\
\hline Transportation Programs & $\mathbf{7 8 , 5 0 0}$ \\
\hline Justice and Legal Programs & $\mathbf{5 , 1 7 8 , 8 0 0}$ \\
\hline
\end{tabular}

(Barkel, Jacques and Stanton, 2012)

\subsubsection{Employment}

While the official numbers of federal public sector job losses were stated at 19,200 , if we were to add the losses experienced during the 2007-10 Strategic Reviews of 6,300 and further 4,100 positions as a result of the 2010 Budget Freeze, the total tally comes to 29,600 . Out of the 19,200 , the majority of the job losses were taking place in 2013-14 and 2014-15 with losses of 13,200 and 9,500 positions respectively. This brought federal government employment from 376,000 to 347,500 positions over a fiveyear period starting in 2012 . Nearly 30,000 jobs is a very substantial amount, representing approximately an 8 percent cut. Another estimate was established for private job losses resulting from cuts in funding. The impact was estimated at 40,825 jobs across Canada. Coupled with nearly 30,000 jobs cut directly in the public service, 
Canada lost approximately 70,000 as a direct result of the austerity project (MacDonald, 2013).

Within the welfare state, public employment has traditionally represented a strong and stable economy. These jobs have served as pillars of stability, balancing out the unpredictability of the private market. With fewer jobs available in the public realm, the entrenchment of the neo-liberal ideology is propagated, while the principles of stability and reliability that were present in the past are forgone.

\subsubsection{The Impact of Austerity}

Some of the impacts of these cuts in program funding and public employment are elaborated on by Bourgeois, Hussey, Saulnier, and Wuite (2012). First off, a negative impact on service quality and accessibility might be witnessed. The quality of the services may suffer as a result of low morale and unmanageable workloads on the part of employees who have not been affected. Furthermore, as direct service delivery is replaced with self-serve options, accessibility issues and marginalization issues may arise. Bourgeois, Hussey, Saulnier, and Wuite (2012, p. 7) makes a statement that the cuts "disproportionately affect Aboriginal Peoples, low-income families and seniors, the unemployed, the environment, workplace and food safety, and Canada's international role." Likewise, existing inequalities may be exacerbated as a result of cost reductions. Again this raises the question of social justice and democratic legitimation tied to austerity measures. 
Another negative characteristic of these cuts comes from downloading federal programs and services. The first points of delegation are the provinces. However, provinces are experiencing their own budget cuts in line with the neo-liberal prescription and the austerity agenda. This leads to further downloading of these programs and services onto municipalities and ultimately families and individuals (Bourgeois, Hussey, Saulnier, and Wuite, 2012). The collective approach of public provisioning is being replaced with the individualistic approach of self-support. This speaks directly to one of the main criticisms of the way the response to the crisis took place - privatize gains and socialize losses. In Polanyi's view, these acts contribute to the deterioration of the social fabric of society and the heavier burden of self-support placed on individuals contributes to cultural alienation, isolation, and depression on the part of those being left behind.

\subsubsection{The Impact of Austerity on Democracy}

Criticism of austerity measures in Canada results in large part from the issue of lack of transparency that surrounded the cuts. Once again, the austerity project demonstrates the disembedded nature of economic relations. This sentiment is best expressed by Bourgeois Bourgeois, Hussey, Saulnier, and Wuite (2012, p. 56, p. 9, p. 9):

"The decisions to cut jobs and services, why, how and where, must be transparent. Reassurances by the government that these cuts will make the public service more effective and efficient, and improve our economy, are lacking evidence.

Stakeholders, including those who rely on the services, as well as those who provide them, must be involved in the decision-making process."

"The federal government should stop implementing job cuts until all information and proper weighing of the costs and benefits of the cuts is provided to Canadians. The decisions about job cuts must involve proper consultation with those providing and managing the services and those using the services, as well as researchers and other stakeholders in the communities affected." 
"The analysis must consider the different kinds of short and long-term impacts cuts might have including on service delivery, quality of service, local/regional economies, unemployment rates, and outmigration."

The Parliamentary Budget Officer (Barkel and Weltman, 2012, p. i) especially criticizes the Budget 2012 reduction measures. The report states:

"The scope, magnitude of measures and related management challenges associated with the Strategic and Operating Review (SOR) announced in Budget 2012 merit careful oversight on the part of parliamentarians. However, the current reporting framework does not provide sufficient information for parliamentarians to fulfill their constitutional obligation to review expenditure management information related to the SOR."

It is further stated by the Parliamentary Budget Officer (Barkel and Weltman, 2012) that reporting available to date is not sufficiently transparent by OECD standards. In order to properly evaluate the cuts and understand their implementation, a baseline must be established for the purposes of comparison. "Despite PBO requests, the government has not provided clear baseline information used for any of the expenditure reduction initiatives in a manner that would allow Parliament to assess impacts on government programs and services (Barkel and Weltman, 2012, p. 3).” As Parliamentarians are the elected officials and ultimately accountable to Canadians, the lack of transparency demonstrated through uncooperative disclosures of information points at a breech in the democratic standing of the country. From a Polanyian perspective, one can deduce that not only did the crisis not generate greater democratic control over the economy, it in fact lessened the little democratic aspect present beforehand. 


\subsection{Conclusion}

By examining the policies and actions undertaken by the federal government in the wake of the economic crisis through the Polanyian lens, this Chapter has clearly demonstrated that government action has been leading to further disembedding of the economy from the democratic socio-political sphere. While some concessions to society were made during the period 2008-11, actions undertaken mainly remained concerned with preserving the dominant forces of the market system. Federal Budgets following the crisis gave concessions such as temporarily prolonged eligibility to Employment Insurance to those directly affected by the unfavourable economic situation. The stimulus plans helped to maintain jobs in critical sectors and to revitalize the economy. Moreover, these actions were decided upon in consultation with society through public consultations.

While the financial system does provide benefits to society in the form of credit arrangements and investment opportunities and a highly developed financial sector increases the size of the economic pie of a country, benefitting the society as a whole, the profits reaped through the propagation of the same economic system are highly concentrated within the hands of capital holders. Although the state imposed some regulations on financial institutions, these regulations were limited and have been dismantled bit by bit. There is no socio-democratic control over the financial system that lies at the core of the crisis. The fact that the post-crisis environment has left financial institutions untouched but attacked public spending demonstrates the depth of disembeddedness. 
Furthermore, the neo-liberal government of Canada headed by Stephen Harper chose to turn on society when it implemented its austerity agenda in later budgets. Austerity measures, which most adversely affect middle and lower social classes, lacked transparency and full disclosure by the state of these measures was not forthcoming. This again points to the strength of the commitment of the federal government to abide by neo-liberal principles, steering the country in the direction of greater deregulation and freedom for the self-regulating market and away from the socio-democratic nature of the welfare state for which Canada has been previously renowned. As was the case with the rise of the market system, the propagation of neo-liberalism is a deliberate action supported by the state. All this points to the continued subordination of society to the perils of the market system, which is strongly backed by state action aligned with neoliberal ideology.

Polanyi's vision of market society under democratic control and embedded in society, in which citizens as opposed to market mechanisms make the ultimate decisions in the functioning of the economy, is not substantiated in the post-crisis environment in Canada. Further disembeddedness better characterizes the state in which the country has found itself in the wake of the global economic crisis of 2008. Nevertheless, as Polanyi predicted, counter forces pushing in the opposite direction towards greater embeddedness are coming to the forefront of the Canadian socio-political landscape. This phenomenon will be elaborated upon in the next Chapter. 


\section{Chapter: Societal Response to Austerity: an Attempt to Re- Embed the Economy within Society}

\subsection{Social Movements' Resistance to Austerity}

Political disorder has been prevalent since the breakout of the crisis in 2008. This is evident in declining turnout at the voting polls, the rise of conservative populist parties such as the Tea Party in the US and neo fascist parties in France, Hungary, Greece and the Ukraine to cite the most prominent examples. Other examples of neo-conservatism include the defeat of the Labour Party in the UK (2010) and Australia (2013), and the rise of conservative parties to power in Germany, Italy, and Scandinavia. At the moment, only South American seems to be a departure from this trend. Focusing specifically on the rise of populist parties in the United States supports Polanyi's notion of perverse social reaction (as was the rise of fascism in Nazi Germany) to the damage caused by an unrestrained market system (Munck, 2010). Colatrella (2011) cites a 'planetary strike wave' by witnessing the working class throughout the industrial world come out and demand justice. According to him, opposition from common citizens poses the biggest obstacle to "realizing the austerity program of global capital (Colatrella, 2011, p. 87)." Colatrella (2011) further expands on major themes prevalent within this strike wave. A first theme is its global presence as people are protesting politico-economic changes in the Middle East, Europe, North and South America. The second theme is the positioning or logistics of demonstrations. Gatherings are taking place at docks, border crossings, post offices, railway crossings, etc., disrupting the world of global commerce. Workers involved in production processes or the supply of raw materials represent a third commonality in global opposition to austerity. And lastly, the protests by government 
workers directly affected by cuts in programs and jobs signify an important commonality among the protesters.

While Canada was "far from the public outrage and popular mobilization that is occurring in Europe and elsewhere (Campbell, 2009, p. 1)", Canadians were not standing idly by in the face of austerity. The first notable demonstration in the wake of the crisis was the G20 protests in Toronto in June 2010. Some 40,000 people protested against the global austerity agenda, as world leaders gathered to discuss the course to be taken henceforth (Ontario Federation of Labour, 2011). 2011 saw the rise of the Occupy Movement, originating on Wall Street in New York City and spreading to a multitude of other countries including Canada. The movement brought thousands onto streets and into public spaces to fight against the prevailing social injustice and inequality in the wake of the crisis. Between February and September of 2012, university students of Quebec gathered to oppose the hikes to tuition fees, with an estimated one third of the student body supporting the cause. The two latter movements will be elaborated on in this Chapter to demonstrate the growth of counter-movements opposing the disembeddedness in Canada. In all of these cases, massive arrests and police brutality were present. "Just as inspiring was the 10,000-strong Toronto demonstration on April 9 in support of public services and against Mayor Rob Ford's austerity agenda. And on September 26, over 8,000 people converged on Toronto City Hall to defend good jobs and public services for the next generation (Ontario Federation of Labour, 2011, p. 20)." Since then, the involvement of the community in opposition to Rob Ford's austerity has grown. But the protests don't stop there. Many members of civil society joined hands in solidarity to show their unification in common cause against the injustices of the response to the 
crisis. Postal workers, teachers, students, seniors, union members, and members of civil society organizations were among the frontlines of resistance in Canada (Ontario Federation of Labour, 2011).

Campbell (2012, p. 248) believes that it is "necessary for progressive people to organize to oppose militarization, defend livelihoods and social security protection, and chart the path towards real and sustainable alternatives".

In Polanyi's perspective, these counter-movements are unlike the deliberate state action of austerity in an effort to solidify neo-liberalism. Rather, they are spontaneous and natural in nature, arising out of the effort to self-preserve and protect from greater deregulation of the market, which ultimately causes devastation for the masses. In the contemporary environment of post-crisis austerity, the Double Movement is inevitable; however, its extent and success is tied to a multitude of factors. Whether the assertions made by the rise of society against disembeddedness translate into political action aimed at protecting society gives an indication of how successful the Double Movement will be at exerting more democratic control over the economy. The following sections will elaborate on the Occupy Movement and the Quebec Students Movement with some regard to their success in moving the pendulum swing towards a more embedded market system in Canada. While the success of these counter-movements is relevant, the main objective of the thesis is to demonstrate the presence of societal reaction in the wake of austerity measures.

\subsubsection{The Occupy Movement}

Amongst other forms of protests against austerity, one movement in particular stood out for the world to see - the Occupy movement. In the summer of 2011, the 
Adbusters publication based out of Vancouver ignited the spark of action and in September a group of peaceful protestors gathered on Wall Street in New York, one of the major centres of international finance:

"On September 17, we want to see 20,000 people flood into lower Manhattan, set up tents, kitchens, peaceful barricades and occupy Wall Street for a few months. Once there, we shall incessantly repeat one simple demand in a plurality of voices. ... we demand that Barack Obama ordain a Presidential Commission tasked with ending the influence money has over our representatives in Washington. It's time for DEMOCRACY NOT CORPORATOCRACY, we're doomed without it (Adbusters, July 13, 2011).

Attracting a high level of media attention, the movement spread quickly to over 1,000 manifestations which were taking place in 87 countries around the globe (Occupy Canada Facebook, Nov 11, 2011).

Occupy was not an isolated movement in history. Since the onset of the crisis, social uprisings have been prevalent throughout the world. Part of Occupy's success was attributed to movements preceding it, and which served to raise awareness of social injustices. Food riots in 2007 and in 2008 that took place in Africa, India and East Asia are one of the first signs of a global fight against the neo-liberal regime. The mass actions taking place since 2010 during the general strikes in Greece and the Spanish indignados also contributed to the rise of Occupy, as did the Arab Spring of 2011 and the ensuing conflicts in many of the Middle Eastern nations (Cobbett and Germain, 2012). The UK's "Uncut" movement opposing austerity measures and highlighting the option of funding public spending through corporate taxation is another example of the roots of Occupy (Bailey, 2012). All of these events are connected; according to Wight (2012, p. 161) "What connects them is a corrupt, degenerative, immoral, sexist, and racist global capitalist political-economic system.” 
The official Occupy Wall Street website embodies the essence of the movement

in two similar presentations:

"Occupy Wall Street is a leaderless resistance movement with people of many colors, genders and political persuasions. The one thing we all have in common is that We Are The 99\% that will no longer tolerate the greed and corruption of the $1 \%$. We are using the revolutionary Arab Spring tactic to achieve our ends and encourage the use of nonviolence to maximize the safety of all participants (Occupywallst.org, 2011)."

"Occupy Wall Street is a people-powered movement that began on September 17, 2011 in Liberty Square in Manhattan's Financial District, and has spread to over 100 cities in the United States and actions in over 1,500 cities globally. \#ows is fighting back against the corrosive power of major banks and multinational corporations over the democratic process, and the role of Wall Street in creating an economic collapse that has caused the greatest recession in generations. The movement is inspired by popular uprisings in Egypt and Tunisia, and aims to fight back against the richest $1 \%$ of people that are writing the rules of an unfair global economy that is foreclosing on our future (Occupywallst.org, 2011)."

With the slogan "We are the 99\%", the Occupy movement embodied a call for social justice and the end of gross inequalities and corporate greed. While the neo-liberal model of the world continues uninterrupted, even after the devastating effects of the 2008 crisis, hardworking people are bearing the brunt of financial greed, corruption and paying the price of the ensuing bailouts (Pickerill and Krinsky, 2012). According to Kilibarda (2012, p. 24), jobs and homes are being lost "in order to secure an economic model that seeks to commodify all social relations in a context of growing global inequality."

Many scholars captured the essence of what the movement is about:

"There is, then, on the one hand a narrowly-defined \#Occupy movement, and on the other hand a more broadly defined movement seeking to challenge - through popular mobilisation, direct action, and/or civil disobedience - the austerity measures that are being introduced in the wake of the post-2007 global economic crisis. In each case, we witness the strategy of occupation as a means of highlighting popular dissatisfaction (Bailey, 2012, p. 138)."

"Now with the Occupy movement and other forms of mobilization in North America I think more and more people think there's something at stake, more 
people feel threatened by the turn our governments are taking towards user-pay systems, fewer and fewer public universal fee services. This affects more and more people, and so there's been some kind of an awakening. I think the Occupy protests in the U.S. last year were the first mass protest in decades - ones before were on specific issues like women's rights, gay rights, race - but now it concerns everyone (Taylor, 2012, p. 7)."

Consensus-based decision-making was employed in running this movement, demonstrating a need to embrace community action. Extra governmental forms of expression were viewed as the necessary means to bring about social justice in the world in which the financial markets runs the state. The Occupy movement challenged the current system of representative democracy by engaging in direct democracy tactics of decision making. The decentralized, horizontal, non-hierarchical nature of participation also characterized the movement as did its grassroots origins (Bailey, 2012). The NYC General Assembly website (2011) sites the principles of solidarity of Occupy:

"Through a direct democratic process, we have come together as individuals and crafted these principles of solidarity, which are points of unity that include but are not limited to:

- Engaging in direct and transparent participatory democracy;

- Exercising personal and collective responsibility;

- Recognizing individuals' inherent privilege and the influence it has on all interactions;

- Empowering one another against all forms of oppression;

- Redefining how labor is valued;

- The sanctity of individual privacy;

- The belief that education is human right; and

- Making technologies, knowledge, and culture open to all to freely access, create, modify, and distribute. (amendment passed by consensus 2/9/2012)"

The movement's lack of concrete demands also allows it to break free of the convention of the current political system.

"By making no demands of the state then, the occupy movements try to evade this risk by refusing to engage the category of the state as the essential space where politics should take place. Instead, they have identified the apparatus of the state as merely one of a number of technologies of power which both discipline 
individuals and solicit sociocultural energies from populations in the context of contemporary capitalism (Kiersey, 2012, p. 158).”

While the demands were not articulated, they were nevertheless present. The biggest demand cited by Adbusters (2011) is the call to awaken the imagination for a future in which democratic forces would shape our society. Other demands articulated by Sitrin (2012) include constraining of the power of corporations, expanding access to healthcare, education, and affordable housing, and discontinuation of austerity measures. Wight (2012, p. 164) states:

"One of the most common criticisms of the Occupy Movement is the lack of a coherent set of demands or a political programme around which the movement might converge. This criticism is misguided. It seems to me that the movement has a very clear idea of what it wants even if this can't be articulated as a particular political programme with a clear end goal."

The tactic to occupy public space utilized in this movement served a particularly important purpose. While this tactic has been used throughout most other social movements, the Occupy Movement turned encampments into the primary site of resistance. These encampments, which acted as autonomous, extra-parliamentary sites ruled by direct democracy, marked the alternative, regardless how farfetched, of what social organization may look like. They challenge the conventional institutionalized norms and limits mandated through politics and law (Pickerill and Krinsky, 2012). Kohn (2013, p. 100) states that "appropriation of space was the most visible aspect of a broader assertion of collective control of the common wealth of society." The movement used unconventional and at times disruptive strategies and tactics to make their occupation be known. Judith Butler attributes occupation of public space to a "continual struggle for and claim over public space (which) is accompanied by a struggle 'over those basic ways 
in which we are, as bodies, supported in the world - a struggle against disenfranchisement, effacement, and abandonment' (Cobbett and Germain, 2012, p. 111)."

As in other movements and protests of the neo-liberal age, excessive use of police violence and brutality was also observed throughout the duration of the Occupy movement. The incident that captured the most attention was intentional herding of protestors by police officers onto the Brooklyn Bridge and the subsequent arrest of over 700 peaceful demonstrators once they were trapped. Police brutality however, resulted in widespread support of the movement (Gitlin, 2013). According to Brown (2012) 62 percent of the population in the United States supported the efforts of Occupy.

In Canada, October 15, 2011 marked the day of action, with occupations spreading to more than 20 cities. Toronto, Montreal, Vancouver, and Ottawa have gathered approximately $3,000,1,000,4,000$, and 700 demonstrators respectively. Frustrated citizens responded to calls for action and marched in solidarity from the spillover effect of Occupy Wall Street. In Toronto, Bay Street represents the city's financial centre, and this was the location of encampments. "The site became a nodal point for marches and demonstrations against economic injustice and, at the height, there were up to 300 campers including an estimated 100 homeless people (Kohn, 2013, p. 100)." Local business owners were quick to oppose the encampments in Toronto. This resulted in police posting evacuation notices in the park on November 14, less than a month from the initial uprising of Occupy in Canada. After objections of eviction from the Occupiers, the Superior Court of Ontario "rejected the claim that the right to free speech and protest entailed a right to camp in public space (Kohn, 2013, p. 100).” The 
occupation was deemed as an attempt to privatize public space. It also claimed that the occupation was anti-democratic as it denied the authority of the state to regulate the use of this public space. Further claims were made in the case of Batty et al vs. the City of Toronto, which proclaimed that the occupiers themselves were excluding the rest of the public from the use of the public space and that a unilateral occupation was used for purely selfish reasons. Despite the peaceful nature of the occupation, the act was deemed illegitimate. Thus, after only 39 days of encampments, those occupying the park voluntarily dissipated prior to being faced with forced eviction and arrests (Kohn, 2013).

A few months later, activists participating in the Occupy movement of Toronto joined the campaign against the municipal budget proposed by Rob Ford, the conservative mayor and a strong supporter of neo-liberal politics. This anti-Ford campaign was in the end able to reverse approximately $\$ 20$ million of proposed budget cuts in the city. Thus, the Occupy movement ignited action in other areas of activisms, especially as it relates to the fight against the neo-liberal austerity agenda. Other organizations in Canada, such as Stop the Cuts and the Ontario Coalition Against Poverty, protesting against austerity measures were hesitant to fully engage with and support the Occupy movement. "Nevertheless, it appeared that the \#occupy encampment in Toronto 'responded really well' to Stop the Cuts. Particularly important were the many people who acted as 'bridges' between \#occupy and existing movements (Kilibarda, 2012, p. 34)." Kilibarda (2012) called the joining of forces between Occupy and other long standing social justice movements as cross-pollination.

The Occupy movement did not come without its share of criticism. The absence of concrete demands at times delegitimized the efforts undertaken by the participants. 
Lack of leadership was also seen as a sign of disorganization, discrediting the efforts being made. Buell (2011) went as far as to say, "broad social transformation probably isn't sustainable if its advocates automatically demonize the concept of leadership." Accusations of exclusion, racism and sexism at the sites of the occupations undermined the message of the united 99 percent fighting against an unjust social system. Moreover, the encampments were said to have created problems of distribution of labour and decision-making power. Kilibarda (2012, p. 31) claims that "participation took on a very oppressive, classist dynamic and reproduced the division between mental and manual labor." Violence at the encampments, reports of sexual harassment towards female participants, and even a tragic death of a young girl from a drug overdose at the Occupy Vancouver site sent messages that contravened the peaceful and democratic nature of the movement (Kilibarda, 2012).

After the evictions of encampments took place with the use of police force, the movement lost its distinctive feature of physical presence, collaboration, and solidarity. Lack of alternatives to the present system also contributed to the fatigue of the movement. Nevertheless, according to Mulqueen and Tataryn (2012, p. 284) the "coming together that formed the Occupy movement will not 'end', since the financial systems that these movements oppose are themselves not disappearing." Here is what Adbusters (Sept 16, 2013) say about the future of the Occupy Movement:

"What we experienced in 2011 is still reverberating around the globe. Most recently, in Turkey and Brazil, that feeling in the guts, that the future does not compute, is vibrant as ever. And because of that gnawing anxiety in the depths of an increasing mass of people, the new mode of activism, what Spanish journalist Bernardo Gutierrez calls a "new architecture of protest," is spreading like a frenzy: what starts out as simple demands - don't cut the trees, don't raise the transit fair, don't institute that corrupt judge - erupts into an all-encompassing desire to reboot the entire machine." 


\subsubsection{The Quebec Student Movement}

Let us now turn to a Canadian born movement putting up a fight against the injustices of the neo-liberal order, the erosion of democratic institutions and the welfare state. Le printemps érable, or the Maple Spring, inspired by the Arab Spring a year earlier, as well as the Occupy movement and the Spanish Indignados, represents the Quebec Student Movement against proposed tuition hikes, against a more general attempt to implement austerity measures throughout the province, and against an even more general social injustice of both the provincial and federal neo-liberal regimes in Canada.

A tuition hike was first announced in 2010 by the Government of Quebec, to be implemented in 2012. The Parti Liberal du Québec (PLQ), with Premier Jean Charest at its head announced a 75 percent increase in university tuition fees over a period of five years, starting in 2012. Over this period, tuition would increase a total of $\$ 1,625$, bringing total fees from $\$ 2,168$ in 2012 to $\$ 3,793$ by 2018 (Sorochan, 2012). While the province of Quebec enjoys one of the lowest tuition fees in North America, the vast majority of Quebec students engaged in protests against the hike. Strong and longstanding traditions of student protests helped create the movement. The "Quiet Revolution" of the early 1960s saw a dramatic change in the approach of post-secondary education in Quebec. The system was revamped and modernized to be more accessible to the French speaking population, with the creation of the CEGEP system and lower tuition fees. The tradition of protection of educational integrity and accessibility continued from then on with student strikes in 1968, 1974, 1978, and 1986, contributing to a freeze in tuition fees for a substantial period of time from 1968 to 1990 . The government succeeded in raising tuition in 1990 despite student protests; however, 
further attempts to do so in 1996 did not materialize as a result of a push-back from students. The strike of 2005 was the last one before the 2012 uprising, somewhat successfully fought off an attempt to convert a substantial amount of grants into loans (Taylor, 2012).

After learning about the hike in 2010, the students of Quebec began protesting, petitioning, and in general opposing the increase. The issue escalated in February of 2012 once the government continuously refused to meet with student representatives to negotiate the terms of the increase. The three major student associations that represented the students of Quebec (FEUQ, FECQ, ASSÉ) voted on a general unlimited strike against the tuition increase. ASSÉ then formed a base for the Coalition Large de l'ASSÉ (CLASSE) which was a temporary and radical coalition representing half of striking students and functioning on the premise of direct democracy to stop the hike of tuition fees. The strike started off with students not attending classes and organizing picket lines around campus grounds, but turned into a wider action to disrupt the economy and draw the attention of the government by blocking highways, bridges, and the metro system, as well as by blockading government buildings, banks, and courthouses. Monthly marches organized on the 22nd day started taking place, with the first taking place on March 22 drawing unprecedented numbers of students and supporters onto the streets of Montreal, with the number of strikers increasing daily. According to Sorochan (2012) April 22 saw approximately 300,000 people join the march. Starting April 25, students begin to assemble nightly to demonstrate across the city of Montreal until the early hours of the morning (Sorochan, 2012). 
In the meantime, riot police were called upon to maintain peace. However, the use of police violence was not justified in the face of relatively peaceful demonstrations with a few incidents of vandalism. According to Sorochan (2012), police were "regularly deployed and chemical weapons, stun grenades, and baton charges are used to break up the crowds". On May 4, police brutality escalated with over 100 arrests being made and 12 people being seriously injured. Sorochan (2012) estimated that a total of 2,500 protestors were arrested during the period of the strike, a number that seems alarmingly high in the context of peaceful demonstrations.

From the side of the government, there was no real effort to meet with student representatives to negotiate the increase of tuition fees. Delegitimizing the movement because of a few broken store fronts was a way for the government to ignore the democratic nature of the protest. The concessions they tried to provide to students (a spread of tuition increase over a seven year period) were insulting. Moreover, the government employed attempts to divide the movement by trying to negotiate separately with the student associations, an attempt that proved to be unsuccessful. While maintaining the airs of willingness to continue to participate in negotiations with the students, the government passes Bill 78 (now Law 12) to curb the movement by practically criminalizing the strike (Sorochan, 2012).

Bill 78 was "designed to suppress peaceful protests and shut down student opposition, while violating the most basic principles of free speech, association and assembly (Giroux, 2012).” It served to suspend the winter 2012 term of institutions disrupted by the strike, banned interruption of classes, criminalized demonstrations of 50 or more people that did not provide their itinerary to the police prior to assembly, 
sanctioned fees paid to student associations, and imposed heavy fines for those in breach of the law. The law not only contravened the Quebec and Canadian Charter of Rights and Freedoms, it was also reprimanded by the Human Rights Council of United Nations (Lamoureux and Racevskis, 2012).

The bill backfired on the government as it was perceived by most Quebecers as an undemocratic attack on human rights and freedoms and a grotesque unfairness towards legitimate demands posed by students. This was a pivotal moment for the movement as the protest was now receiving support by most fractions of society and not just the students.

"An opinion poll conducted by one of Quebec's most respected pollsters found that 78 percent of Quebecers believe the government has "gone too far" and, despite the massive media campaign aimed at depicting the students as violent and selfish, found respondents equally split between those for and against the government's attempt to legislate against the students (Keith, 2012)."

On May 18, the night that Bill 78 passed into law, tens of thousands took to the streets in Montreal in a willful act of civil disobedience. "Manifs casseroles" were the result, representing the nightly banging of pots and pans by citizens across Quebec in a protest against the law.

"Because Law 78 directly attacks all citizens' freedom of association and free expression, large segments of the population that had not previously felt called upon to demonstrate spontaneously pour into the streets, returning evening after evening to demonstrate their displeasure and their commitment to the common good and the fundamental values of democracy, to the accompaniment of banging pots and pans (Bordeleau and Massumi, 2012)."

Democratic spirit and solidarity was shown through this truly spontaneous reaction by a wide range of ordinary people who were standing up to injustice. The "Manifs casseroles" marked the largest act of non-violent civil disobedience in Canada. 
Support was also demonstrated on a smaller scale throughout Canada, the US and Europe (Leblanc, 2012). "Manifs casseroles have been an unexpected occasion for political engagement and resistance by a wide range of everyday people who do not customarily find themselves in the streets objecting to their government (Barney, 2012).” As a result of the law, the May 22 demonstrations saw the participation of over 300,000 people, which is a significant number in a province of 8 million people. The demonstrations continued on a nightly basis on people's front porches and balconies. June and July demonstrations maintained the momentum and gathered large groups of demonstrators despite the summer months. By this time, the movement had transcended student boundaries, and attracted large numbers of supporters from labour unions in and outside of Quebec, opposition party politicians, and many other left-wing organizations speaking out on behalf of civil rights and civil society (Taylor, 2012).

On August 1st, Jean Charest announced an election to take place on September 4th. Student protestors were wary of any election since a change in government might occur replacing the Liberal Party of Quebec with another party equally committed to a neoliberal order. An election would not likely result in a more general overhaul of the neo-liberal order; however, they still hoped for a resolution of the tuition increase issue. The Parti Québécois won a minority government in the election, after being in opposition for three consecutive terms. As was hoped for, students gained a victory with the rollback of tuition increases announced the day following the election (Taylor, 2012).

The student protests did not remain without critics. Milner (2012) states that twothirds of the Quebec population was in support of the increase in tuition fees. The government portrayed students as privileged, spoiled and ungrateful brats. At the same 
time some critics viewed the event as "a narcissistic, collective temper tantrum by whiny students (Giroux, 2012)." These claims were magnified by mainstream media, who sided with the government and made students out as the villains in this struggle for social justice. Disorderly conflict, vandalism, and stories of broken storefronts were blown out of proportion and delegitimized the overall peaceful and democratic nature of the protests. Media consistently reiterated that even with the increase in tuition, Quebec universities would still be the most accessible in Canada in terms of costs (Sorochan, 2012). In terms of opposition to the protests, Milner (2012) voiced his discontent with the turn of events. He brought forth a rationale for why the Quebec education system can never become as cost effective as it is in Scandinavia, and that the province will head towards France's destiny of high levels of debt, unemployment, and deteriorating state institutions if it continues on this path of social services provision.

\subsection{Facebook Content as Expression of Societal Resistance}

The internet and social media has recently become the communication medium of choice for counter-movements in Canada and around the world. Connecting such a great variety of people in an unprecedented way allows communication to flow rapidly with enormous potential for spread and outreach, especially through viral messaging. The medium is particularly popular among youth, but not exclusively since more than half a billion people around the world now have a Facebook account. Social media mobilizes people by informing and inspiring them to bring about change or take action. For the evaluation of the societal response of Canadians to the actions undertaken by the government in the wake of the financial crisis, anti-austerity discourse was derived from 
Facebook pages of Occupy Canada and l'Association pour une Solidarite Syndicale Etudiante (ASSÉ). Large volumes of posts were examined and key posts were used which expressed the general sentiment of those involved on these pages.

\subsubsection{Occupy Movement}

In order to go even deeper into the impact of the societal response embodied through this movement, an exploration of the Occupy Canada official Facebook page ${ }^{3}$ was undertaken. The Facebook page was created on September 25th, 2012, merely a week after Occupy Wall Street set up camp in Zuccoti Park in New York City. In May of 2014, it had 77,196 likes and Facebook analytics revealed a weekly reach through organic sharing of individual posts of close to four million people in May of 2012 (Occupy Canada, May 27, 2012). The page had and continues to have numerous daily posts by Occupy Canada and individuals alike. The general conversation is intellectually stimulating, informative, and revolutionary in nature.

There is a general presence of distrust for the current socio-economic-political system expressed on the page.

"We live in an area where elected politicians ignore the needs of their constituents, where the judiciary and police institutions will not uphold the rights of citizens, where the media is afraid to report the truth, where lawlessness abounds and ordinary people are left unprotected and defenseless against the rapacity of few (Tony Anderson, Oct 30, 2011).”

"Corporate media needs to be occupied (The Movement Canada, Dec 28, 2011)."

"Bankers, big business and corrupt politicians (governments) have worked together to eradicate the middle class worldwide (Occupy Canada, Sept 28, 2011)."

\footnotetext{
${ }^{3}$ All of the excerpts below are found on the Occupy Canada Facebook page (accessed on May 14, 2014).
} 
"Regulation is not the solution. The ethical solution is to remove the government from the market (Tim Perry, Nov 21, 2011)."

"Click "Like" if you're against criminal bankers and corrupt government (Occupy Canada, Dec 24, 2011).”

"Anti-democratic corporate influences are making us dangerously numb to ugly realities, and blind to better alternatives (Occupy Canada, March 27, 2014)."

However, despite the negative perception of the current reality, optimism is

present for what the future may hold and what the movement's role in these changes may be:

"The great thing about Occupy is that more and more people who are upset and frustrated can now not only have a voice but they can get educated about why they are frustrated and they can find out more stuff to get them outright pissed off (Leslie Ann Bowers, Dec 15, 2011)."

"The answer to our dilemma is for people of courage to actively help each other. Only if we unite can we succeed (Tony Port Medway, Oct 30, 2011).”

The Facebook page has numerous posts in a form of calls for action. These calls are inspiring and motivating, instilling a sense that change really is possible. Reminders are made that whatever action is undertaken it should always be peaceful. Below are some of the calls for action and motivating messages associated with Occupy Canada:

"Whose down for a revolution? We are UNSTOPPABLE! Another world is POSSIBLE! (Occupy Canada, Nov 30, 2011)"

"You cannot evict an idea whose time has come (Navid Zamani, Nov 16, 2011)."

"We're finally waking up and dissenting from the capitalist- and governmentpropagated myth that capitalism is a fair socio-economic system (Pooya Esla, Nov 26, 2011)."

"Folks are slowly saying "enough is enough" every day (Doug Macpherson, Dec 15, 2011)."

“WE'RE STILL HERE! WE'LL NEVER BACK DOWN. WE'LL NEVER GIVE UP FIGHTING WITH ALL WE GOT FOR YOU (Occupy Canada, Jan 4, 2013)." 
"If only people knew their true power and took a stand as we're all in this together to shape the future for all generations to come (Occupy Canada, Sept 6, 2013)."

Occupy Canada did not just write about calls for action. Demonstrations were actually organized and executed long after the encampments have been evicted. For example, on January 26, 2014, Occupy Canada partook in a demonstration to support Canada Post workers in their quest to save home mail delivery.

Moreover, the Occupy Canada Facebook page gave, received and continues to see considerable cross-movement support. Other Canadian, North American and international factions of Occupy showed their solidarity by posting on this page. Meanwhile Occupy Canada supported the efforts undertaken by the Quebec Student Movement and the Idle No More Movement, as well as joined the 15,000 protestors voicing their fury against Ontario's Liberal government's austerity-focused budget and Ontario teachers protesting against anti-union attacks by the government.

The issues of social justice, inequality and democracy, which are the pillars of the Occupy Movement worldwide, are discussed to a great extent on the Occupy Canada Facebook page. In terms of inequality, Paula Milheiras (Nov 25, 2011) raised the issue of inequality in taxation, in which corporations and banks are being taxed at proportionately low rates, while the middle class carries most of the burden of taxation. While Suzanne Hall (Nov 16, 2011) asserted that "Occupy has already made a huge difference - the issue of financial inequality is now front and centre of the political discussion." Discussions on the issue of direct democracy were brought to the table and a wide consensus on its benefits was expressed. Lauren Miller (Nov 29, 2011) even proposed that democratic representation should be one of the main demands of the 
Occupy movement. At the same time, discontent about the current political system is expressed. "People are turned off from politics. Who do you vote for when it doesn't matter who gets in? (Aaron Mullin, July 30, 2012)" Mike Hemstalk (May 3, 2013) states that "We need a new political party in Canada to truly represent the $99 \%$."

As the park encampments were repressed and issues concerning the Occupy Movement turned towards more broad discussions concerning the state of Canada, particularly harsh criticism was and continues to be expressed towards Harper's Conservative government and the neo-liberal agenda being pursued. References to Harper as the 'Crime Minister', his disapproval ratings standing at 51 percent (Sept 24, 2012), discussions about election fraud (which was in fact corroborated by federal court), lack of transparency in implementing $\$ 5.2$ billion of budget cuts, dismantling of the health care system through the implementation of $\$ 36$ billion in cuts to federal health funding over 10 years are just some of the examples that Occupy Canada and its participating members brought to the forefront. Occupy Canada quotes Chris Hedges (Nov 9, 2012) expressing that "Harper is sort of a poster child for corporate malfeasance and corporate power, just sort of dismantling everything that's good about Canada."

Despite of the progressive conversation taking place within the confines of the Occupy Canada Facebook page, negativity, criticism, and pessimism towards the movement were also expressed. The major source of this sentiment stems from a lack of concrete actions undertaken by the Movement:

"If the aim is for a successful non-violent revolution then, what needs to be done is eliminate the generalized theories floating around about how this 'could' work and start outlining specific strategies for how it WILL work (Stu Edwards, Nov 30, 2011)." 
"There isn't any discussion of alternatives going on here... why not offer a comprehensive plan as to an alternative to the issues that we as a species are facing (Jesse J. Dainard Smith, Nov 21, 2011).”

"Lots of "we want", lots of "blame", lots of "finer pointing" AND no proposed solutions (Dianne Beaman, Nov 22, 2011)."

"No one is clear on what to do...besides complain and protest (Lana Joe Salant, Dec 26, 2011)."

Renato G. Di Lorenzo (Oct 31, 2011) claimed that the Canadian version of the movement is just a 'jump on the band wagon sympathy movement' and proclaimed the Americanization of Canadian politics. The leaderlessness of the movement created friction: "If you want this movement to succeed then take responsibility for it and lead the way (Chuck Faubert, Nov 29, 2011)." And a general absence of changes instills pessimism expressed by Michelle Stright-Foto (Dec 26, 2011) “I don’t [think] things have changed much yet. It may have gotten plenty of attention but we need far more action...The $99 \%$ is still struggling."

\subsubsection{Quebec Student Movement}

Association pour une Solidarite Syndicale Etudiante (ASSÉ) “is a union-type organization that brings together, across Quebec, more than 70,000 members in several student associations at both colleges and universities." With more than 16,000 likes, the Facebook page of this organization was one of the main social media platforms for the Quebec Student Movement. The page aimed to spread knowledge about latest developments within the movement, latest demonstrations, changes in actions of the government and legislation, and searched for ideas of how to best disseminate information and demonstrate. More strongly than the Occupy Canada page, the ASSÉ 
Facebook page ${ }^{4}$ represents a conversation about neo-liberalism and austerity and the burdens it places on average citizens of Canada.

On the Facebook page, there is a strong sentiment expressed on a continuous basis of the unfairness of the way services to Canadians are being dismantled through neoliberal policies of both the provincial and federal governments.

"Since when do economics decide who can and can't have access to knowledge? (Clara Rourou, Nov 6, 2012)"

"A tuition hike is not a matter of isolated accounting, but the goal of a neoliberal austerity agenda the world over. Forcing students to pay more and more for education is part of a transfer of wealth from the poor and middle-class to the rich - as with privatization and the states withdrawal from service-provision, tax breaks for corporations and deep cuts to social programs (Vincent el Mejor, May 2, 2012)."

The example of England's increase in tuition fees affecting university attendance by a drop of 15 percent was used to show what happens when social services are dismantled (ASSÉ, Nov 6, 2012). Frustration over increases in fees in other areas of life in Quebec is also expressed. For example, hydro fees, fees for driving permits, gas prices are all going up, and Old Age Security benefits were pushed to 67 years from 65 . While frustration exists, not much action is being undertaken on that front; whereas the mobilization of the students, for whom tuition fees are of high importance, is able to break free from the consenting paradigm and fight for their rights.

\footnotetext{
${ }^{4}$ All of the excerpts below are found on the ASSÉ Facebook page (accessed on May 17, 2014). The translation from French to English was complete using Google Translate and from the writer's personal knowledge of the language.
} 
A negative sentiment was expressed in regards to the Liberal government of

Quebec. While the student organizations were ready to negotiate with the government, reciprocity was not present.

"All scenes of confrontation which we are currently witnessing, they are caused by the minister, because it is she who refuses to engage in dialogue with us.... The violence, it is the direct result of the attitude of this government (ASSÉ Apr 13, 2012)."

"The objective of the government is to break the student movement and use this conflict as a springboard for re-election (ASSÉ, Apr 26, 2012).”

"I am disgusted by the attitudes of Charest, Beauchamp, and Dutil... I say to our youth : courage, determination, solidarity, and justice, justice will always triumph in our democracy... in the long-term.... I am 100\% with you (Buddy McdeLaval, Apr 27, 2012)."

"PQ, PLQ, CAQ : are at the service of the rich and the fascists! (Jolie Minois, July 20, 2012)"

ASSÉ used the Facebook page to mobilize students for action. Among examples

of this is the following post:

"March 22, April 22, and May 22 we attended three of the greatest events in the history of Quebec. We want to continue in this sense and to call on the population to join students on June 22 and July 22 (ASSÉ, June 4, 2012).”

Not only did ASSÉ mobilize using social media, the Facebook page also drew a tremendous amount of support from both the student body and the general public:

"I love it... united people, will never be conquered!!! (Titi Tete de Livre, June 20, 2012)"

"I am proud of the youth of Quebec! (Philippe Simonnot, June 4, 2012)"

"You have awoken QUEBEC don't give up (Mario Joly, June 4, 2012)."

The Facebook page also drew inspiration by celebrating the victories achieved by the movement. Among the achievements are the facts that the movement became the longest and largest student strike in North America and the largest act of civil 
disobedience in Canada, and that most importantly its success in the reversal of the decision to increase tuition fees.

"As announced, the increase in tuition fees and Act 12 are repealed after 6 months of fighting. We have blocked the increase, and not to be mistaken - if there is victory, it is the historical movement of the spring. It is March 22 to May 22 to July 22. It is the casserole demonstrations and direct actions of the month of April. It is the hundreds of thousands of students on the picket lines (ASSÉ, Sept 20, 2012).”

"The extraordinary student mobilization in Quebec has already sustained the longest and largest student strike in the history of North America, and it has already organized the single biggest act of civil disobedience in Canadian history. It is now rapidly growing into one of the most powerful and inventive antiausterity campaigns anywhere in the world (quote from Guardian UK, ASSÉ, June 1, 2012)."

Not all Facebook posts however were supportive in nature. The Quebec Student

Movement experienced a lot of negativity stemming from the rest of society and the amount of discouraging posts on the ASSE page attests to this notion. The students are often referred to as spoiled brats that are walking around with their iPhones and iPads but are unwilling to pay a few hundred dollars more for the valuable education they are receiving. Some of the derogatory posts are quoted below:

"Well look everyone knows that the poor are cannon fodders and don't have dreams or aspirations (Véronique Bouillard, Nov 6, 2012)."

"Hey gang of BSers, if you would like free education, go serve in the army. At the same time it will serve to break your little characters of royal children (Jack Mathers, May 2, 2012)."

\subsection{Embeddedness: Analysis of Societal Resistance, 2011-2014}

\subsubsection{The Occupy Movement}

The Occupy Movement made great progress in highlighting a decline in the legitimacy of institutions affecting our economic, social, and political lives. As per the 
Ontario Federation of Labour (2011), this decline contributed to the assault on unionized and public sector workers, seniors, welfare recipients, and the electorate as a whole. Ordinary citizens continued to forgo their rights in the face of neo-liberal policies that benefited the rich and drove the wedge of inequality ever deeper. Polanyi's concern for social justice resonates all throughout the Occupy Movement. This is particularly alarming when the vast majority of the population of both America and Canada believe in a system of progressive taxation and segregation of finance from politics. According to the Polanyian perspective, the movement is fighting for state actions to take into account the general interest of society in its decision making process. While the current dominant forces are swaying state actions towards the propagation of the neo-liberal system of deregulation, this Double Movement is fighting for the provisions of basic human needs, health, and education that accord freedom and dignity, that are being harshly attacked by the austerity agenda. The Occupy Movement's resistance to further deregulation of the market system and its continuous disembeddedness from society demonstrated ordinary citizens' desire to bring economic forces under socio-democratic control and exposed the counter-movement nature of this phenomenon.

In Polanyi's thought the stark utopia of the self-regulating market system is incompatible with democracy. The self-regulating market delegitimizes democratic forces of society and allows for more authoritarian measures to be taken. The Occupy movement proclaimed a battle against the rise of authoritarian neo-liberalism and attempted to reclaim democratic citizenship. The crisis and the ensuing austerity measures were viewed as a direct result of a lack of democracy. Through its engagement in direct democracy, the Occupy movement expanded the democratic spaces, giving rise 
to new voices, ideas, and alternatives to the prevailing social order. Sitrin $(2012$, p. 74$)$ claims that "their purpose is not to determine "the" path that a particular country should take but to create the space for a conversation in which all can participate and in which all can determine together what the future should look like.”

The slogan "We Are the 99\%" was very powerful in capturing the attention of average citizens who could relate to the struggle being fought. It brought to attention the skewed system of our society in which conditions for those in the upper echelons of wealth were getting progressively better, especially with the introduction of tax cuts; whereas the conditions of the majority of the population were either stagnant or declining largely due to the deterioration of the welfare state. While globalization and increased financialization is creating unprecedented amounts of growth and wealth, it does not get redistributed among working and middle classes. This is a key part of the social injustice experienced by many and questioned by the Occupy movement. Polanyi is a proponent of redistribution as he links it to social justice and the ultimate freedom to live in dignity and realize human potential. Kiersey (2012, p. 157) states, "the burden of debt that the $99 \%$ must endure merely to maintain a dignified standard of living bespeaks the erosion of any semblance of democracy in the allocation of social wealth." At the same time, the slogan is criticized for its lack of recognition of diversification within the $99 \%$. The discourse is said to overlook social hierarchies of gender, class, race, etc. This criticism likewise largely applies to the works of Karl Polanyi, who employs the concept of holism and totality when contemplating society as opposed to focusing on multiple factions within society. Nevertheless the powerful slogan serves to capture the imagination of 
ordinary citizens and bring to their attention the injustices stemming from a growing divide between the 'haves' and the 'have-nots'.

The closures of encampments and the lack of alternatives and concrete actions to undertake could be interpreted as a failure of the Double Movement. However, it is not the outcome but the process of uprising that is most important in classifying Occupy as a counter-movement. The discourse about capitalism and democracy was brought to the forefront of attention in both the United States and Canada, contributing to the strengthening of civil society and raising awareness to the injustices of the socio-politicoeconomic system. Owsley $(2012$, p. 1) examined the Occupy Movement through a Polanyian perspective and concluded that "the movement's substantive success in imposing social constraints on markets was limited, but that it successfully created a new socially-oriented political-economic dialogue.” The author (Owsley, 2012, p. 25) argues that Occupy is in fact a counter-movement:

"The analysis of participants' motivations for engaging in Occupy, and the desires for change that the movement represented, produced a number of central themes. The movement rejects financial markets in their current form, rejects the lack of institutional support for individuals in the labour market, and rejects the current form of representative politics. These themes distinctly indicate the movement's desire to re-embed the economy within a democratic institutional framework."

The interaction of ordinary citizens on the Occupy Canada Facebook page provides a number of indications that speak to the success of the Occupy Movement in resisting the continued disembeddedness. The sheer volumes of interaction are an important indicator. In May of 2012, nearly four million unique people have seen content from the Occupy Canada page in one week through organic sharing of the Facebook posts. Assuming these are all Canadians, this means that in a country of 33 million people, more than 10 percent of the population was participating in this 
information sharing and spread of ideas geared towards re-embeddedness. The diverse topics discussed on the page indicate the start of conversations that were not taking place prior to the economic crisis and the rise of the movement. As the veil of economic growth and prosperity was wiped away by the crisis, many ordinary people were awoken to the realities of the disembedded socio-economic system. Dissatisfaction with the political regime in Canada is present in great volumes on the page; however, while negative sentiments are expressed, Harper's Conservatives won a majority government in the 2012 election. Despite this setback, the New Democratic Party, Canada's national social democratic party, gained the place of official opposition for the first time in Canadian history. This was largely due an unexpected breakthrough in Quebec, the site of the student protest. This aspect could serve as an indication that the rise of sociodemocratic sentiment was taking place with the rise of ideas embodied by the Occupy movement. Another important indicator of a successful resistance to disembeddedness is the fact that demonstrations continued to take place even after the encampments were dismantled and the Occupy Canada movement supported other protests speaking out against austerity. An argument could be made that the Occupy movement in Canada was an inspiration for movements that took place in its wake and that were actually successful in obtaining their demands and thus contributed to a form of re-embeddedness on a much smaller scale. The anti-Ford movement and the Quebec Student Movement are examples of triumphant actions putting a stop to further disembeddedness in terms of Toronto budget cuts and Quebec university tuition fees. The future of the Occupy movement will not unfortunately be found in local parks and in the streets of local financial districts; it 
will however flourish though its integration in other civil society organizations throughout communities.

Despite the absence of concrete success of the Occupy movement in reembedding the economy within the sphere of societal influence, this resistance is still

considered to be a counter-movement. While the movement may not contribute greatly to the re-embeddedness, it nevertheless served to resist further disembeddedness. As the movement still resonates through society in Canada, further successes may be possible. According to Polanyi, as long as the neo-liberal agenda is being perpetuated, through austerity measures or otherwise, counter-movements will inevitably rise to exert selfprotection of society from the stark utopia of the self-regulating market system.

\subsubsection{Quebec Student Movement}

What grounds for protest did the 2012 Quebec Student Movement have? First and foremost the movement was fighting against the "commodification of education, the financialization of student life and the privatization of the university (Giroux, 2012)." But it actually goes beyond the premise of education and is a fight against the neo-liberal view of the organization of society. The neo-liberal conception of education idealized by the Charest government "sees education as a private good that provides symbolic and material advantages to individuals (Lamoureux and Racevskis, 2012)." On the other hand, the concept of education widely held by the Quebec student protestors is that of a "public service that makes possible the formation of social and intergenerational solidarity, benefitting society as a whole and facilitating the individual's entry into the labor market as well as the realm of citizenship (Lamoureux and Racevskis, 2012).” This contention is taking place when Canada's student debt has reached $\$ 20$ billion or $\$ 27,000$ 
per year, curtailing the future of students before they even start off in the workforce (Giroux, 2012). This fight against the commodification of aspects of human life strongly resonates with Polanyian thought. Public funds that could be provided for investment in higher education, get redistributed to other government priorities such as 'tough on crime' policies, prison expansions, and funding for the military.

Barney (2012) sees the strike as a class struggle against the ruling elite with the minority representing the interests of the capital imposing austerity measures on the majority (middle and lower classes). In a classic portrayal of Polanyi's Double Movement, the protests were fighting against a broader movement of austerity aimed at dismantling the public nature of government services and implementing pricing strategies on a per-user basis. According to Camfield (2012) the Charest government wanted to revamp Quebec's cultural opposition to neo-liberal principles. The author (Camfield, 2012) said of the Charest government that "It wants to replace the belief that people have a right to access public services funded by progressive taxation with the principle of "user pay."' Giroux (2012) brings to our attention the importance of the struggle of the students of Quebec:

"Now a major broad-based opposition movement against neoliberal austerity measures, the Quebec student strike initiated one of the most powerful, collectively organized challenges to neoliberal ideology, policy and governance that has occurred globally in some time."

One could say that Quebec already enjoys a more embedded socio-economic system than the rest of Canada. This may lead to the belief that attempts at disembedding the economic sphere from social relations won't generate a great response by society as embeddedness still prevails. Quite the opposite is true. The students in Quebec rose to protect their social rights despite the insignificant nature in face value of the increase in 
tuition. The criticism towards students that the increase in tuition fees is relatively insignificant ignored the fact that "students viewed the tuition increase as only one symptom of an ailing and unjust social order about which they could no longer be silent (Giroux, 2012).” The Quebec Student Movement goes beyond the increase of tuition, but aims at bringing more justice into the society faced by constant attacks on social protection crucial to the well-being of many. Likewise, the negative sentiments expressed towards the movement on the ASSÉ Facebook page provide an indication that neo-liberal principles are strongly entrenched in our society, even in Quebec which is considered to be the most socio-democratic province in Canada.

The implementation of Bill 78 and the rise of 'manifs casseroles' was a demonstration of the strength of the Double Movement. With such drastic measures taken by the state to support the self-regulating market, society spontaneously reacted in a proportionally similar dramatic outbreak of civil disobedience. Polanyi believed that some form of counter-movement would be inevitable but what he could not predict was what specifically would provoke protest and the nature and extent of protest. However, Polanyi did believe that as long as the state sides with market forces and threatens the social fabric of its citizens, outbursts of self-protection will be prevalent. The deployment of police to suppress the protest and the employment of such an undemocratic measure as Bill 78 to it, together signify the extent to which disembeddedness is present in our society. The state sided so strongly with the dominating forces of the market system that it was willing to employ violent means and undemocratic restrictions on its citizens to ensure the propagation of the system. 
Winning the fight over the increase of tuition fees is a strong indicator that societal forces are in fact strong enough to re-embed economic relations under the democratic control of society. While this represents a small victory in the grand scheme of the retrenchment of the welfare state in Canada, it is nevertheless an attainment on the part of social forces.

Besides reaching the general goal of curbing the tuition hike, the Quebec Student Movement went beyond the issue of education, and showed potential in acting as a precursor to an even greater mobilization geared at transforming the society we live in and perhaps re-embedding the economy within the realm of society. These student activists may go on to become involved in unions and politics in a way that would allow for the flourishing of success in future social struggles. According to Rashi (2012), the Quebec Student Movement was a spark for a wider battle yet to come. This is expressed in the following quotes:

"This remarkable movement has politicized Quebec society around the question of neoliberalism in a way that is without precedent in the Canadian state. It has radicalized many people, especially youth, many of whom have gained very valuable experience in mass mobilization and democratic self-organization (Camfield, 2012).”

"At stake in their efforts is not only a protest against tuition hikes, austerity measures, joblessness and cuts in public spending, but also the awakening of a revolutionary ideal in the service of a new society. Unapologetic in its implementation of austerity measures that cause massive amounts of hardship and human suffering, neoliberal capitalism consolidates class power on the backs of young people, workers and others marginalized by class, race and ethnicity (Giroux, 2012)."

"By engaging in a social strike, the Quebec protesters have reopened history, articulated a call for collective and shared struggles and made visible those groups who are increasingly ignored or viewed as disposable. ...protesters have demonstrated a degree of courage, skill, organization and solidarity that will not easily fade away. A revolutionary idea has been born and now waits for the 
conditions through which it can become a more powerful, inspiring political and moral force (Giroux, 2012).”

\subsection{Conclusion}

Castles, Cubas, Kim, Koleth, Ozkul and Williamson (2011, p. 16) provide an insight into why the evaluation of social movements in the contemporary times of neoliberalism is so important and where to look for alternatives:

"Contemporary counter-movements will, in all likelihood, not lead to a revival of post- World War settlement and social contract, because the world has indeed gone through a great transformation since the collapse of socialism and the acceleration of capitalist globalisation. Undoubtedly, new global social modes of regulation will emerge. What is certain is that Polanyi, as a precursor of the theory of radical democracy, would be looking to ordinary people for democratic alternatives to current forms of globalization."

Both the Occupy Movement and the Quebec Student Movement represent contemporary counter-movements to the continued actions of the government which contribute to further disembeddedness of the economy from the sphere of societal influence. The Quebec Student Movement had a successful outcome in reverting government decisions, while the Occupy Movement, with a lack of concrete demands, did not attain the same concrete goals it aimed for. Despite this divergence, and despite the limited nature of success of re-embedding the economic factors within society, the counter-movements are still considered to be successful. Their success lies in the willingness of society to stand up in the face of injustice and proclaim demands of a world in which socio-democratic forces have more say and power. As Castles, Cubas, Kim, Koleth, Ozkul and Williamson mention, the revival of a welfare state is likely not possible; what is possible however is a greater degree of exertion of socio-democratic principles in the political decisions of governments in Canada. While the reembeddedness of which Polanyi theorized has not fully occurred, the Occupy Movement 
and the Quebec Student Movements might have been successful in preventing a further swing of the pendulum towards greater disembeddedness expressed through post-crisis austerity measures. 


\section{Chapter: Conclusion}

This thesis examined the contemporary situation in Canada's post-global economic crisis environment of actions on the part of the state on the one hand and the societal response to those actions on the other. This was accomplished using Karl Polanyi's theoretical framework of the Double Movement and its associated concepts of the pendular swing from embeddedness to disembeddedness of the economic forces from those of society.

The first proposition of the thesis, in terms of actions undertaken by the government, is that the economic crisis has been the occasion for and accompanied by state policies and actions geared towards further disembedding of the Canadian economy from society. The state's financial support to financial institutions, the stimulus package, and the ensuing austerity measures all produce evidence that the neo-liberal regime in Canada is not being overthrown in the wake of the crisis, but is in fact perpetuated and further entrenched. The evidence for state action presented in Chapter 3 was gathered through the federal Budgets, which outlined (in some cases with more transparency than others) the measures undertaken to handle the aftermath of the crisis. While according to some experts Canada weathered out the economic meltdown fairly well, the impact of a recession was nevertheless felt. Corporate losses were estimated at 42 percent, while the count of full time job losses was estimated at over 400,000. As a reaction to the crisis, the financial sector was provided with financial support of close to $\$ 300$ billion, and the economy benefited from $\$ 45$ billion of federal funding as part of the stimulus package known as the Economic Action Plan, which included $\$ 9.2$ billion of support to GM, Ford 
and Chrysler car manufacturers and $\$ 6.2$ billion of tax relief. Some concessions were provided to middle and lower classes of society in the period of 2008 to 2011 , such as prolonged eligibility to Employment Insurance following the economic crisis and the stimulus plans directed towards maintaining jobs in critical sectors and revitalizing the economy. Nevertheless, state action served to mostly benefit the financial and corporate sectors through tax cuts, financial support to financial institutions, lack of reprimands and regulatory controls placed on the source of the crisis, and the systematic transfer of wealth from the public to the private spheres.

What followed the financial support to financial institutions and stimulus were austerity measures aimed at curtailing public expenditures. Strategic Reviews generated $\$ 11$ billion of public cuts over seven years starting in 2007 and another $\$ 2.8$ billion of ongoing cuts. The Deficit Reduction Action Plan cut an additional \$5.2 billion in ongoing expenditures. Public sector employment was officially reduced by 19,200 jobs through Budget 2012. Coupled with hiring freezes of previous Budgets and an estimated impact cuts in expenditures had on private sector employment, that number rose to 70,000. Austerity measures that concentrated on reductions of public spending and elimination of public sector jobs, affecting middle and lower classes in great proportion, point to the distortion in the root cause of the crisis (financial sector) and the solution chosen to return to status quo (scaling back of the public sector). Lower and average income earners, as well as the elderly, the unemployed and Aboriginal peoples felt a greater impact of the cuts to government programs, declining service standards, and the increase in eligibility age for Old Age Security benefits starting in 2023. Moreover, economic activity was negatively impacted by the cuts to public sector jobs, especially 
when the cuts are as high as 8 percent of all federal employment. The commitment of the state to the principle of neo-liberalism is witnessed, causing the country to strive for greater deregulation and freedom for the self-regulating market and to turn away from the socio-democratic nature of the welfare state for which Canada has been renowned around the world in previous decades. From Polanyi's perspective, the evidence strongly supports the fact that disembeddedness is being systematically perpetuated in Canada, while the vision of market society under democratic control and embedded in society is falling further from reach in the contemporary post-crisis environment.

According to the theory of the Double Movement, greater disembeddedness on the side of economic forces leads to a spontaneous reaction on the side of society aimed at bringing the economy back under the sphere of societal influence, which is embodied in the second proposition of the thesis. This proposition states that there are social movements taking shape in Canada and globally in reaction to the disembedding of the economy in a variety of forms. Such counter-movements can be expressed through social protest and attempts to build an alternative economy to better serve people through cooperative forms of activity. In Canada, examples of social movements towards greater embeddedness were expressed through the Occupy Movement, which originated on Wall Street in New York City in September of 2011 and fought against corporate greed and inequality, uniting the 99\%; and the Quebec Student Movement, which took to the streets in February of 2012 and protested a 75 percent increase in university tuition fees in Quebec. These protests embody the anti-austerity discourse of the contemporary postcrisis situation in Canada. The internet and social media are the new catalysts in bringing about mobilization and awareness. As the analysis of Facebook posts representing these 
movements has demonstrated, ideas of social justice and a fight against growing inequality and concessions to the corporate sector at the expense of labour, that were not previously mainstream, have now entered our consciousness.

While we have not witnessed the re-embeddedness to the degree Polanyi has described, the counter-movements have been successful in their own right. The Occupy Movement brought the much needed awareness to the social injustice of the neo-liberal regime and spilled over into other anti-austerity protests such as the anti-Ford campaign in Toronto. In the case of the Quebec Student Movement, the proposed increases to tuition fees were withdrawn by the government. On the other hand, some may argue that the Occupy Movement had very limited success, withered out fairly quickly apart from its continuous web presence, and did not serve as a spark of a wider social protest. The Quebec Student Movement was also limited in building coalitions among students in Quebec but not across the country. These results stem from the high level of entrenchment of neo-liberalism in the lives of Canadians. For many, the crisis was a devastating experience, and the desire to return to the status quo was much stronger than looking at root causes and implementing changes to the current system. Quebec sociodemocratic traditions do not translate well to other provinces and this was in part evident in the election of 2011 where the NDP gained the spot of official opposition as a result of strong support from Quebec and the Conservatives won the majority as a result of supporters from Ontario and the Western provinces. The high level of neo-liberal entrenchment in Canada and around the world prevents the pendular swing from leading to greater embeddedness in the present moment; nevertheless, the evidence gathered from 
the Occupy and the Quebec Student Movements does suggest that counter-movements may still serve as a spark to changes in attitudes towards the neo-liberal discourse.

The evidence discussed in this thesis points to the fact that Polanyi's concept of commodification, embeddedness, economic fallacy and stark utopia, as well as freedom and democracy are applicable in the context at hand. Furthermore, the analysis conducted in this work demonstrates the relevance of Polanyi's thought in contemporary examinations of the politico-socio-economic environment and the prevalence of the pendular swing of the Double Movement in a post-crisis period in Canada. While an 'overthrow' of neo-liberalism has not been achieved in this context, and while the pendular swing back towards embeddedness has not moved by much, actions on the part of civil society still point to progressive social forces that appear when the market is given more control over the lives of human beings. To date the degree to which market deregulation and neo-liberal principles are being implemented has not brought a proportionate social reaction within society. Nevertheless, the effects of the social movements to date have had significant impact, leading to a potential change in societal attitudes towards neo-liberalism and a possible future change in direction from market oriented policies to more sustainable welfare state provisions. 


\section{Bibliography or References}

Ankarloo, D. (2002). Some notes on the economic theories of Karl Polanyi. Polanyian Perspectives on Instituted Economic Processes, Development and Transformation. Retrieved from http://nx.a77web.it/index.php?option=com_docman\&task=doc_view\&gid=57

Arsenault, J-F. and Sharpe, A. (2009). The economic crisis through the lens of economic well-being. CSLS Research Reports 2009-06. Centre for the Study of Living Standards, 1-22.

Association pour une Solidarité Syndicale Étudiante. Facebook. Retrieved Extracted May 17, 2014, from https://www.facebook.com/asse.solidarite

Atlantic Council. (2012). The finance crisis: Lessons learned from Canada and the way forward. Washington, DC: Embassy of Canada.

"Austerity." Oxford Dictionaries. Retrieved May 30, 2014, from http://www.oxforddictionaries.com/definition/english/austerity

Bailey, D. J. (2012). \# Occupy: strategic dilemmas, lessons learned? Journal of Critical Globalisation Studies, 5, 138-142.

Barkel, E. and Weltman, P. (2012). Budget and expenditure reporting to Parliament: Strengthening transparency and oversight in an era of fiscal consolidation. Retrieved from the Office of the Parliamentary Budget Officer website: http://www.pbo-dpb.gc.ca/en/

Barkel, E., Jacques, J. and Stanton, J. (2012). Budget 2012: Monitoring framework update. Retrieved from the Office of the Parliamentary Budget Officer website: http://www.pbo-dpb.gc.ca/en/

Barney, D. (2012). The truth of le printemps érables. Theory \& Event, 15.3.

Battle, K. (1998). Transformation: Canadian social policy since 1985. Social Policy \& Administration, 32.4, 321-340. 
Baum, G. (1996). Karl Polanyi on ethics and economics. Montreal, Canada: McGillQueen's Press-MQUP.

Beckert, J. (2009). The great transformation of embeddedness: Karl Polanyi and the new economic sociology. In C.M. Hann and K. Hart (Eds.), Market and society: the great transformation today. Cambridge: Cambridge University Press.

Behiels, M. D. (2010). Stephen Harper's rise to power: Will his "new" Conservative Party become Canada's "natural governing party" of the twenty-first century? American Review of Canadian Studies, 40.1, 118-145.

The birth of neoliberalism: New brooms: How three Viennese thinkers changed the world. The Economist. Retrieved on October 13, 2012, from http://www.economist.com/node/21564533

Block, F. and Somers, M. R. (1984). Beyond the economistic fallacy: the holistic social science of Karl Polanyi. In T. Skocpol (Ed.) Vision and Method in Historical Sociology (pp. 47-84). Cambridge: Cambridge University Press.

Block, F. (2008). Polanyi's double movement and the reconstruction of critical theory. Papers in Political Economy, 38, 2-11.

Bordeleau, É. and Massumi, B. (2012). A first intuition: The strange force of the Québécois spring. Theory \& Event, 15.3.

Bourgeois, M., Hussey, J., Saulnier, C. and Wuite, S. (2012). Public disservice: The impact of federal government job cuts in Atlantic Canada. Canadian Centre for Policy Alternatives.

Brown, W. (2011). Occupy Wall Street: Return of a repressed res-publica. Theory \& Event, 14.4 .

Buell, J. (2011). Occupy Wall Street's democratic challenge. Theory \& Event, 14.4.

Camfield, D. (2012). Quebec's red square movement. The Bullet, 680. 
Campbell, B. (2009). The global economic crisis and its Canadian dimension. Canadian Centre for Policy Alternatives.

Campbell, H. (2012). A response to austerity measures requires audacity not timidity. Souls, 14.3-4, 240-264.

Castles, S., Cubas, M. A., Kim, C., Koleth, E., Ozkul, D. and Williamson, R. (2011). Karl Polanyi's Great Transformation as a framework for understanding neo-liberal globalisation. Consultado a., 9.20, 2-19.

Chaves, E. (2012). Reconciliation or bust? Journal of Critical Globalisation Studies, 117120.

Clarke, H. D., Scotto, T. J. and Kornberg A. (2011). Valence politics and economic crisis: Electoral choice in Canada 2008. Electoral Studies, 30.3, 438-449.

Cobbett, E. and Germain, R. (2012). 'Occupy Wall Street' and IPE: Insights and implications. Journal of Critical Globalisation Studies, 5, 110-113.

Colatrella, S. (2011). In our hands is placed a power: Austerity, worldwide strike wave, and the crisis of global governance. Socialism and Democracy, 25.3, 82-106.

The Conference Board of Canada. (2014) Canadian income inequality: Is Canada becoming more unequal? Retrieved from http://www.conferenceboard.ca/hcp/hottopics/caninequality.aspx

Crotty, J. and Epstein, G. (1996). In defence of capital controls. Socialist Register, 32.32.

Dale, G. (2012). Double movements and pendular forces: Polanyian perspectives on the neoliberal age. Current Sociology, 60.1, 3-27.

Dale, G. (2010). Social democracy, embeddedness and decommodification: On the conceptual innovations and intellectual affiliations of Karl Polanyi. New Political Economy, 15.3, 369-393.

Da Silva, S. (2009). Bank bailouts and the 2009 federal budget. In Financial Meltdown: Canada, the Economic Crisis and Political Struggle, Socialist Project, 41-47. 
Department of Finance. (February 26, 2008). Responsible leadership for uncertain times (Budget 2008). Retrieved from http://www.fin.gc.ca/fin-eng.asp

Department of Finance. (January 27, 2009). Canada's economic action plan (Budget 2009). Retrieved from http://www.fin.gc.ca/fin-eng.asp

Department of Finance. (March 4, 2010). Leading the way on jobs and growth (Budget 2010). Retrieved from http://www.fin.gc.ca/fin-eng.asp

Department of Finance. (June 6, 2011). The next phase of Canada's economic action plan: A low-tax plan for jobs and growth (Budget 2011). Retrieved from http://www.fin.gc.ca/fin-eng.asp

Department of Finance. (March 2012). The stimulus phase of Canada's economic action plan: final report to Canadians (Budget 2012). Retrieved from http://www.fin.gc.ca/fin-eng.asp

Department of Finance. (March 2012). Jobs growth and long-term prosperity: Economic action plan 2012. Retrieved from http://www.fin.gc.ca/fin-eng.asp

Department of Finance. (March 21, 2013). Jobs growth and long-term prosperity (Budget 2013). Retrieved from http://www.fin.gc.ca/fin-eng.asp

Department of Finance. (October 2013). Fiscal reference tables. Retrieved from http://www.fin.gc.ca/fin-eng.asp

Dobbin, M. (May 24, 2010). The Canadian 'good banks' myth. Rabble.ca. Retrieved from http://rabble.ca/blogs/bloggers/alex/2010/05/canadian-good-banks-myth

Filip, B. (2012). Polanyi and Hayek on freedom, the state, and economics. International Journal of Political Economy, 41.4, 69-87.

Giroux, H. A. (August 28, 2012). Days of rage: The Quebec student protest movement and the new social awakening. Truthout. Retrieved from http://truthout.org/opinion/item/11040-the-quebec-student-protest-movement-and-thepower-of-the-radical-imagination 
Gitlin, T. (2013). Occupy's predicament: The moment and the prospects for the movement. The British Journal of Sociology, 64.1, 3-25.

Graham, J. R., Swift, K. and Delaney, R. (2012). Canadian social policy: An introduction, Fourth edition. Don Mills: Pearson Education Canada.

Guest, D. and University of British Columbia. (1997). The emergence of social security in Canada. Vancouver: UBC press.

Hann, C. M. and Hart, K. (2009). Introduction: Learning from Polanyi 1. In C. M. Hann and K. Hart (Eds.), Market and society: the great transformation today. Cambridge: Cambridge University Press.

Harvey, D. (2005). A brief history of neoliberalism. Oxford University Press.

Herman, D. (2012). The missing movement: A Polanyian analysis of pre-crisis America. International Journal of Social Economics, 39.8, 624-641.

Inayatullah, N. and Blaney, D. L. (1999). Towards an ethnological IPE: Karl Polanyi's double critique of capitalism. Millennium-Journal of International Studies, 28.2, 311-340.

Jones, D. S. (2012). Masters of the universe: Hayek, Friedman, and the birth of neoliberal politics. Princeton: Princeton University Press.

Jones, K. (24 May 2012). Quebec student strike: Police begin to apply draconian Bill 78. Global Research: Centre for Research on Globalization. Retrieved from http://www.globalresearch.ca/quebec-student-strike-police-begin-to-applydraconian-bill-78/31029

Kiersey, N. J. (2012). Occupy Wall Street as immanent critique: Why IR theory needs a 'mic check!' Journal of Critical Globalization Studies, 5, 157-160.

Kiladze, T., Perkins, T., Robertson, G., ... and Keenan, G. (September 14, 2013). The 2008 Financial Crisis: Through the eyes of some major players. The Globe and Mail. Retrieved from http://www.theglobeandmail.com/report-on-business/the-2008- 
financial-crisis-through-the-eyes-of-some-major-

players/article14322993/?page $=$ all

Kilibarda, K. (2012). Lessons from \#Occupy in Canada: Contesting space, settler consciousness and erasures within the 99\%. Journal of Critical Globalisation Studies, 5, 24-41.

Kim, W. (2010). Polanyi's Double Movement and Neoliberalization in Korea and Japan. Social Movement Studies, 9.4, 373-392.

Lamoureux, D. and Racevskis, K. (2012). The student strike: A revealing social indicator. Theory \& Event, 15.3 .

Leacy, F. H., Urquhart, M. C. and Buckley K. (Eds.) (1983). Historical statistics of Canada. Ottawa: Statistics Canada.

Leblanc, J. (2012). Bill 78 and the Quebec student strike. Canada Dimension, 46.5, 37.

Loan not backed by even a fender. (March 6, 2009). National Post. Retrieved from http://www.nationalpost.com/story.html?id=8b724b75-0224-4766-a31e$\underline{\text { 5aadeb663eef\&k }=59454}$

Macdonald, D. (2013). The fog finally clears: The job and services impact of federal austerity. Canadian Centre for Policy Alternatives, 1-10.

Mahnkopf, B. (2012). The euro crisis: German politics of blame and austerity - A neoliberal nightmare. International Critical Thought, 2.4, 472-485.

Mayer-Foulkes, D. A. (2009). Long-term fundamentals of the 2008 economic crisis. Global Economy Journal, 9.4.

Mehra, N. (2012). Falling behind: Ontario's backslide into widening inequality, growing poverty and cuts to social programs. Ontario Common Front, 5-41.

Milke, M. (May 31, 2013). Canada's auto bailout: Still waiting for payback. Financial Post. Retrieved from http://opinion.financialpost.com/2013/05/31/canadas-autobailout-still-waiting-for-payback/ 
Milner, H. (2012). Scandinavia or France?: Where does the Quebec Student Strike lead? Inroads, 31, 69-70.

Munck, R. (2010). Globalization, crisis and social transformation: a view from the south. Globalizations, 7.1-2, 235-246.

Murray, J. G., Erridge, A. and Rimmer, N. (2012). International lessons on austerity strategy. International Journal of Public Sector Management, 25.4, 248-259.

National accounts at a glance: Compensation of employees paid by government, percentage of GDP. OECD Statistics. Retrieved on June 12, 2014, from http://www.oecd.org/statistics/

\#Occupy. (2011-2014). Adbusters. Retrieved on May 10, 2014, from https://www.adbusters.org/campaigns/occupywallstreet

Occupy Canada. Facebook. Retrieved on May 14, 2014, from https://www.facebook.com/OccupyCanada

OccupyWallStreet.org. (2011). Retrieved on May 10, 2014, from http://occupywallst.org/about/

Palacios, J. J. (2001). Globalisation's double movement: Societal responses to market expansion in the 21st century. Eighth Karl Polanyi International Conference, Universidad Nacional Automoma de Mexico, Mexico City.

Panitch, L. and Gindin, S. (2009). The current crisis: a socialist perspective. Studies in Political Economy, 83, 7-31.

Pickerill, J. and Krinsky, J. (2012). Why does Occupy matter? Social Movement Studies, 11.3-4, 279-287.

Pitruzzello, S. (2004). Trade globalization, economic performance, and social protection: Nineteenth-century british laissez-faire and post-World War II US-embedded liberalism. International Organization, 58, 705-744. 
Polanyi, Karl. (2001). The great transformation: The political and economic origins of our time. Boston: Beacon Press.

Polanyi-Levitt, K. (2006). Keynes and Polanyi: the 1920s and the 1990s. Review of International Political Economy, 13.1, 152-177.

Polanyi-Levitt, K. (2012). The power of ideas: Keynes, Hayek, and Polanyi. International Journal of Political Economy, 41.4, 5-15.

Principles of Solidarity. (2011). \# Occupy Wall Street NYC General Assembly. Retrieved from http://www.nycga.net/resources/documents/principles-of-solidarity/

Rashi, R. (2009) Canada's big five: Banking on the crisis? In Financial Meltdown: Canada, the Economic Crisis and Political Struggle, Socialist Project, 38-40.

Rashi, R. (2012). The Quebec student movement at the forefront of the fight against austerity. Canadian Dimension, 10.

Rehman, S. S. (2010) The Obama administration and the US financial crisis. Global Economy Journal, 10.1.

Roberge, I. (2010). Explaining Canadian resilience to the global financial crisis: The role of policy networks. Department of Political Science, Glendon College, York University, 2-17.

Robotham, D. (2009). Afterword: Learning from Polanyi 2. In C. M. Hann and K. Hart (Eds.), Market and society: the great transformation today. Cambridge: Cambridge University Press.

Roubini, N. (2009). Warning: more doom ahead. Foreign Policy, 170, 63-64.

Sandbrook, R. (2011). Polanyi and post-neoliberalism in the global south: Dilemmas of re-embedding the economy. New Political Economy, 16.4, 415-443.

Seccareccia, M. (2012). Critique of current neoliberalism from a Polanyian perspective: Politics, philosophy, and economics. International Journal of Political Economy, 41.4, 3-4. 
Silver, B. J. and Arrighi, G. (2003). Polanyi's "double movement": The belle époques of British and US hegemony compared. Politics \& Society, 31.2, 325-355.

Sitrin, M. (2012). Horizontalism and the Occupy movements. Dissent, 59.2, 74-75.

Sorochan, C. (2012) The Québec student strike: A chronology. Theory \& Event, 15.3.

Stiglitz, J. (2009). Capitalist fools. Vanity Fair. Retrieved from http://www.vanityfair.com/magazine/2009/01/stiglitz200901

Strain, F. J. (2007). Debts paid and debts owed: The legacy of Mulroney's economic policies. In R.B. Blake (Ed.), Transforming the nation: Canada and Brian Mulroney. McGill-Queen's Press-MQUP.

Streeck, W. (2011). The crises of democratic capitalism. New Left Review, 71, 5-29.

Taibbi, M. (2009). The great American bubble machine. Rolling Stone. Retrieved from http://www.rollingstone.com/politics/news/the-great-american-bubble-machine$\underline{20100405}$

Taylor, N. (2012). The escalation of tactics: Organizing strategies in the Quebec student strikes and the 'Maple Spring' protests. Social Policy, 42.3, 7-15.

Thomasberger, C. (2012). The belief in economic determinism, neoliberalism, and the significance of Polanyi's contribution in the twenty-first century. International Journal of Political Economy, 41.4, 16-33.

Tyson, L. (2012). The wrong austerity cure. Project Syndicate. Retrieved from http://www.project-syndicate.org/commentary/the-wrong-austerity-cure

Valderrama, P. (2012). Planning for freedom. International Journal of Political Economy, 41.4, 88-105.

Veneroso, F. and Wade, R. (1998). The gathering world slump and the battle over capital controls. New Left Review, 231, 13-42. 
Vrasti, W. (2012). Mic check / reality check. Journal of Critical Globalisation Studies, 121-126.

Williamson, J. (1990). What Washington means by policy reform. Latin American adjustment: How much has happened, 7, 7-20.

Wolf, M. (2007). Unfettered finance is fast reshaping the global economy. Financial Times. Retrieved from http://www.ft.com/cms/s/2/518482b4-1dc5-11dc-89f7000b5df10621.html\#axzz3Ck8XVqoM 